\title{
In Silico Prediction of Steroids and Triterpenoids as Potential Regulators of Lipid Metabolism
}

\author{
Valery M. Dembitsky
}

check for updates

Citation: Dembitsky, V.M. In Silico Prediction of Steroids and

Triterpenoids as Potential Regulators of Lipid Metabolism. Mar. Drugs 2021, 19, 650. https://doi.org/10.3390/ md19110650

Received: 25 October 2021

Accepted: 19 November 2021

Published: 22 November 2021

Publisher's Note: MDPI stays neutral with regard to jurisdictional claims in published maps and institutional affiliations.

Copyright: (C) 2021 by the author. Licensee MDPI, Basel, Switzerland. This article is an open access article distributed under the terms and conditions of the Creative Commons Attribution (CC BY) license (https:// creativecommons.org/licenses/by/ $4.0 /)$.
Centre for Applied Research, Innovation and Entrepreneurship, Lethbridge College, 3000 College Drive South, Lethbridge, AB T1K 1L6, Canada; valery.dembitsky@lethbridgecollege.ca; Fax: +1-888-858-8517

\begin{abstract}
This review focuses on a rare group of steroids and triterpenoids that share common properties as regulators of lipid metabolism. This group of compounds is divided by the type of chemical structure, and they represent: aromatic steroids, steroid phosphate esters, highly oxygenated steroids such as steroid endoperoxides and hydroperoxides, $\alpha, \beta$-epoxy steroids, and secosteroids. In addition, subgroups of carbon-bridged steroids, neo steroids, miscellaneous steroids, as well as synthetic steroids containing heteroatoms S (epithio steroids), Se (selena steroids), Te (tellura steroids), and At (astatosteroids) were presented. Natural steroids and triterpenoids have been found and identified from various sources such as marine sponges, soft corals, starfish, and other marine invertebrates. In addition, this group of rare lipids is found in fungi, fungal endophytes, and plants. The pharmacological profile of the presented steroids and triterpenoids was determined using the well-known computer program PASS, which is currently available online for all interested scientists and pharmacologists and is currently used by research teams from more than 130 countries of the world. Our attention has been focused on the biological activities of steroids and triterpenoids associated with the regulation of cholesterol metabolism and related processes such as anti-hyperlipoproteinemic activity, as well as the treatment of atherosclerosis, lipoprotein disorders, or inhibitors of cholesterol synthesis. In addition, individual steroids and triterpenoids were identified that demonstrated rare or unique biological activities such as treating neurodegenerative diseases, Alzheimer's, and Parkinson's diseases with a high degree of certainty over 95 percent. For individual steroids or triterpenoids or a group of compounds, 3D drawings of their predicted biological activities are presented.
\end{abstract}

Keywords: steroids; triterpenoids; hormones; regulators; lipid metabolism; activity

\section{Introduction}

Lipids are a complex name for many metabolites of natural origin, and they are combined into various groups according to a common physical property, hydrophobicity, that is, insolubility in water [1-4]. However, this definition is currently not entirely correct, since some groups, phospholipids or sphingolipids and some others, manifest themselves as amphiphilic compounds; that is, they can dissolve both in polar substances and in non-polar solvents [5-8].

Lipids play an important role in the body in storing energy and are components of biological membranes, steroid hormones, bile acids, and vitamins. They come from food or de novo synthesis in the liver. Fatty acids, stored primarily as triglycerides, are the main source of energy for the muscles and heart. However, the overproduction and accumulation of triglycerides in adipose tissue and other tissues are closely associated with metabolic disorders in humans. Disorders of lipid metabolism lead to the development of many diseases, including atherosclerosis, which occurs because of a violation of cholesterol homeostasis and is closely associated with atherosclerosis [9,10]. In addition, estrogen and estrogen receptors are well-known regulators of several aspects of metabolism, including glucose and lipid metabolism, and impairment of estrogen signaling is associated with the development of metabolic diseases [11]. 
The regulation of lipid metabolism is of interest primarily in the context of the regulation of energy flow and the way of its integration with other energy sources in tissues. A special role in the regulation of lipid metabolism is played by hormones such as adrenaline and norepinephrine, glucagon, glucocorticoids, hormones of the anterior pituitary gland, as well as thyroxine and sex hormones [12-20].

This review is devoted to natural, semi-synthetic and synthetic steroids, and triterpenoids isolated from plants, fungi, marine invertebrates, and synthesized in various laboratories around the world. The presented class of molecules differs from many other steroids or triterpenoids that exhibit a wide range of biological activities aimed at lowering cholesterol by inhibiting cholesterol synthesis or other activities associated with these processes.

\section{Aromatic Steroids Derived from Natural Sources}

The most famous natural monoaromatic steroids that are of some practical interest in terms of regulators of lipid metabolism are estrone (1), estradiol (2), estriol (3), and equilin (4). The chemical structures of these aromatic steroids are shown in Figure 1. It is known that estrone is a minor female sex hormone, which was discovered in the 1920s from the urine of pregnant women independently by two groups of scientists from Germany and the United States, biochemist Adolph Butenandt and American scientists Edward Doisy and Edgar Allen, respectively [21-28]. Later, Adolf Frederik Johann Butenandt from the Institute of Chemistry in Götting (Germany) received the Nobel Prize in Chemistry in 1939 for the discovery of this hormone.

Estrone, or (8R,9S,13S,14S)-3-hydroxy-13-methyl-7,8,9,11,12,14,15,16-octahydro-6Hcyclopenta[a]phenanthren-17-one (1), is produced in vivo from androstenedione and/or testosterone via estradiol. The above-mentioned estrogens show estrogenic activity with various variations $[29,30]$, although changes in the structure of estrogens D ring may also demonstrate anticancer activity [31]. The presence of female sex hormonal (1-4) estrogens was first detected in plants in 1926 by Dohrn and co-workers [32] and then, in the 1930s, simultaneously by Butenandt and Jacobi [26] and Skarzynski [33]. Recently, Janeczko and Skoczowski [34] published a survey in which they summarized the data on the presence of mammalian sex hormones and their physiological role in plants. These hormones, such as 3,17 $\beta$-dihydroxy-1,3,5(10)-estratriene, rosterone, testosterone, or progesterone, were present in $60-80 \%$ of the plant species investigated. Butenandt and Jacobi [26] isolated estrone (1) from seeds and pollen of Hyphaene thebaica, Glossostemon bruguieri. Glycyrrhiza glabra, Malus pumila, Phoenix dactylifera, Ph. vulgaris, Punica granatum, Salix caprea, and Salix sp. The chemical structures of steroids and triterpenoids are shown in Figure 1, and biological activity is shown in Table 1.

From the 1930s to the present, more than 15,000 articles have been devoted to various issues of estrone and its derivatives, and more than 200 reviews summarize the data on the activity of this hormone. Estrone (1) and estradiol (2) and their derivatives (3-10) are the main natural estrogens found in humans and are involved in estrogen metabolism [35-38]. Endogenous estrogens in humans demonstrate a wide range of biological activities and are involved in the regulation of lipid metabolism, which has been the subject of tens of thousands of articles, reviews, and books. Additionally, in this short paragraph, we will not list and discuss this topic, but in Table 1, we give a short list of the main biological activities that aromatic steroids show. 


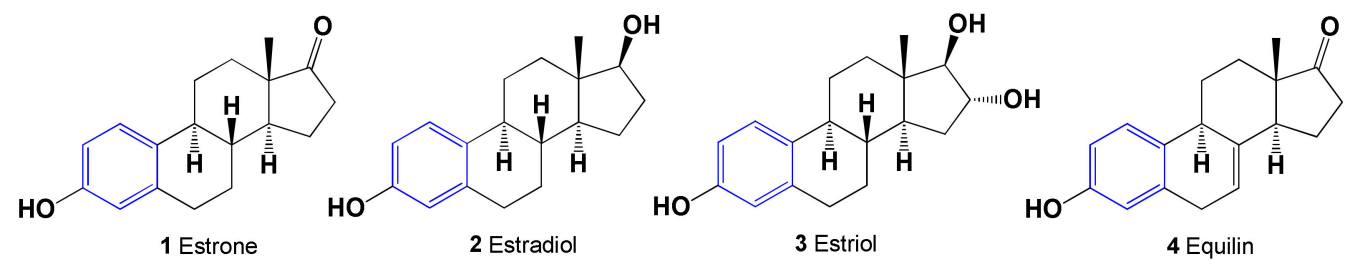

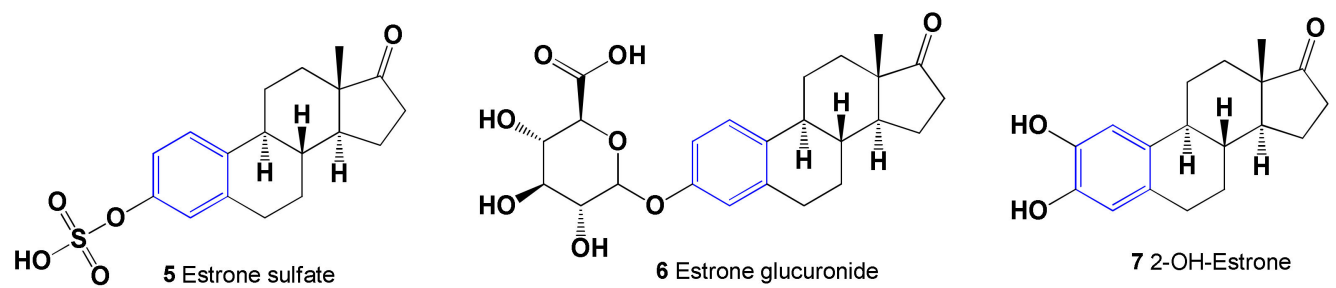<smiles>C[C@]12CC[C@@H]3c4ccc(O)c(O)c4CC[C@H]3[C@@H]1CCC2=O</smiles><smiles>COc1cc2c(cc1O)CC[C@@H]1[C@@H]2CC[C@]2(C)C(=O)CC[C@@H]12</smiles>

O 
antidiabetic, wound healing, anti-inflammatory, anticancer, antimicrobial, hepatoprotective, and antioxidant activities [43]. Unusual withanolide (20S,22R)-1,6ß,17 $\alpha, 27$-tetrahydroxy19norwitha-1,3,5(10),24-tetraenolide, named jaborosalactone 7-(12), was isolated from the leaf extracts of Juborosa leucotricha [44].

The steroid 24,26-cyclo-19-norcholesta-1,3,5(10),22-tetraen-3-ol (13) is characterized by the presence of an aromatic A ring containing a cyclopropane ring in the side chain was isolated from the Hainan soft coral Dendronephthya studeri [45]. The ring A-aromatic bile acid 3-hydroxy-19-norchola-1,3,5(10),22-tetraen-24-oic acid (14) was isolated from methanol extract of the marine sponge Sollasella moretonensis, collected from the seabed of northern Queensland, Australia [46]. Commenting on the release of this unusual lipid, the authors point out that aromatic steroids are more typical for plants and less so for marine invertebrates or higher animals. A 4-hydroxy-6-oxopregnane-3-glycoside with an aromatic ring A containing the sugar $6^{\prime}$-deoxy-L- $\beta$-altropyranose- $4^{\prime}$-acetate named hapaioside (15) was found in the extract of a Pohnpei, a tube sponge, Cribrochalina olemda from the family Niphatidae [47]. The activity of this glycoside has not been determined, although it is known that this marine sponge contains cyclic peptides called kapakahines, some of which show cytotoxicity against P388 murine leukemia cells [48]. Structurally similar to hapaioside, 3-(4-O-acetyl-6-deoxy- $\beta$-galactopyranosyloxy)-19-norpregna-1,3,5(10),20tetraene (16) was isolated from bush coral Alcyonium gracillimum (syn. Scleronephthya gracillimum), which was collected from the Gulf of Sagami, Japan [49].

Monoaromatic B ring steroids are rare natural lipids found predominantly in the mushroom kingdom and are also present in marine sediments or oils. Thus, phycomysterol A (17) and C (18), which possess a unusual natural 19-norergostane skeleton with an aromatic B ring, are synthesized by a filamentous fungus Phycomyces blakesleeanus (order Mucorales, the phylum Zygomycota) [50]. In addition, phycomysterol A showed antiviral inhibition at a concentration of $0.64 \mu \mathrm{g}$ per well $(200 \mu \mathrm{L})$ and showed $\left(\mathrm{IC}_{50}=5.0 \mu \mathrm{g} / \mathrm{mL}\right)$ against both mouse lymphomas $\left(\mathrm{IC}_{50}=10 \mu \mathrm{g} / \mathrm{mL}\right.$ ) and against the three human cell lines, A549 (lung carcinoma), HT29 (colon carcinoma), and MEL28 (melanoma) human cell lines.

Pathogenic fungus Gibberella zeae (syn. Fusarium roseum) is a worldwide parasite that can produce a wide variety of steroids and synthesized unusual $(22 E, 24 R)-1(10 \rightarrow 6)$ abeoergosta-5,7,9,22-tetraen-3 $\alpha$-ol (19), which was isolated from the cultures of Gibberella $z e a e$, an endophytic fungus isolated from the marine green alga Codium fragile [51]. This compound showed significant cytotoxicity toward murine colorectal CT26 and human leukemia K562 cancer cell lines. An aromatic B ring called topsentisterol E1 (20) was isolated from bioactive fractions of a marine sponge Topsentia sp. [52]. The presence of this unusual steroid may indicate that it is synthesized by the endophytic fungus, which is a symbiont in this sponge species.

\section{Comparison of Biological Activities of Natural Aromatic Steroids}

It is known that the chemical structure of both natural and synthetic molecules predetermines biological activity, which makes it possible to analyze the structure-activity relationships (SAR). This idea was first proposed by Brown and Fraser more than 150 years ago, in 1868 [53], although, according to other sources, SAR originates from the field of toxicology, according to which Cros in 1863 determined the relationship between the toxicity of primary aliphatic alcohols and their solubility in water [54]. More than 30 years later, Richet in 1893 [55], Meyer in 1899 [56], and Overton in 1901 [57] separately found a linear correlation between lipophilicity and biological effects. By 1935, Hammett $[58,59]$ presented a method of accounting for the effect of substituents on reaction mechanisms using an equation that considered two parameters, namely the substituent constant and the reaction constant. Complementing Hammett's model, Taft proposed in 1956 an approach for separating the polar, steric, and resonance effects of substituents in aliphatic compounds [60]. Combining all previous developments, Hansch and Fujita laid out the mechanistic basis for the development of the QSAR method [61], and the linear Hansch 
equation and Hammett's electronic constants are detailed in the book by Hansch and Leo published in 1995 [62].

Some well-known computer programs can, with some degree of reliability, estimate the pharmacological activity of organic molecules isolated from natural sources or synthesized compounds [63-65]. It is known that classical SAR methods are based on the analysis of (quantitative) structure-activity relationships for one or more biological activities using organic compounds belonging to the same chemical series as the training set [66].

The computer program PASS, which has been continuously updating and improving for the past thirty years [67], is based on the analysis of a heterogeneous training set included information about more than 1.3 million known biologically active compounds with data on ca. 10,000 biological activities [68,69]. Chemical descriptors implemented in PASS, which reflect the peculiarities of ligand-target interactions and original realization of the Bayesian approach for 18 elucidations of structure-activity relationships, provide the average accuracy and predictivity for several thousand biological activities equal to about $96 \%$ [70]. In several comparative studies, it was shown that PASS outperforms in predictivity some other recently developed methods for estimation of biological activity profiles [71,72]. Freely available via the Internet, the PASS Online web service [73] is used by more than thirty thousand researchers from almost a hundred countries to determine the most promising biological activities for both natural and synthetic compounds [74-76]. To reveal the hidden pharmacological potential of the natural substances, we have successfully been using PASS for the past fifteen years [77-80].

Table 1. Biological activities of aromatic steroids with over $90 \%$ confidence.

\begin{tabular}{|c|c|c|c|}
\hline No. & Discovered Activity, $(\mathrm{Pa})$ * & Reported Activity & References \\
\hline 1 & $\begin{array}{c}\text { Ovulation inhibitor }(0.942) \\
\text { Cardiovascular analeptic }(0.924) \\
\text { Antihypercholesterolemic }(0.871) \\
\text { Lipid metabolism regulator }(0.730)\end{array}$ & $\begin{array}{l}\text { Inhibitor aromatase } \\
\text { Sulfatase inhibitor } \\
\text { Estrogenic } \\
\text { Promotor breast cancer }\end{array}$ & [81-84] \\
\hline 2 & $\begin{array}{c}\text { Antihypercholesterolemic }(0.904) \\
\text { Ovulation inhibitor }(0.889) \\
\text { Neuroprotector }(0.870) \\
\text { Anesthetic general }(0.868) \\
\text { Acute neurologic disorders treatment } \\
\text { (0.793) } \\
\text { Prostate disorders treatment }(0.729) \\
\text { Anti-inflammatory }(0.713)\end{array}$ & $\begin{array}{c}\text { Antioxidant } \\
\text { Anti-inflammatory } \\
\text { Uterotrophic } \\
\text { RNA polymerase } \\
\text { Promoter of breast, ovarian } \\
\text { and endometrial cancers } \\
\text { Neuroprotective properties }\end{array}$ & {$[81,85-87]$} \\
\hline 3 & $\begin{array}{c}\text { Ovulation inhibitor }(0.900) \\
\text { Acute neurologic disorders treatment } \\
(0.822) \\
\text { Antihypercholesterolemic }(0.791)\end{array}$ & $\begin{array}{l}\text { Estrogenic } \\
\text { Agonist of the ERs } \\
\text { RNA polymerase }\end{array}$ & {$[88,89]$} \\
\hline 4 & $\begin{array}{l}\text { Antihypercholesterolemic }(0.856) \\
\text { Ovulation inhibitor }(0.847) \\
\text { Cardiovascular analeptic }(0.842) \\
\text { Lipid metabolism regulator }(0.788)\end{array}$ & $\begin{array}{c}\text { Estrogenic } \\
\text { Estrogen agonist }\end{array}$ & [90-92] \\
\hline 5 & $\begin{array}{c}\text { Acute neurologic disorders treatment } \\
(0.912) \\
\text { Male reproductive disfunction treatment } \\
(0.847) \\
\text { Ovulation inhibitor }(0.786) \\
\text { Postmenopausal disorders treatment } \\
(0.643) \\
\text { Antihypercholesterolemic }(0.640) \\
\text { Menopausal disorders treatment }(0.579)\end{array}$ & $\begin{array}{c}\text { Inhibitor aromatase } \\
\text { Sulfatase inhibitor } \\
\text { Inhibitor of human breast } \\
\text { cancer } \\
\text { Concentration } \\
\text { Cardiovascular agent } \\
\text { Postmenopausal disorders }\end{array}$ & {$[93,94]$} \\
\hline 6 & $\begin{array}{c}\text { Antihypercholesterolemic }(0.973) \\
\text { Acute neurologic disorders treatment } \\
(0.922) \\
\text { Lipid metabolism regulator }(0.907) \\
\text { Antithrombotic }(0.714) \\
\text { Ovulation inhibitor }(0.662) \\
\text { Dementia treatment }(0.616) \\
\text { Hypolipemic }(0.613) \\
\text { Male reproductive disfunction treatment } \\
(0.587) \\
\text { Menopausal disorders treatment }(0.582)\end{array}$ & $\begin{array}{l}\text { Estrogenic } \\
\text { Ovarian activity } \\
\text { Urine production }\end{array}$ & [95] \\
\hline
\end{tabular}


Table 1. Cont.

\begin{tabular}{|c|c|c|c|}
\hline No. & Discovered Activity, $(\mathbf{P a}) *$ & Reported Activity & References \\
\hline 7 & $\begin{array}{c}\text { Ovulation inhibitor }(0.956) \\
\text { Cardiovascular analeptic }(0.927) \\
\text { Antihypercholesterolemic }(0.868) \\
\text { Male reproductive disfunction treatment } \\
(0.847) \\
\text { Menopausal disorders treatment }(0.842) \\
\text { Acute neurologic disorders treatment } \\
(0.745) \\
\text { Lipid metabolism regulator }(0.701) \\
\text { Menstruation disorders treatment }(0.639) \\
\text { Postmenopausal disorders treatment } \\
(0.605) \\
\text { Muscular dystrophy treatment }(0.601) \\
\text { Contraceptive female }(0.570) \\
\text { Anti-infertility, female }(0.567)\end{array}$ & $\begin{array}{c}\text { Estrogenic } \\
\text { Antiestrogenic effects } \\
\text { Anticancer }\end{array}$ & [96-98] \\
\hline 8 & $\begin{array}{c}\text { Ovulation inhibitor }(0.930) \\
\text { Cardiovascular analeptic }(0.925) \\
\text { Antihypercholesterolemic }(0.855) \\
\text { Male reproductive disfunction treatment } \\
(0.843) \\
\text { Acute neurologic disorders treatment } \\
(0.780) \\
\text { Menopausal disorders treatment }(0.747) \\
\text { Lipid metabolism regulator }(0.601) \\
\text { Muscular dystrophy treatment }(0.579) \\
\text { Postmenopausal disorders treatment } \\
(0.561) \\
\text { Menstruation disorders treatment }(0.533)\end{array}$ & $\begin{array}{c}\text { Estrogenic } \\
\text { Strongest neuroprotective } \\
\text { effect } \\
\text { UDP-glucuronosyltransferase } \\
\text { Anti-breast cancer }\end{array}$ & [99-101] \\
\hline 9 & $\begin{array}{c}\text { Ovulation inhibitor }(0.953) \\
\text { Cardiovascular analeptic }(0.928) \\
\text { Antihypercholesterolemic }(0.857) \\
\text { Menopausal disorders treatment }(0.807) \\
\text { Male reproductive disfunction treatment } \\
(0.805) \\
\text { Acute neurologic disorders treatment } \\
(0.660) \\
\text { Contraceptive }(0.655) \\
\text { Lipid metabolism regulator }(0.645) \\
\text { Contraceptive female }(0.558) \\
\text { Menstruation disorders treatment }(0.542) \\
\text { Anti-infertility, female }(0.503) \\
\text { Postmenopausal disorders treatment } \\
(0.500)\end{array}$ & $\begin{array}{c}\text { Antioxidant } \\
\text { Estrogenic } \\
\text { Anti-breast cancer }\end{array}$ & [102] \\
\hline 10 & $\begin{array}{c}\text { Ovulation inhibitor }(0.925) \\
\text { Cardiovascular analeptic }(0.922) \\
\text { Antihypercholesterolemic }(0.833) \\
\text { Male reproductive disfunction treatment } \\
(0.821) \\
\text { Menopausal disorders treatment }(0.712) \\
\text { Acute neurologic disorders treatment } \\
(0.662) \\
\text { Contraceptive }(0.602) \\
\text { Lipid metabolism regulator }(0.571) \\
\text { Muscular dystrophy treatment }(0.548)\end{array}$ & $\begin{array}{c}\text { Estrogenic } \\
\text { Proliferation of human breast } \\
\text { cancer }\end{array}$ & [103-105] \\
\hline 11 & $\begin{array}{c}\text { Antihypercholesterolemic (0.959) } \\
\text { Hypolipemic }(0.808)\end{array}$ & Activity not studied & \\
\hline 12 & $\begin{array}{l}\text { Lipid metabolism regulator }(0.913) \\
\text { Antihypercholesterolemic }(0.767)\end{array}$ & Activity not studied & \\
\hline 13 & $\begin{array}{c}\text { Antihypercholesterolemic }(0.961) \\
\text { Hypolipemic }(0.711)\end{array}$ & Activity not studied & \\
\hline 14 & Antihypercholesterolemic (0.953) & Activity not studied & \\
\hline 15 & Antihypercholesterolemic (0.946) & Activity not studied & \\
\hline 16 & Antihypercholesterolemic (0.907) & Activity not studied & \\
\hline 17 & Antihypercholesterolemic (0.929) & Activity not studied & \\
\hline 18 & Antihypercholesterolemic (0.935) & Activity not studied & \\
\hline 19 & Antihypercholesterolemic (0.950) & Activity not studied & \\
\hline 20 & Antihypercholesterolemic (0.914) & Anticancer & [52] \\
\hline
\end{tabular}

* Only activities with $\mathrm{Pa}>0.5$ are shown.

In the current study, we obtained PASS predictions for about one hundred steroids and triterpenoids produced by different living organisms. PASS estimates are presented as 
Pa values, which correspond to the probability of belonging to a class of "actives" for each predicted biological activity. The higher the Pa value is, the higher the confidence that the experiment will confirm the predicted biological activity [78,80].

The study of the biological activity of aromatic steroids using the PASS program showed that all steroids presented in Table 1 can be divided into two groups. The first group includes steroids that show antiovulation activity with a high degree of reliability, and the second group includes steroids for which antihypercholesterolemic activity is dominant. The first group includes aromatic steroids numbered $7, \mathbf{9}, \mathbf{1}, \mathbf{8}$, and 10 with over 92.5 percent confidence, although the second group includes steroids $\mathbf{6}, \mathbf{1 1}, \mathbf{1 3}, \mathbf{1 4}, \mathbf{1 5}$, and 19 with over 94.6 percent confidence, according to PASS.

A 3D graph of the predicted and calculated activities of aromatic steroids belonging to the first group is shown in Figure 2. From the first group of steroids that are inhibitors of ovulation, 2-hydroxyestrone (7) can be distinguished, which has a confidence level of more than 95\%, and its predicted activities are presented in Figure 3. Additionally, 3D graphs that demonstrate the predicted pharmacological activity were obtained using the Origin Pro 2021 graphical program. The program analyzes the data obtained by the PASS program and builds graphs that are given in this publication.

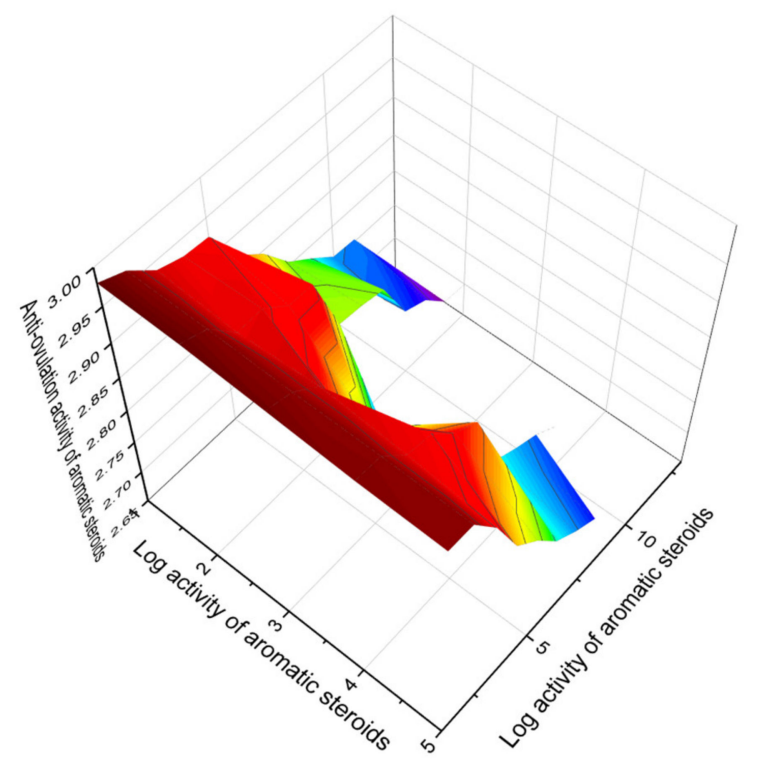

(a)

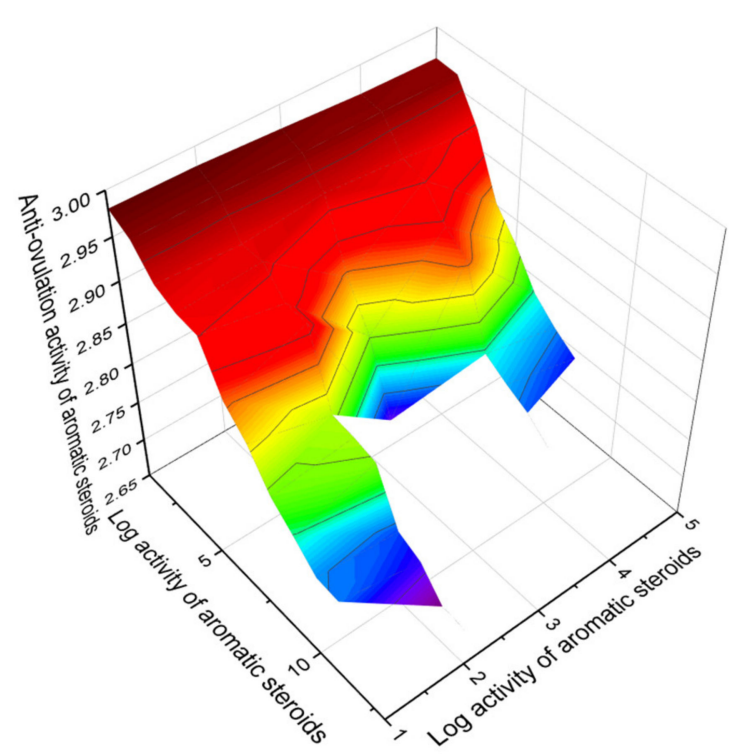

(b)

Figure 2. The 3D graph $(X(\mathbf{a})$ and $Y(\mathbf{b})$ views) shows the predicted and calculated antiovulation activity of aromatic steroids (compound numbers: 7, 9, 1, 8, and 10) showing the highest degree of confidence, more than $92.5 \%$. These steroids are derived from animals, including humans, as well as the extract of bark from the main wooden rod of ketapang Terminalia catappa, and can be used in clinical medicine as potential agents with strong ovulation inhibitors. The units of measurement of the $x-y$ digits (Cos-Sin or Sin-Sin) are the relative dimensions that the Origin Pro 2021 graphics program chooses independently, depending on the data obtained by the PASS program. On the 3D graphs, the Origin Pro software in red indicates the maximum biological activity of an individual steroid, and blue indicates the minimum activity. 


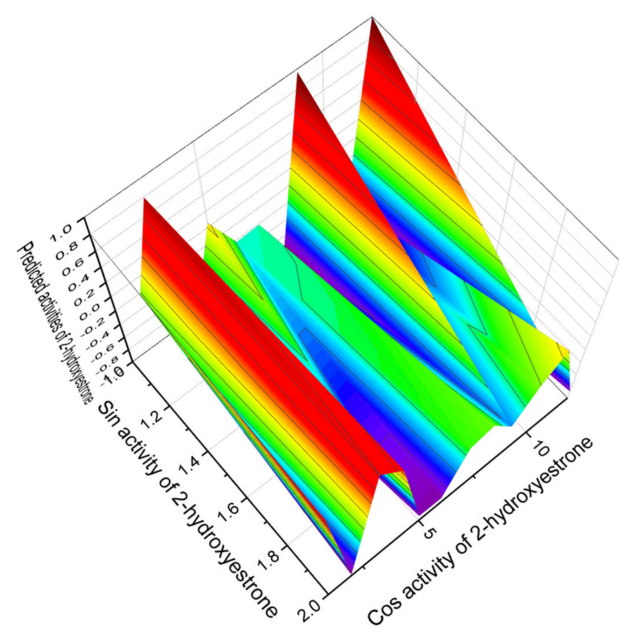

Figure 3. The $3 \mathrm{D}$ graph shows the predicted pharmacological activities of 2-hydroxyestrone (7). 2Hydroxyestrone (2-OHE1) or 2.3-estracatechol, also known as estra-1,3,5(10)-trien-2,3-diol-17-one, is an endogenous, naturally occurring catechol estrogen that was first isolated from human urine more than 60 years ago [106], apparently as a product of estrone and estradiol metabolism. According to the PASS data, 2-hydroxyestrone is the strongest ovulation inhibitor among aromatic steroids. In addition, it is a cardiovascular analeptic and can be used as a drug for the treatment and prevention of male reproductive dysfunction, menopausal disorders in women, as well as treatment of muscular dystrophy.

Among the second group of aromatic steroids that demonstrate strong antihypercholesterolemic activity, and a 3D graph of predicted and calculated antihypercholesterolemic activity is shown in Figure 4; the strongest steroid is estrone glucuronide (6), and a 3D graph of its predicted pharmacological activities is shown in Figure 5.

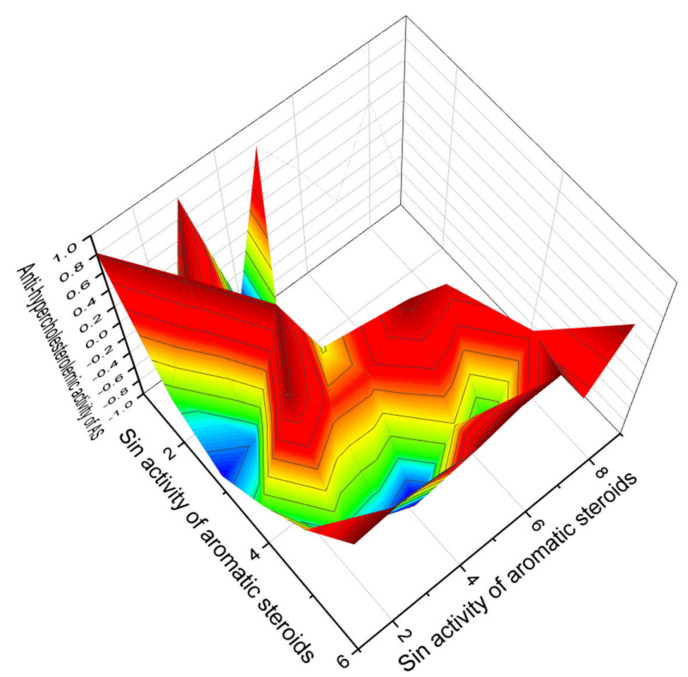

Figure 4. The 3D graph showing the predicted and calculated antihypercholesterolemic activity of aromatic steroids (compound numbers: 6, 13, 11, 14, 15, and 19) with the highest degree of confidence, more than $94.6 \%$. These steroids have been obtained from a variety of natural sources, including plant, fungal, and marine invertebrate extracts, and appear to be useful in clinical medicine as potential agents with potent antihypercholesterolemic activity. 


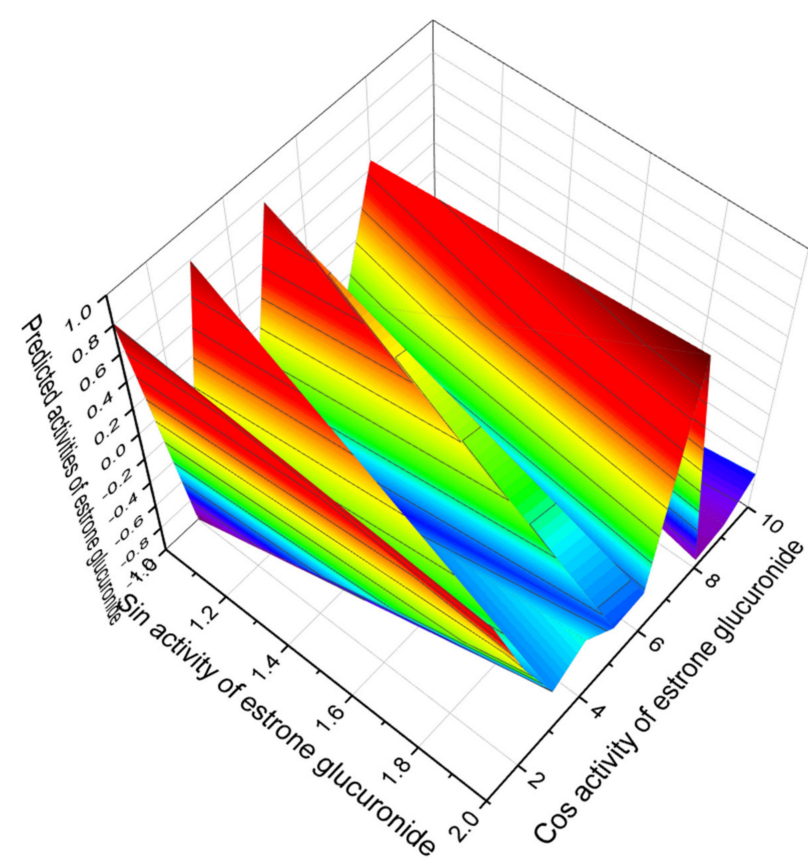

Figure 5. The 3D graph shows the predicted pharmacological activities of estriol 3-glucuronide (6). The water-soluble conjugate of estriol, also known as estriol 3- $\beta$-D-glucosiduronic acid, is a naturally occurring steroidal estrogen containing $\beta$-D-glucopyranuronic acid that was first discovered and isolated from the urine of women in the late 1930s [107-109]. According to the PASS data, estrone glucuronide, in addition to the main antihypercholesterolemic activity (97.3\%), is also a potent regulator of lipid metabolism with a reliability of $90.7 \%$ and can be used to treat acute neurological disorders $(92.2 \%)$.

\section{Natural, Semi-, and Synthetic Steroid Phosphate Esters}

Steroid phosphate esters are rare lipid molecules that can form the building blocks of biological membranes and have been found more recently in starfish extracts. So, for the first time, steroid phosphates were discovered more than a quarter of a century ago by Italian scientists from the University of Frederico II, in the city of Napoli. Unique steroids were isolated from the extract of the polar lipids of the starfish Tremaster novaecaledoniae, which was collected at a depth of $530 \mathrm{~m}$ of New Caledonia [110]. The isolated phosphated steroid glycosides were called tremasterols $A$ and $C$, and their structures were identified as $3 \beta$-O-sulphated, $6 \alpha$-O-phosphated, and $16 \beta$-O-acetylated groupings on a steroidal skeleton (21, 22, and 23).

Synthetic steroids, such as testosterone $17 \beta$-phosphate (24), cortisol 21-phosphate (25), and cholesterol $3 \beta$-phosphate (26), were chosen by us for comparison of biological activity with the activity of steroids isolated from marine invertebrates [111]. Testosterone $17 \beta$-phosphate (24) is an androgen and belongs to the class of anabolic steroids and is used for intramuscular injection, and it is a substrate for phosphatases in the phosphatase pool of the prostate [112]. Cortisol 21-phosphate (25) refers to the glucocorticoid class of hormones, and it functions to increase blood sugar levels through gluconeogenesis and to promote the metabolism of fats, proteins, and carbohydrates, and it is a substrate for alkaline phosphatase and is used for an enzyme immunoassay for human chorionic gonadotropin, human growth hormone, and $\alpha$-fetoprotein and estradiol [113]. Cholesterol $3 \beta$-phosphate (26) promotes normalization of blood pressure and plays an important role in atherogenesis $[114,115]$.

Two novel cholesterol-lowering agents called sodium ascorbic campestanol phosphate (27) and sodium ascorbic sitostanol phosphate (28) were synthesized, and their properties were studied [116]. Using Western blot analysis of P-GP expression, it was shown that changes in mdr-1 gene expression lead to correlating changes in P-GP protein expression. More recently, two steroid phosphate esters (29 and 30, structures see on Figure 6 and 
activities on Table 2) have been synthesized, acting as inhibitors of cholesterol biosynthesis. Methods of treating or preventing various diseases, conditions, and disorders by administering these steroids or compositions are also provided [117]. Estradiol phosphate (31) is ester of estrogen with phosphoric acid and acts as a prodrug of estradiol in the human body. In medical practice, both drugs can be used to treat prostate cancer [118].

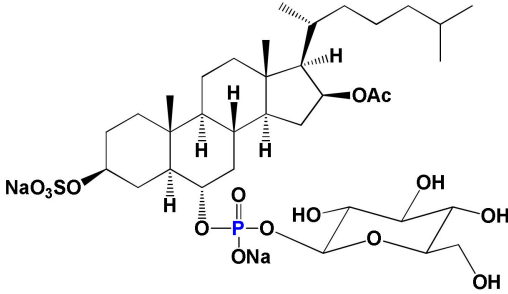

21 Tremasterol A

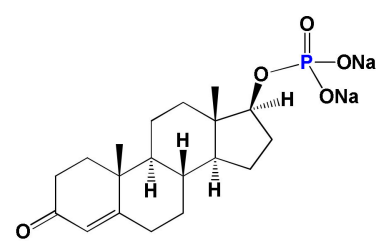

24 Testosterone $17 \beta$-phosphate

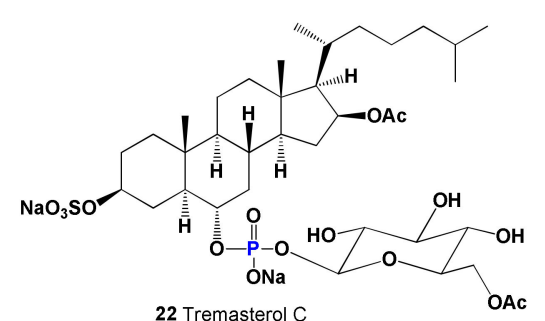

22 Tremasterol $C$
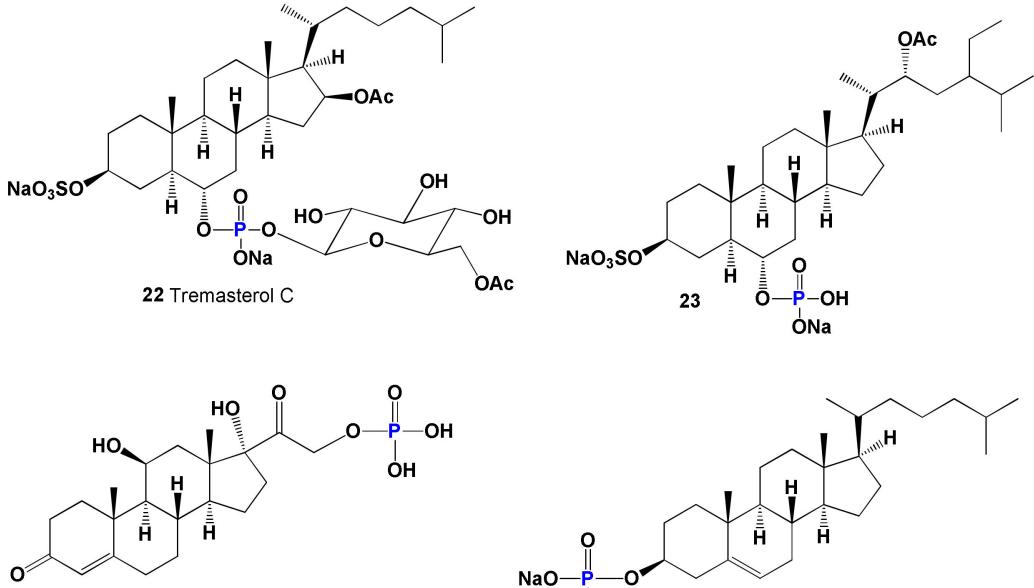

25 Hydrocortisone 21-phosphate

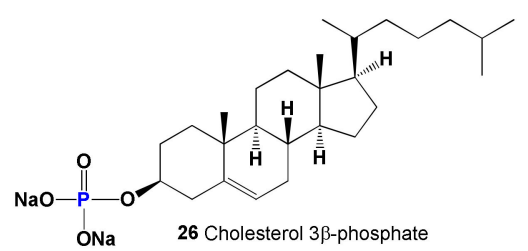

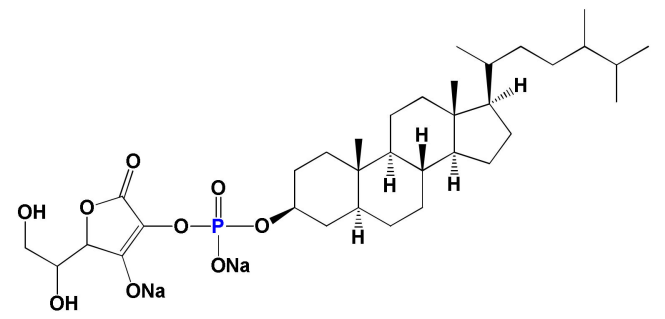

27 Di-Na ascorbyl campestanol phosphate
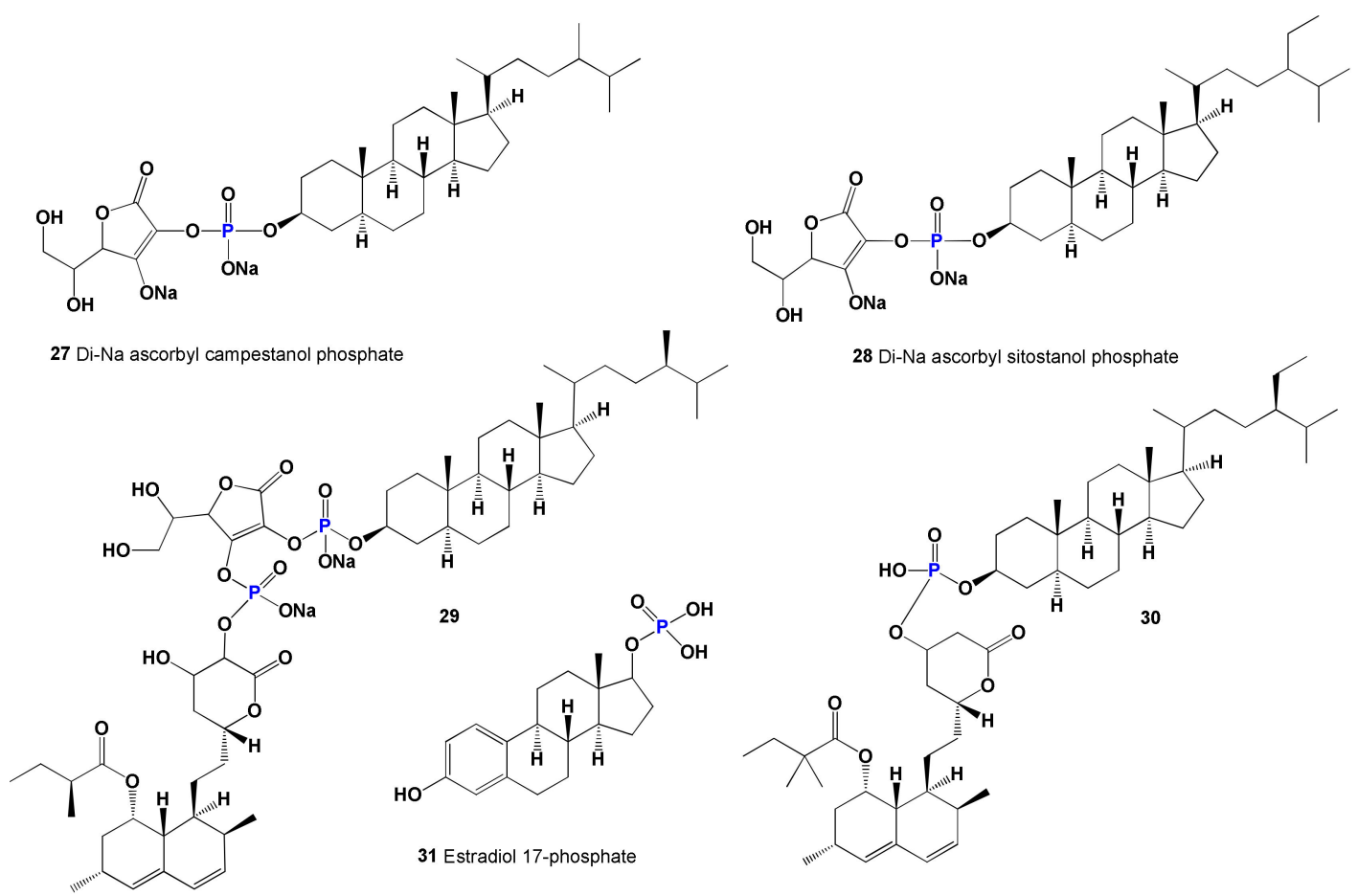

$\mathrm{OH}$

28 Di-Na ascorbyl sitostanol phosphate

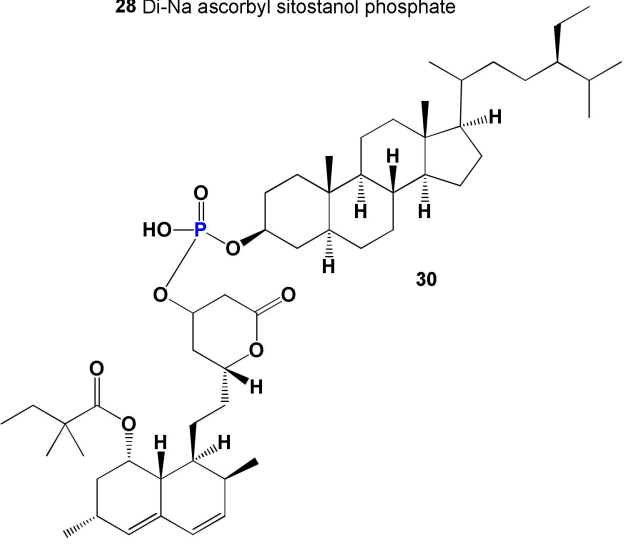

Figure 6. Bioactive natural, semi-synthetic, and synthetic steroid phosphate esters. 
Table 2. Predicted biological activities of steroid phosphate esters.

\begin{tabular}{|c|c|c|c|}
\hline No. & Lipid Metabolism Regulators, $(\mathrm{Pa})$ * & Reported Activity & Ref. \\
\hline 21 & $\begin{array}{c}\text { Wound healing agent }(0.975) \\
\text { Hepatoprotectant }(0.961) \\
\text { Analeptic }(0.952) \\
\text { Antihypercholesterolemic }(0.926) \\
\text { Cholesterol synthesis inhibitor }(0.799)\end{array}$ & Activity not studied & \\
\hline 22 & $\begin{array}{c}\text { Wound healing agent }(0.947) \\
\text { Analeptic }(0.941) \\
\text { Hepatoprotectant }(0.932) \\
\text { Anticarcinogenic }(0.915) \\
\text { Antihypercholesterolemic }(0.912) \\
\text { Cholesterol synthesis inhibitor }(0.778)\end{array}$ & Activity not studied & \\
\hline 23 & $\begin{array}{c}\text { Antihypercholesterolemic }(0.900) \\
\text { Hepatoprotectant }(0.853) \\
\text { Wound healing agent }(0.844) \\
\text { Antineoplastic }(0.816) \\
\text { Antiinflammatory }(0.782) \\
\text { Cholesterol synthesis inhibitor }(0.778) \\
\text { Atherosclerosis treatment }(0.675)\end{array}$ & Activity not studied & \\
\hline 24 & $\begin{array}{c}\text { Neuroprotector }(0.987) \\
\text { Anesthetic general }(0.959) \\
\text { Respiratory analeptic }(0.944) \\
\text { Antihypercholesterolemic }(0.909)\end{array}$ & Substrate for phosphatases & [112] \\
\hline 25 & $\begin{array}{c}\text { Anesthetic general }(0.991) \\
\text { Respiratory analeptic }(0.990) \\
\text { Neuroprotector }(0.976) \\
\text { Antiinflammatory }(0.906) \\
\text { Antihypercholesterolemic }(0.900)\end{array}$ & Increases blood sugar levels & [113] \\
\hline 26 & $\begin{array}{c}\text { Respiratory analeptic }(0.979) \\
\text { Anesthetic general }(0.973) \\
\text { Neuroprotector }(0.972) \\
\text { Antihypercholesterolemic }(0.971) \\
\text { Wound healing agent }(0.913) \\
\text { Antineoplastic }(0.826) \\
\text { Cholesterol synthesis inhibitor }(0.801)\end{array}$ & Stabilizes blood pressure & [114] \\
\hline 27 & $\begin{array}{c}\text { Respiratory analeptic }(0.995) \\
\text { Anesthetic general }(0.948) \\
\text { Antihypercholesterolemic }(0.945) \\
\text { Neuroprotector }(0.932) \\
\text { Hemostatic }(0.910) \\
\text { Wound healing agent }(0.897) \\
\text { Cholesterol synthesis inhibitor }(0.867) \\
\text { Acute neurologic disorders treatment }(0.827)\end{array}$ & Reduces cholesterol levels & [116] \\
\hline 28 & $\begin{array}{c}\text { Antihypercholesterolemic }(0.967) \\
\text { Wound healing agent }(0.921) \\
\text { Neuroprotector }(0.909) \\
\text { Cholesterol synthesis inhibitor }(0.872)\end{array}$ & Reduces cholesterol levels & [116] \\
\hline 29 & $\begin{array}{c}\text { Antihypercholesterolemic }(0.996) \\
\text { Cholesterol absorption inhibitor }(0.976) \\
\text { Cholesterol synthesis inhibitor }(0.952) \\
\text { Lipid metabolism regulator }(0.952) \\
\text { Lipoprotein disorders treatment }(0.893)\end{array}$ & $\begin{array}{l}\text { Cholesterol biosynthesis } \\
\text { inhibitor }\end{array}$ & [117] \\
\hline 30 & $\begin{array}{c}\text { Antihypercholesterolemic }(0.999) \\
\text { Antihyperlipoproteinemic }(0.986) \\
\text { Hypolipemic }(0.974) \\
\text { Cholesterol absorption inhibitor }(0.957) \\
\text { Lipid metabolism regulator }(0.954) \\
\text { Cholesterol synthesis inhibitor }(0.916) \\
\text { Lipoprotein disorders treatment }(0.782) \\
\text { Acute neurologic disorders treatment }(0.751) \\
\text { Atherosclerosis treatment }(0.729)\end{array}$ & $\begin{array}{l}\text { Cholesterol biosynthesis } \\
\text { inhibitor }\end{array}$ & [117] \\
\hline 31 & $\begin{array}{c}\text { Neuroprotector }(0.982) \\
\text { Anesthetic general }(0.931) \\
\text { Antihypercholesterolemic }(0.909) \\
\text { Acute neurologic disorders treatment }(0.831) \\
\text { Prostate disorders treatment }(0.640)\end{array}$ & $\begin{array}{l}\text { Remedy for the treatment } \\
\text { of prostate cancer }\end{array}$ & [118] \\
\hline
\end{tabular}

* Only activities with $\mathrm{Pa}>0.5$ are shown.

\section{Comparison of Biological Activities of Steroid Phosphate Esters}

According to PASS, antihypercholesterolemic activity is characteristic of all steroid phosphate esters presented in Table 2 with varying degrees of confidence. In addition, all steroids are inhibitors of cholesterol synthesis, except for steroid 31. However, some lipid steroidal molecules such as 21-23 can be agents for wound healing and hepato-protectors 
with a high degree of certainty, and steroids $\mathbf{2 3 - 2 8}$ and $\mathbf{3 1}$ also demonstrate the properties of a neuroprotective agent with a high degree of certainty from 90 to $98 \%$.

Steroid phosphate esters are of great practical interest in medicine, as they are wound healing agents. The confidence level of steroid 21 is $97.5 \%$. Figure 7 shows the 3D graph of biological activities with a dominant property as a wound healing agent.

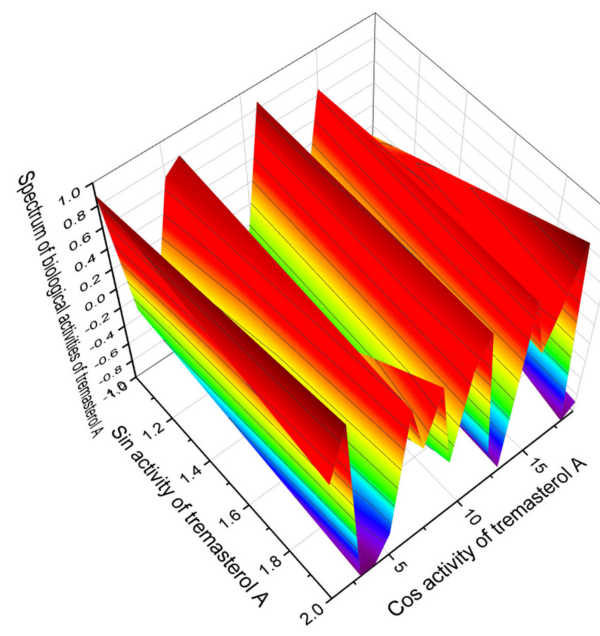

Figure 7. The 3D graph showing the predicted pharmacological activities of tremasterol A (21). Data from the PASS program show that phosphated steroid glycoside named tremasterol A exhibits 20 different biological activities, with dominant properties as a wound healing agent. Interestingly, tremasterol A is isolated from the starfish Trenzaster novaecaledoniae. This is a rare occasion when glycosides from starfish demonstrate such beneficial biological activities.

The sitostanol derivative (30) was synthesized by scientists from British Columbia (Canada) as a strong inhibitor of cholesterol synthesis, and as shown by the PASS data, this lipid molecule is in fact an excellent drug for the treatment of atherosclerosis. The wide range of biological activities of the sitostanol derivative (30) is shown in Figure 8.

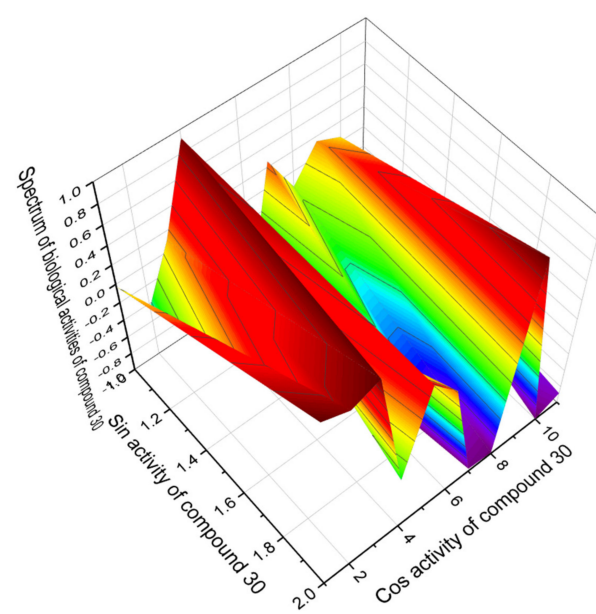

Figure 8. The 3D graph showing the predicted pharmacological activities of the sitostanol derivative (30). This drug has antihypercholesterolemic and antihyperlipoproteinemic properties that help lower cholesterol levels in the human body and reduce the risk of strokes and heart attacks. In addition, the drug is a strong cholesterol absorption inhibitor with a confidence level of $95.7 \%$ and a regulator of lipid metabolism with a confidence level of $95.4 \%$ and can be used to treat acute neurological disorders. 


\section{Highly Oxygenated Natural Steroids and Triterpenoids}

Highly oxygenated steroids are a large group of steroids and triterpenoids found in plant, fungal, and invertebrate extracts, and many of them exhibit a wide range of biological activities. This group of lipids includes secosteroids, epoxy steroids and peroxy steroids, and triterpenoids, which demonstrate a high degree of activity as potential regulators of lipid metabolism [119-123].

\subsection{Secosteroids Derived from Marine and Terrestrial Sources}

Secosteroids are a large group of natural steroidal hormones with a so-called 'broken' ring by oxidation of rings $\mathrm{A}, \mathrm{B}, \mathrm{C}$, or D. Typical representatives of secosteroids are fatsoluble vitamins of group D [124-127]. Secosteroids are found in plant and animal extracts, produced by fungi, and found in marine invertebrates and algae [121,128-130].

Two secosterols, $3 \beta$-hydroxy- $8 \alpha, 9 \alpha$-oxido-8,9-secoergosta-7,9(11),22-triene (32) and $3 \beta$-hydroxy- $8 \alpha, 9 \alpha$-oxido-8,9-secoergosta-7,22-dien-12-one (33), named tylopiol A and B, respectively, were isolated from the fresh fruit bodies of fungus Tylopilus plumbeoviolaceus [131]. The other two steroids, named gloeophyllin J (34) and I (35), have been isolated from the solid cultures of North American wood-rotting fungi Gloeophyllum abietinum. Both compounds showed cytotoxic activity against human cancer cell lines K562 and HCT116 [132]. The chemical structures of steroids are shown in Figure 9 and the biological activity is shown in Table 3.

7-Oxasteroid (36) was isolated and characterized from the culture of Aspergillus ochraceus EN-31. This endophytic fungus is found and isolated from the marine brown alga Sargassum kjellmanianum (Dalian coastline, China) [133]. Compound 36 has been previously reported from a Penicillium sp. [134], and it displayed cytotoxic activity against NCI-H460, SMMC-7721, and SW1990 cell lines with $\mathrm{IC}_{50}$ values of $12.1,16.9$, and $67.6 \mu \mathrm{M}$, respectively [133].

Secosteroid (37) has been determined in extracts of Australian soft coral Sinularia sp. [135,136], and other octocoral Sinularia leptoclados are sources of bioactive 9,11-secosteroids and steroid 3,11-dihydroxy-9,11-secogorgost-5-en-9-one (38), which showed the highest peroxisome proliferator-activated receptor (PPAR) activity with an $\mathrm{IC}_{50}$ value of $8.3 \mu \mathrm{M}$ for inhibiting human breast adenocarcinoma cell (MCF-7) growth. In addition, this steroid modulated the expression of various PPAR-regulated downstream biomarkers, including cyclin D1, cyclin-dependent kinase, B-cell lymphoma 2 (Bcl-2), p38, and extracellular-signal-regulated kinase $[137,138]$. 


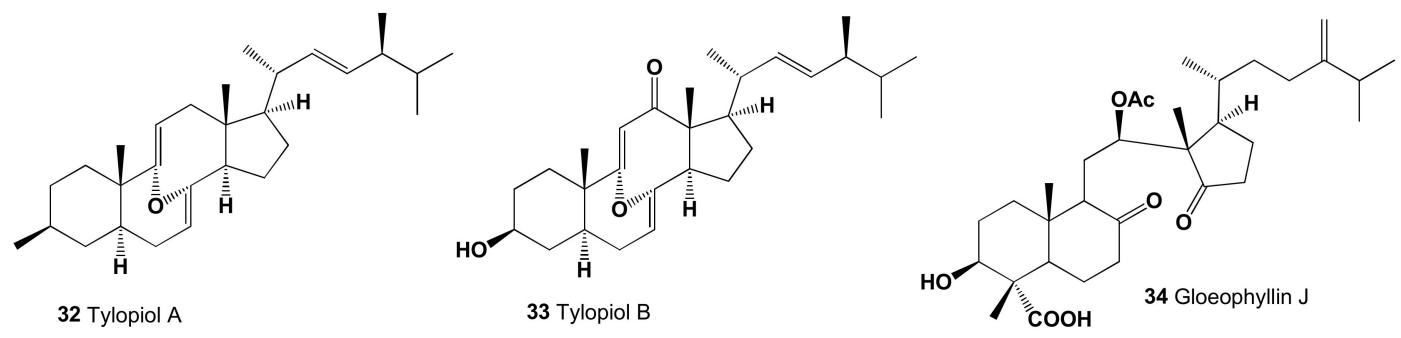

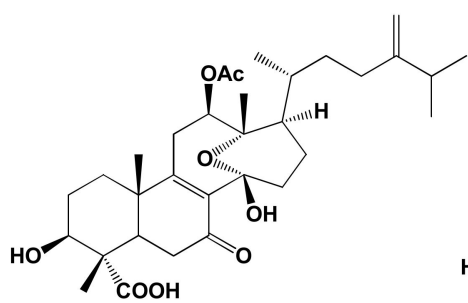<smiles>C=C(CC[C@H](C)[C@H]1CC[C@H]2C3=C(CC[C@]21C)[C@@]1(C)CC[C@@H](O)C[C@H]1CO3)C(C)C(C)C</smiles>

35 Gloeophyllin I<smiles>C=C(C(C)C)C1C[C@H]1[C@H](C)[C@@H]1CC[C@H](C2CC=C3C[C@@H](O)CC[C@]3(C)C2=O)[C@]1(C)CCO</smiles><smiles>C=C1CC[C@@H](O)C/C1=C/C=C1\CCC[C@@]2(C)[C@H]([C@H](C)/C=C/[C@H](C)C(C)C)CC[C@@H]12</smiles><smiles>CC[C@]1(CCO)[C@@H](C2CC3OC34C[C@H](O)CC[C@]2(C)C4=O)CC[C@@H]1[C@@H](C)CCCC(C)C</smiles>

Figure 9. Secosteroids showing activity as lipid metabolism regulators.

Vitamin D2, known as ergocalciferol or 9,10-seco-(5Z,7E)-5,7,10(19),22-ergostatetraene$3 \beta-o l(39)$, is the main one that is used in human nutrition [139]. All forms of vitamin D were found in mushrooms (brown Italian cremini, chanterelle, enoki, maitake, morel, shiitake, oyster, portobello, and white button mushrooms) and yeast [140-145]. Secosteroid, 3,11-dihydroxy-5,6-epoxy-9,11-secocholestan-9-one (40), was found and identified from extracts of the Taiwanese soft coral Cespitularia taeniata [146].

Table 3. Predicted biological activities of secosteroids.

\begin{tabular}{|c|c|c|c|}
\hline No. & Discovered Activity, (Pa) * & Reported Activity & Ref. \\
\hline 32 & $\begin{array}{c}\text { Antihypercholesterolemic }(0.912) \\
\text { Hypolipemic }(0.802) \\
\text { Atherosclerosis treatment }(0.643) \\
\text { Antiparkinsonian, rigidity relieving } \\
(0.562)\end{array}$ & Activity not studied & \\
\hline 33 & $\begin{array}{l}\text { Antihypercholesterolemic }(0.905) \\
\text { Hypolipemic }(0.753) \\
\text { Atherosclerosis treatment }(0.559)\end{array}$ & Activity not studied & \\
\hline 34 & $\begin{array}{c}\text { Antihypercholesterolemic }(0.908) \\
\text { Antineoplastic }(0.785) \\
\text { Hypolipemic }(0.764) \\
\text { Apoptosis agonist }(0.747) \\
\text { Cholesterol synthesis inhibitor }(0.744)\end{array}$ & Anticancer & [131] \\
\hline
\end{tabular}


Table 3. Cont.

\begin{tabular}{|c|c|c|c|}
\hline No. & Discovered Activity, (Pa) * & Reported Activity & Ref. \\
\hline 35 & $\begin{array}{c}\text { Antihypercholesterolemic }(0.916) \\
\text { Antineoplastic }(0.833) \\
\text { Hypolipemic }(0.827) \\
\text { Apoptosis agonist }(0.771) \\
\text { Cholesterol synthesis inhibitor }(0.685) \\
\text { Atherosclerosis treatment }(0.633)\end{array}$ & Anticancer & [131] \\
\hline 36 & $\begin{array}{c}\text { Antihypercholesterolemic }(0.904) \\
\text { Hypolipemic }(0.767) \\
\text { Antineoplastic }(0.743) \\
\text { Apoptosis agonist }(0.676) \\
\text { Proliferative diseases treatment }(0.625) \\
\text { Atherosclerosis treatment }(0.539)\end{array}$ & Anticancer & [133] \\
\hline 37 & $\begin{array}{l}\text { Antihypercholesterolemic }(0.915) \\
\text { Lipid metabolism regulator }(0.768)\end{array}$ & Activity not studied & \\
\hline 38 & $\begin{array}{l}\text { Antihypercholesterolemic (0.909) } \\
\text { Hypolipemic }(0.786)\end{array}$ & Anticancer & [147] \\
\hline 39 & $\begin{array}{c}\text { Antiparkinsonian, rigidity relieving } \\
(0.960) \\
\text { Hyperparathyroidism treatment } \\
(0.892) \\
\text { Antihypercholesterolemic }(0.845) \\
\text { Hypolipemic }(0.790) \\
\text { Atherosclerosis treatment }(0.628)\end{array}$ & $\begin{array}{c}\text { Calcium and } \\
\text { phosphates } \\
\text { metabolism regulator }\end{array}$ & [148] \\
\hline 40 & $\begin{array}{c}\text { Chemopreventive }(0.989) \\
\text { Hepatoprotectant }(0.986) \\
\text { Respiratory analeptic }(0.978) \\
\text { Antihypercholesterolemic }(0.977) \\
\text { Proliferative diseases treatment }(0.969) \\
\text { Antimycobacterial }(0.939) \\
\text { Neuroprotector }(0.895) \\
\text { Antineoplastic }(0.874) \\
\text { Antiprotozoal (Leishmania) }(0.772) \\
\text { Atherosclerosis treatment }(0.601) \\
\text { Neurodegenerative diseases treatment } \\
\text { (0.590) } \\
\text { Alzheimer's disease treatment }(0.570)\end{array}$ & $\begin{array}{l}\text { Activity not studied } \\
\text { previously }\end{array}$ & \\
\hline
\end{tabular}

* Only activities with Pa $>0.5$ are shown.

\section{Comparison of Biological Activities of Secosteroids}

Among the secosteroids shown in Figure 9, which show activity as regulators of lipid metabolism, the most interesting is lipid molecule number 40, which has aAntihypercholesterolemic activity with a confidence level of 97.7 percent. Figure 10 shows the 3D graph of the predicted pharmacological activities of this steroid. Ergocalciferol (39) or vitamin D2 is also of great interest, as PASS showed strong antiparkinson activity with a confidence level of $96.0 \%$. The full spectrum of the predicted pharmacological activities of ergocalciferol is shown in the 3D graph in Figure 11. 


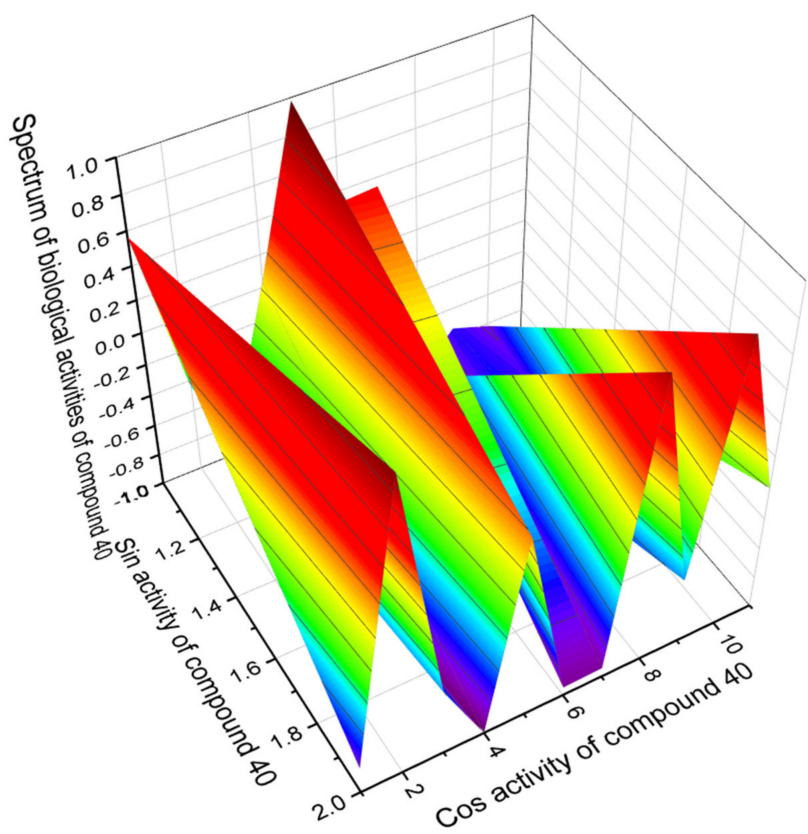

Figure 10. The 3D graph shows the predicted pharmacological activities of compound (40). This secosteroid is characterized by antihypercholesterolemic properties. In addition, it exhibits hepatoprotective properties, and it is an inhibitor of cell proliferation, which de facto can prevent several pathological diseases such as atherosclerosis, rheumatoid arthritis, psoriasis, idiopathic pulmonary fibrosis, scleroderma, and liver cirrhosis.

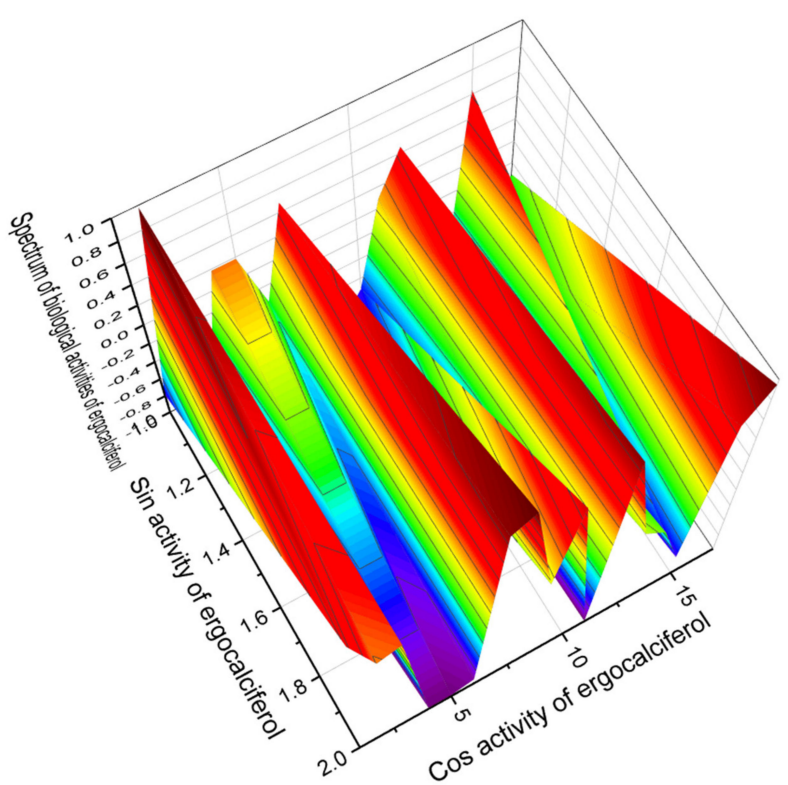

Figure 11. The 3D graph showing the predicted pharmacological activities of ergocalciferol (39). A secosterol hormone called ergocalciferol was first isolated as a radiation product of 7-dehydrocholesterol and described in 1936 by Windaus and co-workers [149]. Ergocalciferol is an important drug and is recommended by the World Health Organization. In addition, it has anticancer, anti-inflammatory, and antieczema properties, and can also be recommended as an antihypercholesterolemic agent and an agent against Parkinson's disease. Certain foods, such as breakfast cereals and margarine, contain ergocalciferol in some countries, and it is found in the lichen Cladina arbuscula and alfalfa (Medicago sativa) [150-154]. 


\subsection{Natural Epoxy Steroids Derived from Marine Sources}

$\alpha, \alpha$-epoxy- and/or $\beta, \beta$-steroids are found in lipid extracts of marine invertebrates, including sponges, soft corals, starfish, and nudibranchs (Mollusca) [123,155-159]. Two cy-

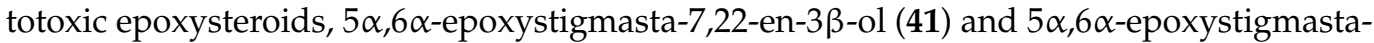
7-en-3 $\beta$-ol (42) were isolated from the ethanolic extract of the marine sponge Ircinia aruensis [160]. The chemical structures of steroids are shown in Figure 12 and the biological activity is shown in Table 4. Topsentisterol B4 (43), epoxy steroid with the $\beta$ - and $\alpha$ hydroxyl groups at position 3 and 7, respectively, were present in the extract of the far eastern sponge of Topsentia sp. [161]. (24E)- $5 \alpha, 6 \alpha$-epoxystigmasta-7,24(28)-dien-3 $\beta$-ol (44) was isolated from the South China Sea sponge Phyllospongia foliascens without studying the biological activity [162]. Triterpene glycoside, eryloside U (45) with be the 7,8-epoxide group was isolated from the sponge Erylus goffrilleri collected near Arresife-Seko Reef (Cuba) [163].

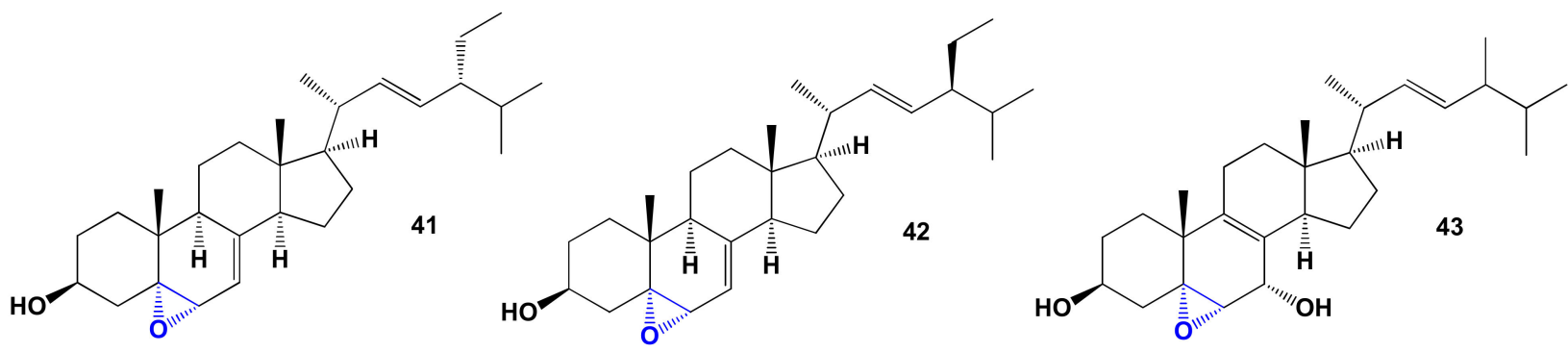

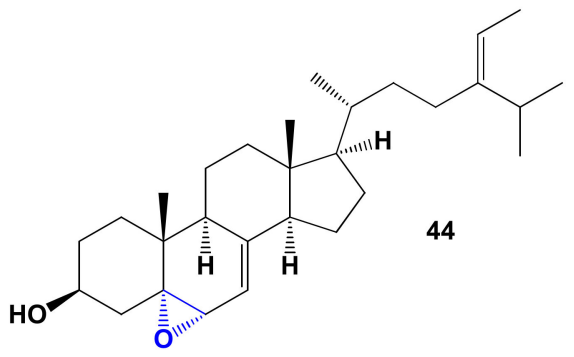

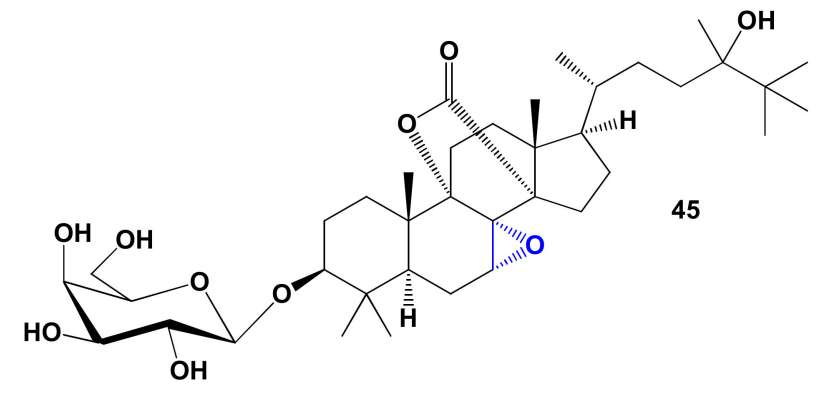

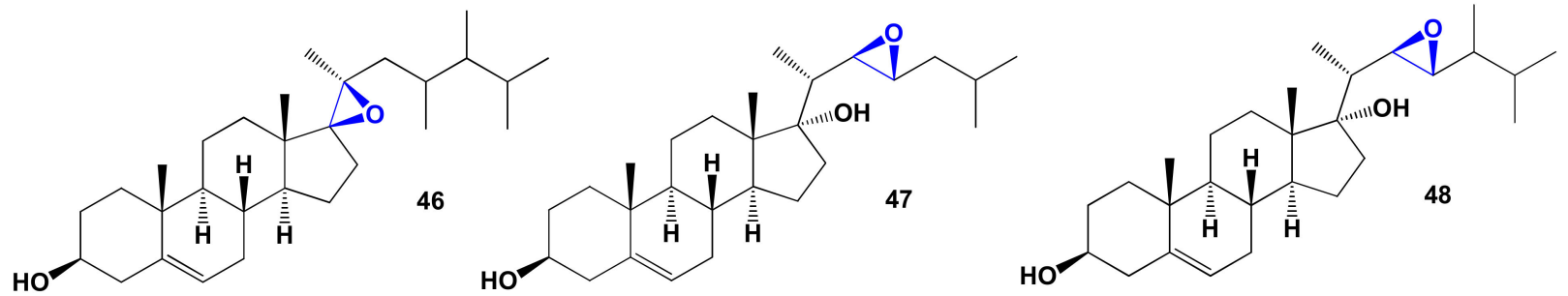

Figure 12. Bioactive $\alpha, \beta$-epoxy steroids derived from marine sources.

Unusual $17 \beta, 20 \beta$-epoxy-23,24-dimethylcholest-5-ene-3 $\beta, 22$-diol (46) was found in the Indian Ocean soft coral Sarcophyton crassocaule [164]. 
Table 4. Predicted biological activities of $\alpha, \beta$-epoxy steroids.

\begin{tabular}{|c|c|c|c|}
\hline No. & Discovered Activity, $(\mathrm{Pa}) *$ & Reported Activity & Ref. \\
\hline 41 & $\begin{array}{c}\text { Apoptosis agonist }(0.950) \\
\text { Antihypercholesterolemic }(0.931) \\
\text { Antineoplastic }(0.886) \\
\text { Antieczematic }(0.842) \\
\text { Atherosclerosis treatment }(0.712)\end{array}$ & Cytotoxic & [160] \\
\hline 42 & $\begin{array}{c}\text { Apoptosis agonist }(0.950) \\
\text { Antihypercholesterolemic }(0.931) \\
\text { Antineoplastic }(0.886) \\
\text { Antieczematic }(0.842) \\
\text { Atherosclerosis treatment }(0.712)\end{array}$ & Cytotoxic & [160] \\
\hline 43 & $\begin{array}{l}\text { Apoptosis agonist }(0.954) \\
\text { Antineoplastic }(0.914) \\
\text { Antihypercholesterolemic }(0.906) \\
\text { Atherosclerosis treatment }(0.741)\end{array}$ & Activity not studied & \\
\hline 44 & $\begin{array}{c}\text { Antihypercholesterolemic }(0.934) \\
\text { Apoptosis agonist }(0.929) \\
\text { Hypolipemic }(0.864) \\
\text { Antineoplastic }(0.861)\end{array}$ & Activity not studied & \\
\hline 45 & $\begin{array}{c}\text { Hepatoprotectant }(0.994) \\
\text { Respiratory analeptic }(0.990) \\
\text { Antihypercholesterolemic }(0.897)\end{array}$ & Activity not studied & \\
\hline 46 & $\begin{array}{l}\text { Antihypercholesterolemic }(0.900) \\
\text { Neuroprotector }(0.749) \\
\text { Cholesterol synthesis inhibitor }(0.636)\end{array}$ & Activity not studied & \\
\hline 47 & $\begin{array}{l}\text { Antihypercholesterolemic }(0.901) \\
\text { Lipid metabolism regulator }(0.833) \\
\text { Prostate disorders treatment }(0.714)\end{array}$ & Anticancer & [165] \\
\hline 48 & $\begin{array}{l}\text { Antihypercholesterolemic }(0.924) \\
\text { Lipid metabolism regulator }(0.820) \\
\text { Neuroprotector }(0.728)\end{array}$ & Anticancer & [165] \\
\hline
\end{tabular}

Two diol 22,23-epoxy steroids have been isolated from the marine sponge Axinella cf. bidderi, $17 \alpha$-hydroxy-22 $\beta, 23 \beta$-epoxycholest-5-en- $3 \beta$-ol (47) and $17 \alpha$-hydroxy- $22 \beta, 23 \beta$ epoxy-24-methylcholest-5-en-3 $\beta$-ol (48). Isolated steroids showed activity against prostate, ovary, pancreas, colon, and lung cell lines in vitro [165].

Comparison of Biological Activities of $\alpha, \beta$-Epoxy Steroids Derived from Marine Sources

Comparing the data from the PASS obtained for the $\alpha, \beta$-epoxy steroids presented in Table 4, it can be concluded that there are no outstanding steroids with lipid metabolism regulator properties; then, we present in Figure 13 a comparative 3D graph for this subgroup of steroids. 


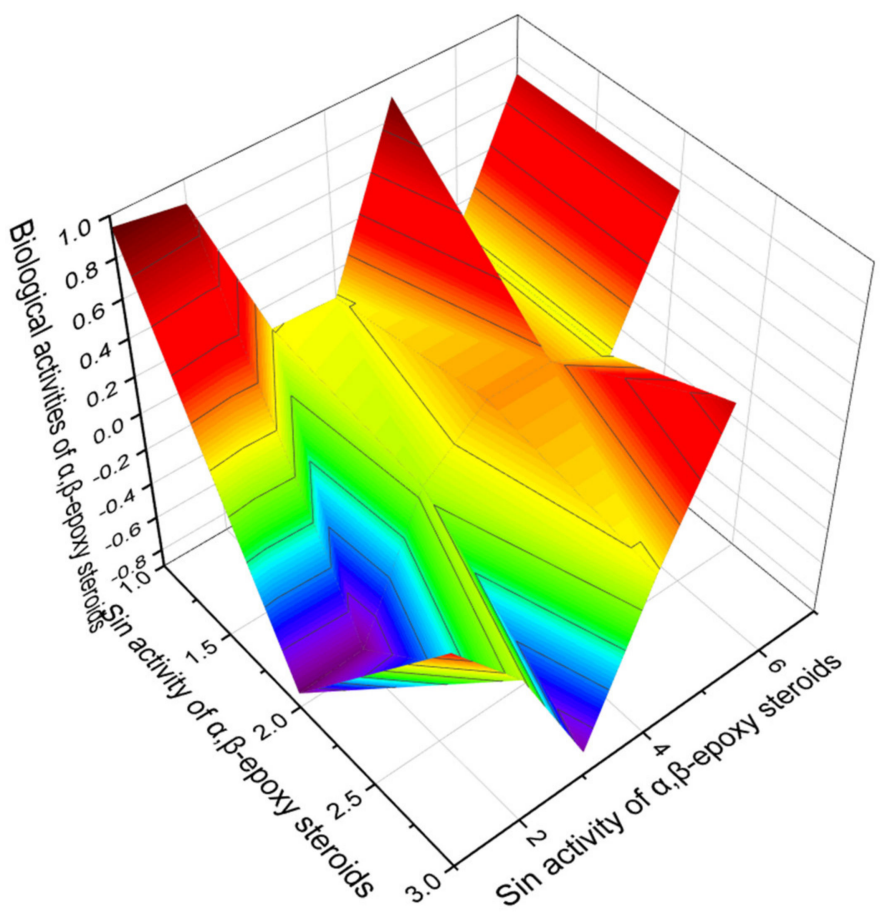

Figure 13. The 3D graph shows the predicted and calculated biological activity of $\alpha, \beta$-epoxy steroids (compound numbers: 42,44 , and 48 ) showing the highest degree of confidence, more than $92.4 \%$.

For a comparative graphic characterization of $\alpha, \beta$-epoxy steroids, we selected steroids numbered 42,44 , and 48 . All these lipids are characterized by the property of regulators of lipid metabolism with dominant antihypercholesterolemic activity. According to PASS data, steroids $\mathbf{4 2}$ and $\mathbf{4 4}$ also show a high level of anticancer activity, while steroid $\mathbf{4 8}$ is additionally characterized by neuroprotective properties.

\subsection{Peroxy-Type Steroids Derived from Natural Sources}

Natural and/or synthetic compounds containing a peroxy group (R-O-O-R) are called peroxides [166-172]. Natural peroxides represent a rather large group of compounds that many microorganisms produce, and they have also been found in plants, mushrooms, animals, and marine invertebrates [166-168]. Peroxy steroids are a small group of natural lipids, mainly found in leaves, roots, and bark of plants, and are produced by fungal endophytes and are found in mushrooms $[166,167,173]$.

\subsubsection{Steroid Endoperoxides}

Astropecten polyacanthus starfish extract has significant cytotoxic effects and contains an unusual peroxy steroid called astropectenol B (49) was isolated from a methanol extract of this starfish [174].

Cytotoxic steroid, (3,5,8,24R,25R)-epidioxy-24,26-cyclocholesta-6,9(11)-dien-3-ol (50) was identified from marine sponge Tethya sp. [175]. (3,5,8,24R)-Epidioxy-24-methylcholest6-en-3-ol (51) was detected in $\mathrm{MeOH}$ extract of the marine sponge Luffariella cf. variabilis [176], and 22,23-dihydro-5,8-epidioxystigmast-6-en-3-ol (52) was found in the marine sponges Luffariella cf. variabilis and Tethya sp. and sea squirt Dendrodoa grossularia [175-178].

Fuscoporianol D (53) was found in field-grown mycelia of fungus Inonotus obliquus (family Hymenochaetaceae) [179]. Ergosterol peroxide 3-O- $\beta$-D-glucopyranoside (54) produced by fungus Tremella fuciformis [180] and same compound was detected in the fruiting bodies of the Chinese toxic woodland mushroom Naematoloma fasciculare [181]. Endoperoxy steroid $\mathbf{5 5}$ was found in popular mushroom in Japan, Buna shimeji and in oyster fungus Pleurotus ostreatus [182]. Two endoperoxy glycosides (55 and 56) were found in ethanol extracts of the fungus Lactarius volemus, which demonstrated anticancer 
activity $[183,184]$. The chemical structures of steroids are shown in Figure 14, and the biological activity is shown in Table 5 .

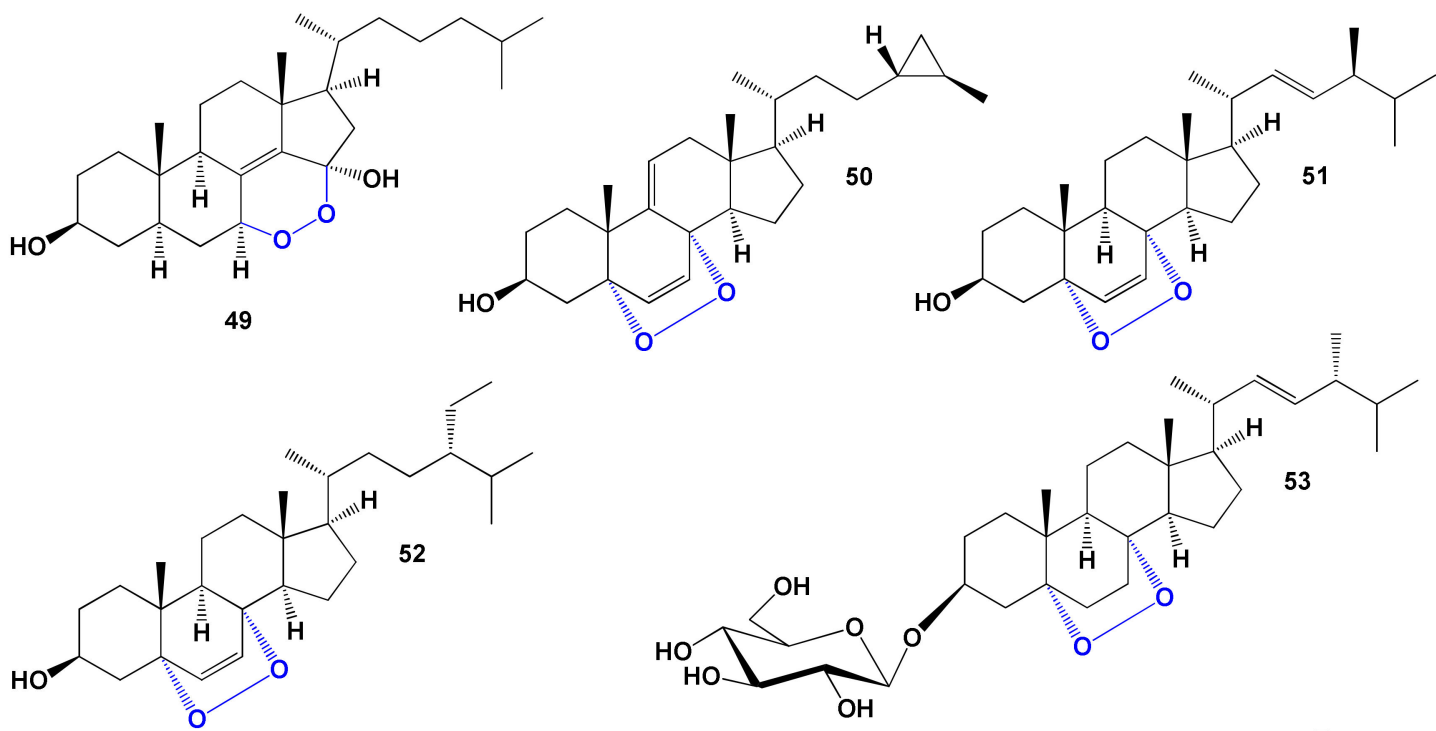

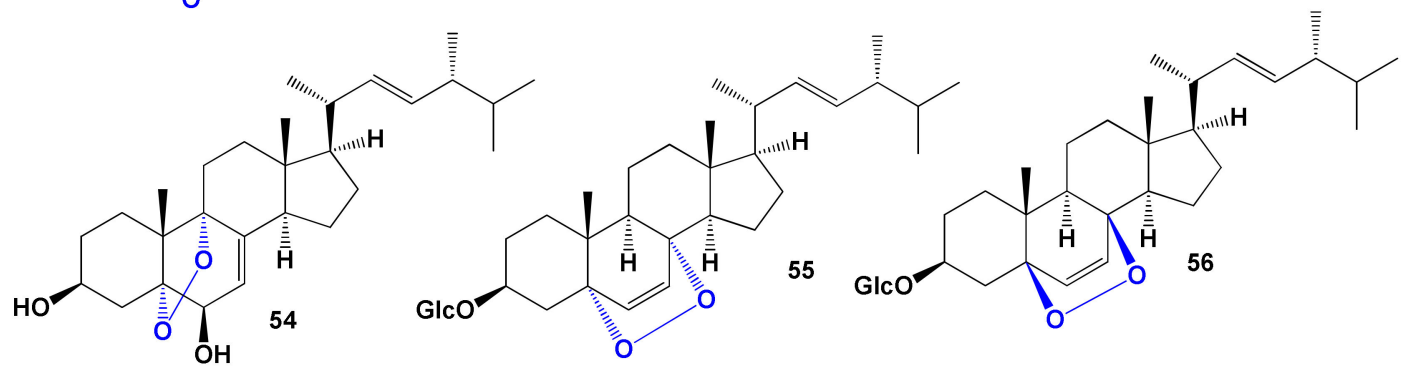

Figure 14. Bioactive steroid endoperoxides derived from marine sources and fungi.

Table 5. Biological activities of endoperoxy steroids.

\begin{tabular}{|c|c|c|c|}
\hline No. & Lipid Metabolism Regulators, $(\mathrm{Pa})$ * & Reported Activity & Ref. \\
\hline 49 & $\begin{array}{l}\text { Antihypercholesterolemic (0.914) } \\
\text { Hypolipemic }(0.635)\end{array}$ & Activity not studied & \\
\hline 50 & $\begin{array}{l}\text { Atherosclerosis treatment }(0.911) \\
\text { Hypolipemic }(0.836) \\
\text { Lipoprotein disorders treatment }(0.826) \\
\text { Antihypercholesterolemic }(0.802)\end{array}$ & Activity not studied & \\
\hline 51 & $\begin{array}{l}\text { Atherosclerosis treatment }(0.907) \\
\text { Antihypercholesterolemic }(0.788)\end{array}$ & Activity not studied & \\
\hline 52 & $\begin{array}{l}\text { Atherosclerosis treatment }(0.919) \\
\text { Hypolipemic }(0.822) \\
\text { Lipoprotein disorders treatment }(0.814)\end{array}$ & Activity not studied & \\
\hline 53 & $\begin{array}{l}\text { Antihypercholesterolemic }(0.926) \\
\text { Hypolipemic }(0.800) \\
\text { Atherosclerosis treatment }(0.709)\end{array}$ & Activity not studied & \\
\hline 54 & $\begin{array}{c}\text { Antihypercholesterolemic }(0.900) \\
\text { Hypolipemic }(0.827) \\
\text { Atherosclerosis treatment }(0.659) \\
\text { Hyperparathyroidism treatment }(0.502)\end{array}$ & Activity not studied & \\
\hline 55 & $\begin{array}{l}\text { Antihypercholesterolemic }(0.917) \\
\text { Hypolipemic }(0.786)\end{array}$ & Anticancer & [183] \\
\hline 56 & $\begin{array}{l}\text { Antihypercholesterolemic }(0.917) \\
\text { Atherosclerosis treatment }(0.858) \\
\text { Hypolipemic }(0.786)\end{array}$ & Anticancer & [183] \\
\hline
\end{tabular}

* Only activities with $\mathrm{Pa}>0.5$ are shown. 


\subsubsection{Steroid and Triterpenoid Hydroperoxides}

A flowering herbaceous perennial plant from the family Araceae, Arum italicum, also known as Italian arum and Italian lords-and-ladies, contains a suite of hydroperoxysterols, including two (57 and 58) that are interesting for lipid metabolism [185]. Two steroids (59 and 60), which showed a cytotoxic effect against several human cancer cell lines, have been isolated from the bark of the chinaberry tree, Melia azedarach [186]. The chemical structures of steroids are shown in Figure 15, and the biological activity is shown in Table 6.

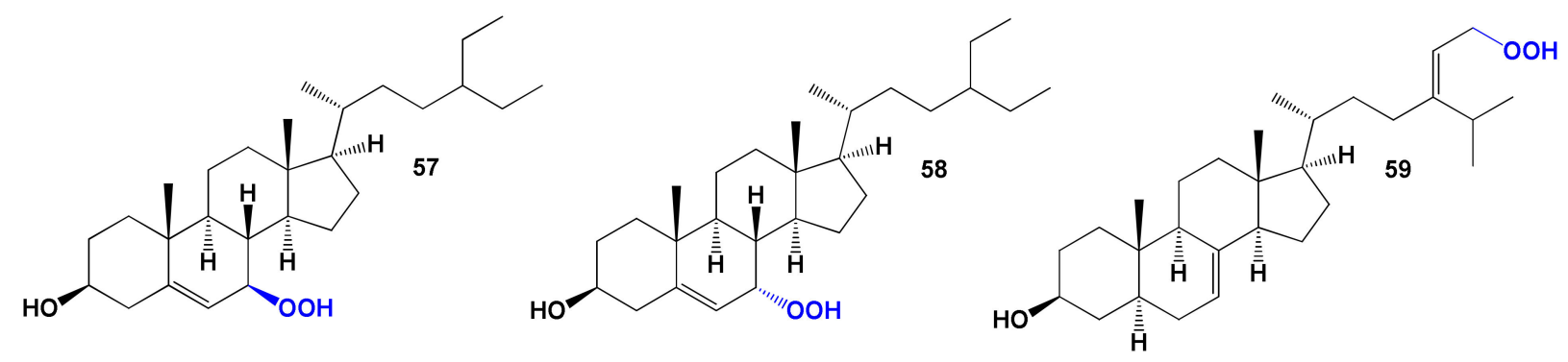<smiles>CCC(O)(CC[C@H](C)[C@H]1CC[C@H]2C3CC[C@@H]4C[C@@H](O)CC[C@]4(C)[C@@H]3CC[C@]2(C)[C@H]1C)C(C)C</smiles>

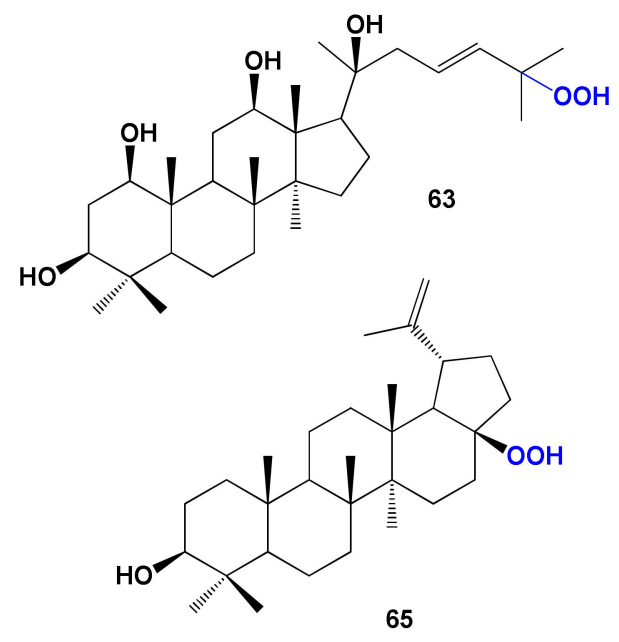<smiles>CC(C)(O)/C=C/CC(C)(O)C1CC[C@]2(C)[C@H]1CC[C@@H]1[C@]2(C)CCC2C(C)(C)[C@@H](O)CC[C@@]21C</smiles>

Figure 15. Bioactive steroid hydroperoxides derived from plants.

Ponce and co-workers obtained ergosterol 7-hydroperoxide (61) by the photo-oxidation of ergosterol with singlet oxygen in vivo and in vitro [187]. In addition, the yeast Saccharomyces cerevisiae with the singlet oxygen leads to rapid oxidation of ergosterol to ergosterol 7-hydroperoxide (61) [188].

A tree called Sakae Naa (Combretum quadrangulare) in Vietnam, Cambodia, Laos, Myanmar, and Thailand contained a cycloartane-type triterpene quadrangularic acid $\mathrm{F}$ (62), and the aqueous and $\mathrm{EtOH}$ extracts show antibacterial, anti-HIV, hepatoprotective, and cytotoxic activities [189-191].

The plant Proboscidea louisiana produced dammarane triterpenes known as probosciderol I (63) [192], and the stem bark of Rhus javanica contained isofouquierone peroxide (64) [193]. 
The leaves of Melaleuca ericifolia contained antiproliferative norlupane triterpene (65) [194], and the aerial roots of Ficus microcarpa afforded similar norlupane triterpene (66) [195].

Table 6. Predicted biological activities of hydroperoxy steroids.

\begin{tabular}{|c|c|c|c|}
\hline No. & Discovered Activity, (Pa) * & Reported Activity & Ref. \\
\hline 57 & $\begin{array}{c}\text { Antihypercholesterolemic }(0.905) \\
\text { Cholesterol synthesis inhibitor }(0.799)\end{array}$ & Activity not studied & \\
\hline 58 & $\begin{array}{c}\text { Antihypercholesterolemic }(0.905) \\
\text { Hypolipemic }(0.802) \\
\text { Cholesterol synthesis inhibitor }(0.621) \\
\text { Atherosclerosis treatment }(0.542)\end{array}$ & Activity not studied & \\
\hline 59 & $\begin{array}{c}\text { Antihypercholesterolemic }(0.933) \\
\text { Hypolipemic }(0.877) \\
\text { Cholesterol synthesis inhibitor }(0.644) \\
\text { Atherosclerosis treatment }(0.675) \\
\text { Prostate disorders treatment }(0.645)\end{array}$ & Cytotoxic & [186] \\
\hline 60 & $\begin{array}{c}\text { Antihypercholesterolemic }(0.933) \\
\text { Hypolipemic }(0.877) \\
\text { Antineoplastic }(0.835) \\
\text { Cholesterol synthesis inhibitor }(0.650) \\
\text { Atherosclerosis treatment }(0.554)\end{array}$ & Cytotoxic & [186] \\
\hline 61 & $\begin{array}{c}\text { Antihypercholesterolemic }(0.922) \\
\text { Hypolipemic }(0.868) \\
\text { Atherosclerosis treatment }(0.678) \\
\text { Antiparkinsonian, rigidity relieving } \\
(0.516)\end{array}$ & Activity not studied & \\
\hline 62 & $\begin{array}{c}\text { Antihypercholesterolemic }(0.913) \\
\text { Antineoplastic }(0.802) \\
\text { Hypolipemic }(0.795)\end{array}$ & $\begin{array}{c}\text { Hepatoprotective } \\
\text { Cytotoxic }\end{array}$ & [191] \\
\hline 63 & $\begin{array}{l}\text { Antihypercholesterolemic }(0.933) \\
\text { Hypolipemic }(0.877) \\
\text { Cholesterol synthesis inhibitor }(0.644)\end{array}$ & Activity not studied & \\
\hline 64 & $\begin{array}{c}\text { Antihypercholesterolemic }(0.923) \\
\text { Hypolipemic }(0.774) \\
\text { Cholesterol synthesis inhibitor }(0.604) \\
\text { Biliary tract disorders treatment } \\
(0.577)\end{array}$ & Activity not studied & \\
\hline 65 & $\begin{array}{c}\text { Antihypercholesterolemic }(0.918) \\
\text { Hypolipemic }(0.779) \\
\text { Biliary tract disorders treatment } \\
(0.655)\end{array}$ & Antiproliferative & [194] \\
\hline 66 & $\begin{array}{l}\text { Antihypercholesterolemic }(0.930) \\
\text { Hypolipemic }(0.767) \\
\text { Biliary tract disorders treatment }(0.717) \\
\text { Atherosclerosis treatment }(0.590)\end{array}$ & Activity not studied & \\
\hline
\end{tabular}

\subsubsection{Comparison of Biological Activities of Peroxy Steroids Derived from Natural Sources}

According to published data, most natural peroxides isolated from both plants and marine invertebrates show predominantly antiprotozoal activity. Such compounds include diterpenoids, triterpenoids, and steroids [166-168,171,173,196-199].

Analysis of PASS data on peroxy steroids and triterpenoids such as endoperoxides and hydroperoxides showed that most of these lipids have a high confidence level of more than 90 percent, but nevertheless, only three of all peroxy steroids deserve attention; these 
are steroids numbered 59, 63, and 66, which have a confidence level of over 93 percent. Figure 16 presents the 3D graph showing the predicted and calculated biological activity of steroid hydroperoxides.

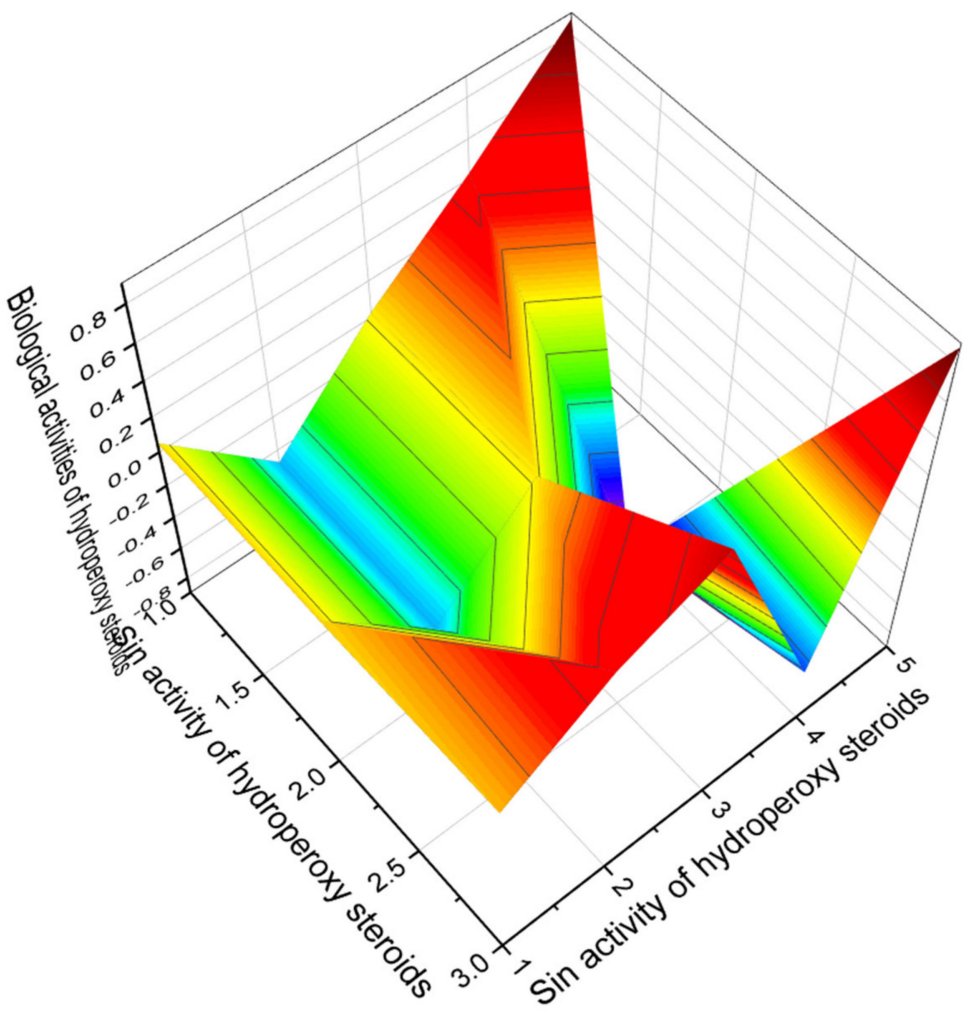

Figure 16. The 3D graph shows the predicted and calculated biological activity of steroid hydroperoxides (compound numbers: 59, 63, and 66) showing the highest degree of confidence, more than 93\%.

\section{Carbon-Bridged Steroids (CBS) and Triterpenoids}

In both natural and synthetic steroids, when an additional ring is formed within the steroid skeleton, through a direct bond between any two carbon atoms (or more) of the steroid ring system or an attached side chain, such steroids (or triterpenoids) are called carbon-bridged steroids [13,200-202].

Of the more than 500 carbon-bridged steroids and triterpenoids studied, we found only twelve lipids that have a confidence level of more than 90 percent as potential lipid regulators. We give their description and their sources in nature below [13,203].

Studying the photoproducts obtained by photochemical processes of vitamin $\mathrm{D}$, the cyclobutane containing derivative 67 was identified [204], and similar secosteroid named toxisterol (68), as a minor transformation product of vitamin D2, has been found in various mushrooms [205]. The chemical structures of steroids and triterpenoids are shown in Figure 17, and the biological activity is shown in Table 7. 

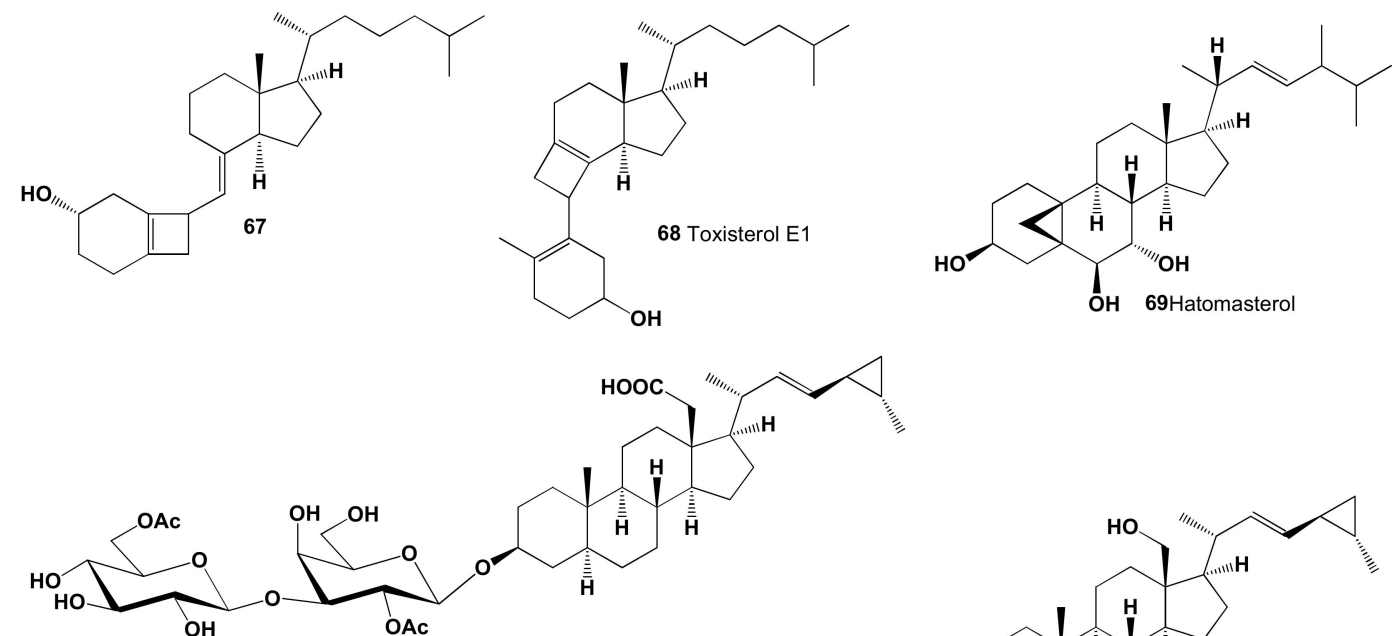

70 Poecillastroside E
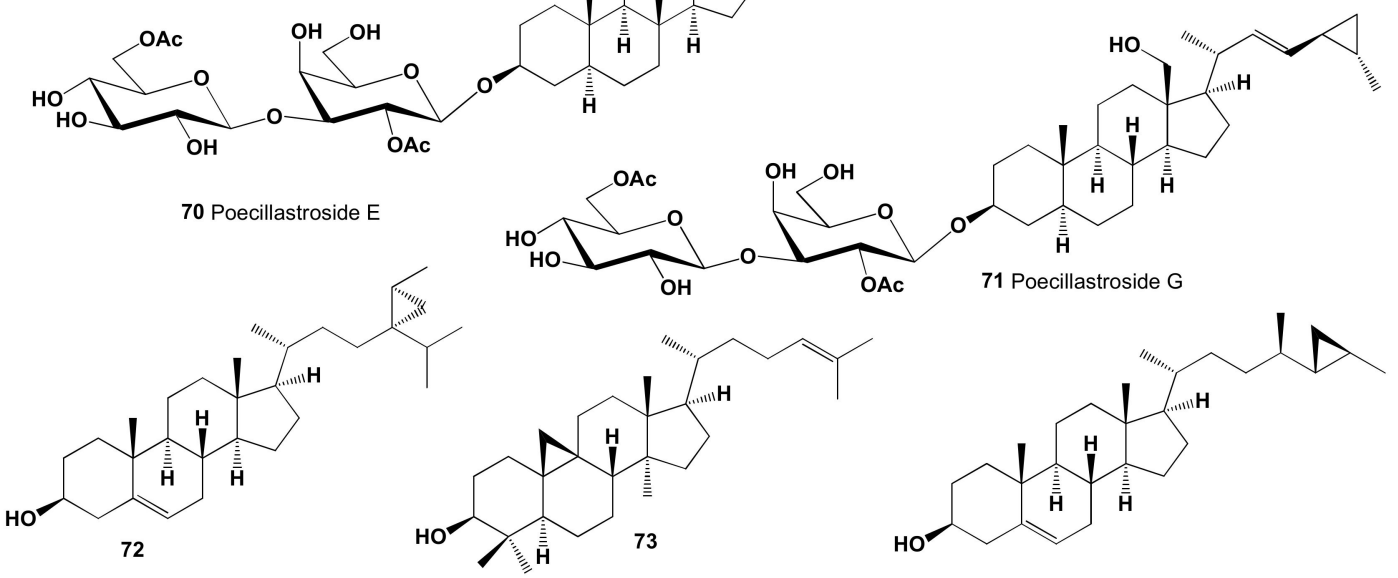

72

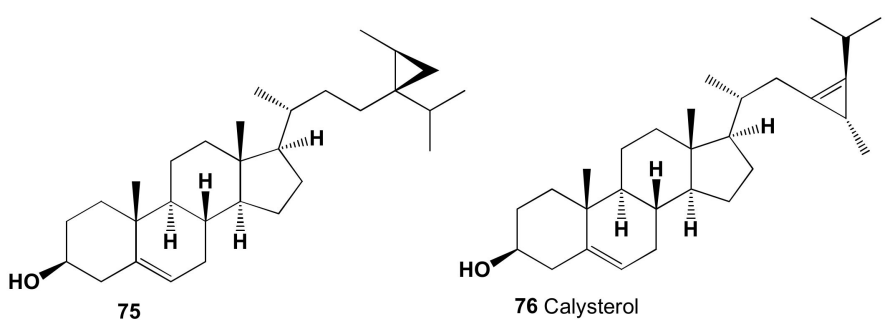

74 Petrosterol

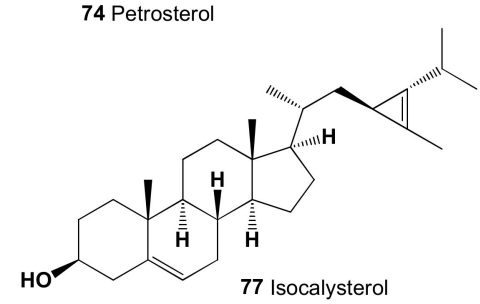

75<smiles>CC(C)CCCC(C)CCCC(C)CCC(=O)O[C@H]1CC[C@@]2(C)C(=CC[C@@H]3[C@@H]2CC[C@@]2(C)[C@H]3CC[C@@H]2[C@H](C)/C=C/[C@@H]2C[C@@H]2C)C1</smiles>

Figure 17. Bioactive CBS derived from fungi and marine sources.

A unique steroid containing a 5,19-cycloergostane skeleton, $(3 \beta, 5 \beta, 6 \beta, 7 \alpha, 22 E, 24 \varsigma)$ 5,19-cycloergost-22-ene-3,6,7-triol, named hatomasterol (69), was found in the extracts of the Okinawan sponge Stylissa sp., and this compound demonstrated cytotoxicity against HeLa cells in vitro [206]. Steroidal saponins named poecillastrosides E (70) and G (71), an oxidized methyl at C-18, into a primary alcohol or a carboxylic acid, have been found in extracts of the Mediterranean deep-sea sponge Poecillastra compressa. Poecillastroside E bearing a carboxylic acid at C-18 showed antifungal activity against Aspergillus fumigatus [207], and other cyclopropyl containing steroids (72) and (75) were found in the methanol extract of the marine sponge Petrosia weinbergi [208]. Cycloart-24-en-3-ol (73) was detected in ethanol extract of marine green alga Cladophora fascicularis [209].

A cytotoxic sterol named petrosterol (74) showed cytotoxic activities on A549, HL60, MCF-7, SK-OV-3, and U937 cancer cell lines, and was present in extracts of several marine sponges such as Vietnamese sponge Ianthella sp., Petrosia spheroïda from the Indian 
Ocean, Halichondria cf. panicea of the Japanese island Iriomote, and Japanese marine sponge Strongylophora corticate [210-213].

Table 7. Predicted biological activities of CBS steroids.

\begin{tabular}{|c|c|c|c|}
\hline No. & Discovered Activity, $(\mathbf{P a})$ * & Reported Activity & Ref. \\
\hline 67 & $\begin{array}{l}\text { Antihypercholesterolemic }(0.902) \\
\text { Hypolipemic }(0.721) \\
\text { Cholesterol synthesis inhibitor }(0.534)\end{array}$ & Activity not studied & \\
\hline 68 & $\begin{array}{l}\text { Antihypercholesterolemic }(0.932) \\
\text { Hypolipemic }(0.695) \\
\text { Cholesterol synthesis inhibitor }(0.588)\end{array}$ & Activity not studied & \\
\hline 69 & $\begin{array}{c}\text { Antineoplastic }(0.915) \\
\text { Antihypercholesterolemic }(0.900) \\
\text { Hypolipemic }(0.897) \\
\text { Apoptosis agonist }(0.892) \\
\text { Antineoplastic (liver cancer) }(0.822) \\
\text { Chemopreventive }(0.776) \\
\text { Atherosclerosis treatment }(0.690) \\
\text { Cytoprotectant }(0.611) \\
\text { Prostate cancer treatment }(0.557) \\
\text { Antimetastatic }(0.528)\end{array}$ & Cytotoxic & [206] \\
\hline 70 & $\begin{array}{l}\text { Antihypercholesterolemic }(0.953) \\
\text { Hypolipemic }(0.758) \\
\text { Lipid metabolism regulator }(0.674) \\
\text { Atherosclerosis treatment }(0.513)\end{array}$ & Antifungal & [207] \\
\hline 71 & $\begin{array}{l}\text { Antihypercholesterolemic }(0.939) \\
\text { Hypolipemic }(0.746) \\
\text { Lipid metabolism regulator }(0.599)\end{array}$ & No activity detected & [207] \\
\hline 72 & $\begin{array}{c}\text { Antihypercholesterolemic }(0.923) \\
\text { Hypolipemic }(0.732) \\
\text { Atherosclerosis treatment }(0.643) \\
\text { Cholesterol synthesis inhibitor }(0.640)\end{array}$ & Activity not studied & \\
\hline 73 & $\begin{array}{c}\text { Hypolipemic }(0.900) \\
\text { Atherosclerosis treatment }(0.689) \\
\text { Cholesterol synthesis inhibitor }(0.671) \\
\text { Antihypercholesterolemic }(0.662) \\
\text { Lipid metabolism regulator }(0.529)\end{array}$ & Activity not studied & \\
\hline 74 & $\begin{array}{c}\text { Antihypercholesterolemic }(0.964) \\
\text { Hypolipemic }(0.849) \\
\text { Antineoplastic }(0.849) \\
\text { Antihyperlipoproteinemic }(0.801) \\
\text { Cholesterol synthesis inhibitor }(0.671) \\
\text { Atherosclerosis treatment }(0.610) \\
\text { Prostate cancer treatment }(0.601)\end{array}$ & $\begin{array}{l}\text { Cytotoxic } \\
\text { Anticancer }\end{array}$ & [211-214] \\
\hline 75 & $\begin{array}{c}\text { Antihypercholesterolemic }(0.923) \\
\text { Hypolipemic }(0.732) \\
\text { Atherosclerosis treatment }(0.643) \\
\text { Cholesterol synthesis inhibitor }(0.640)\end{array}$ & Activity not studied & \\
\hline 76 & $\begin{array}{c}\text { Antihypercholesterolemic }(0.935) \\
\text { Hypolipemic }(0.731) \\
\text { Antihyperlipoproteinemic }(0.689) \\
\text { Cholesterol synthesis inhibitor }(0.600)\end{array}$ & Activity not studied & \\
\hline 77 & $\begin{array}{c}\text { Antihypercholesterolemic }(0.908) \\
\text { Hypolipemic }(0.726) \\
\text { Cholesterol synthesis inhibitor }(0.589) \\
\text { Antihyperlipoproteinemic }(0.587)\end{array}$ & Activity not studied & \\
\hline 78 & $\begin{array}{c}\text { Antihypercholesterolemic }(0.969) \\
\text { Hypolipemic }(0.810) \\
\text { Lipid metabolism regulator }(0.716) \\
\text { Cholesterol synthesis inhibitor }(0.707) \\
\text { Atherosclerosis treatment }(0.586)\end{array}$ & Activity not studied & \\
\hline
\end{tabular}


A rare steroid named calysterol (76), the minor sterol component of the sponge Calyx niceaensis and Petrosia ficiformis, possessing the unique feature of a cyclopropene ring bridging C23,24, and isocalysterol (77), was detected in the same sponge [214-218]. Sterol ester, 24,26 -cyclo- $5 \alpha$-cholest-(22E)-en-3 $\beta-4^{\prime}, 8^{\prime} 12^{\prime}$-trimetyltridecanoate (78), has been isolated from a deep-water marine sponge, Xestospongia sp. [218].

\section{Comparison of Biological Activities of CBS Steroids and Triterpenoids}

Carbon-bridged steroids (CBS) and triterpenoids belong to a rare group of natural hormones found in various natural sources such as green, yellow-green, and red algae, sea sponges, soft corals, ascidians, starfish, and other marine invertebrates. In addition, this group of rare lipids is found in amoebas, fungi, fungal endophytes, and plants [13,203].

We have isolated carbon-bridged steroids presented in Figure 18, which, according to the PASS data, have a confidence level of more than 90 percent. Among this group of lipids, we identified three, numbered $\mathbf{7 0}, \mathbf{7 4}$, and $\mathbf{7 8}$, the activity of which most clearly reflects their regulatory functions of lipid metabolism, with antihypercholesterolemic properties dominating. In addition, these steroids can be used as inhibitors of cholesterol synthesis and as drugs for the treatment of atherosclerosis. The 3D graph demonstrating the predicted and calculated biological activity of carbon-bridged steroids is shown in Figure 18.

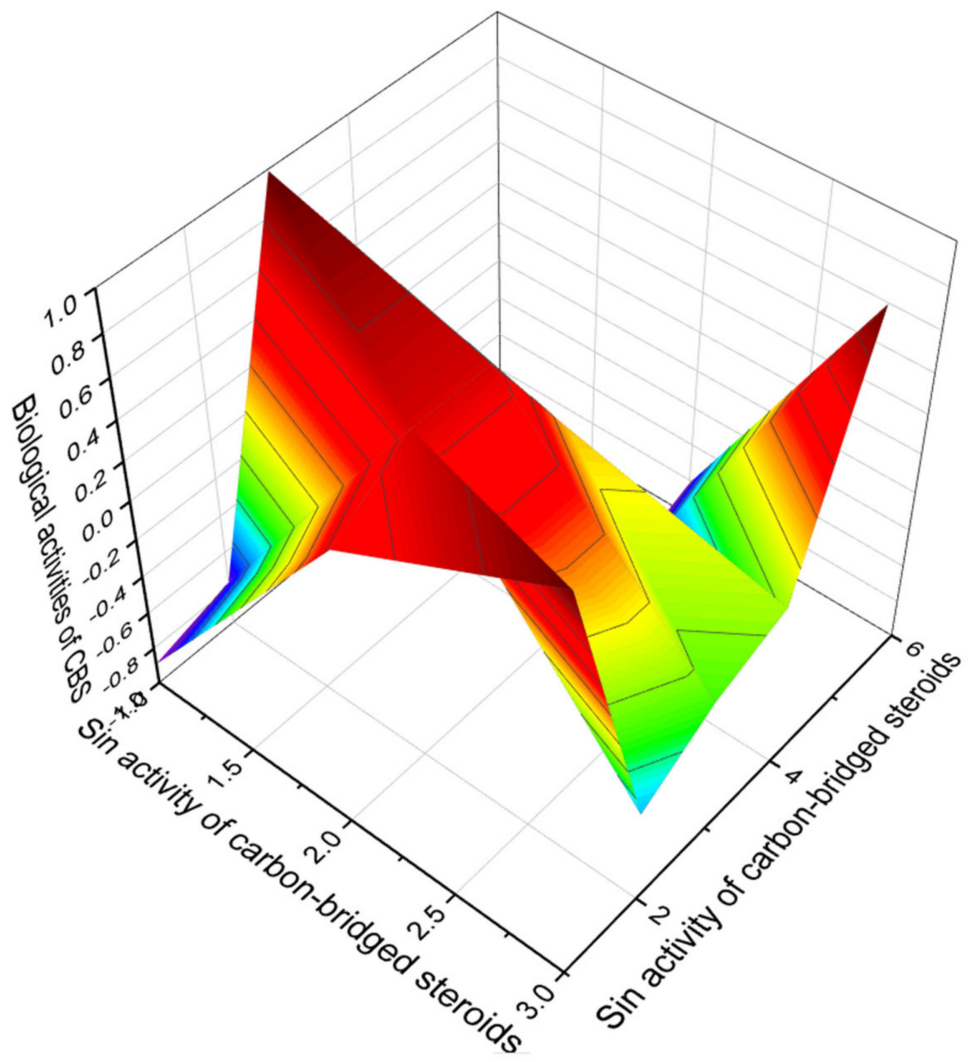

Figure 18. The 3D graph shows the predicted and calculated biological activity of carbon-bridged steroids (compound numbers: 70, 74, and 78) showing the highest degree of confidence, more than $95 \%$

\section{Neo Steroids Derived from Terrestrial and Marine Sources}

Secondary metabolites containing a tertiary butyl group (or tertbutyl unit) are rather rare compounds found in cyanobacteria, plant leaves, fungi, marine invertebrates, and algae [12,219-221].

Neo steroids are a small group of lipids that are synthesized by yeast and fungi and are found in various parts of plants. In recent years, with the improvement of steroid anal- 
ysis methods, they have been found in seaweeds, marine sponges (class Demospongiae), anemones (class Anthozoa), and cucumbers (class Holothuroidea) [12,219].

Two neo steroids (79 and 85) were present in leaves and stems and the pericarp of the fruit and roots of a plant from the family Cucurbitaceae [222], and another sterol, 24-methylene-25-methyl-lathosterol (80), was isolated from aerial parts of the herbaceous plant, Sicyos angulatus [223]. The chemical structures of steroids and triterpenoids are shown in Figure 19, and the biological activity is shown in Table 8.

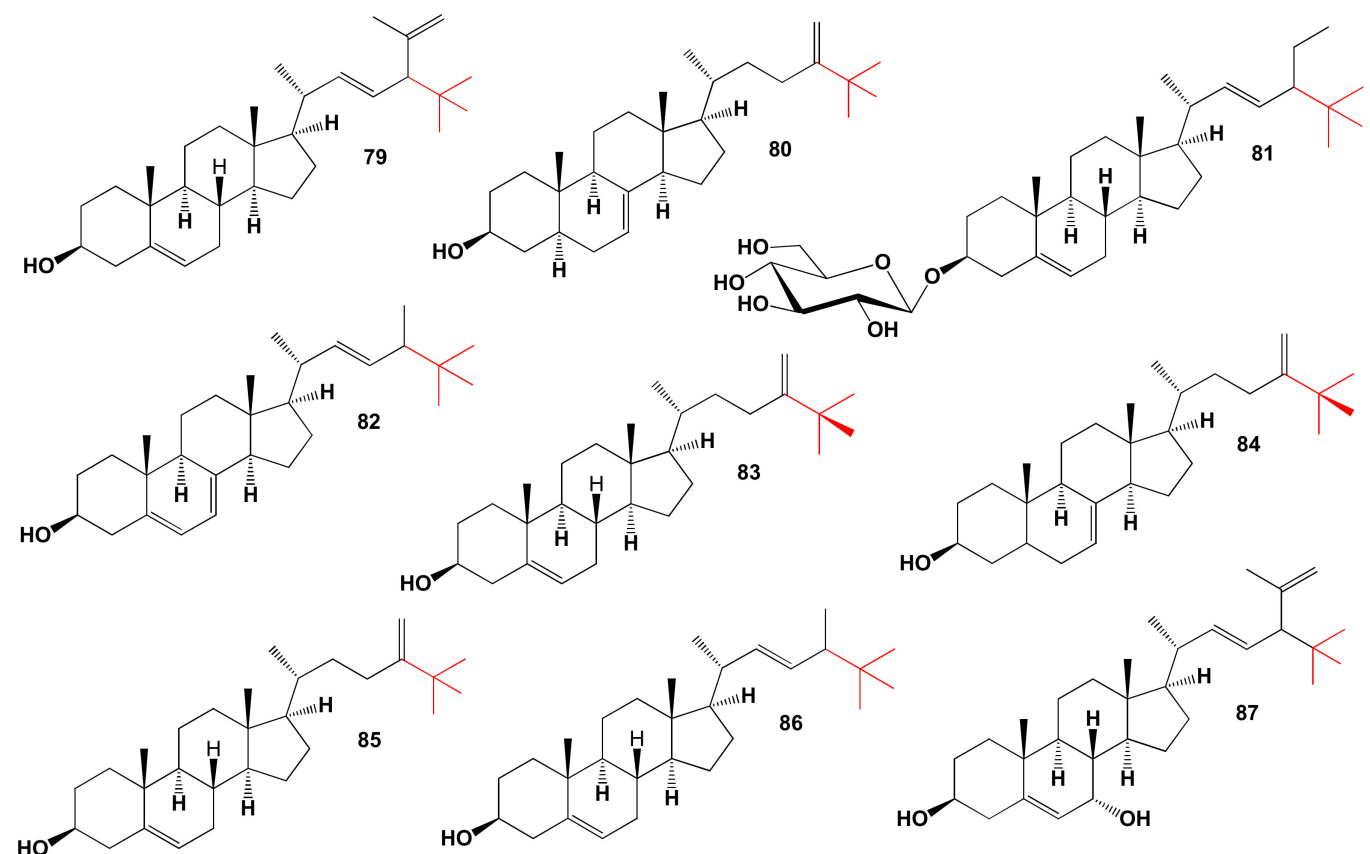

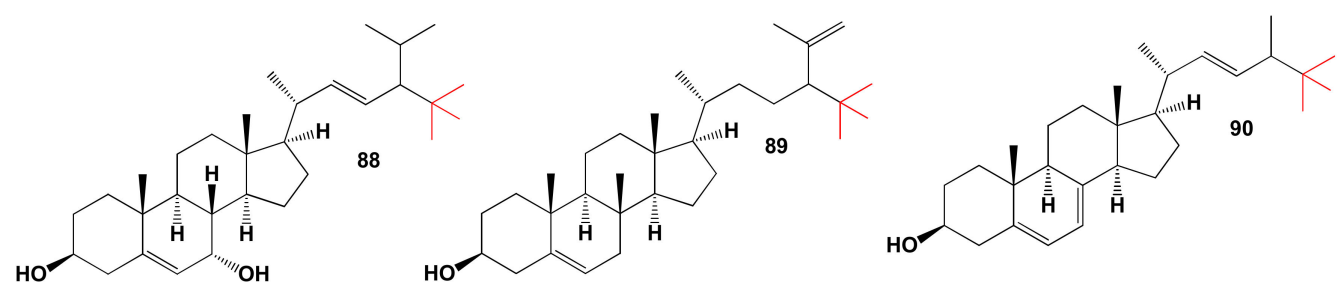

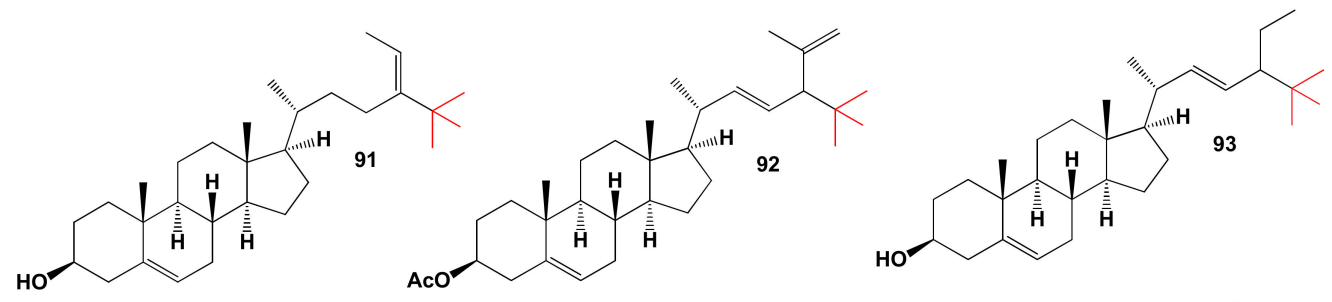

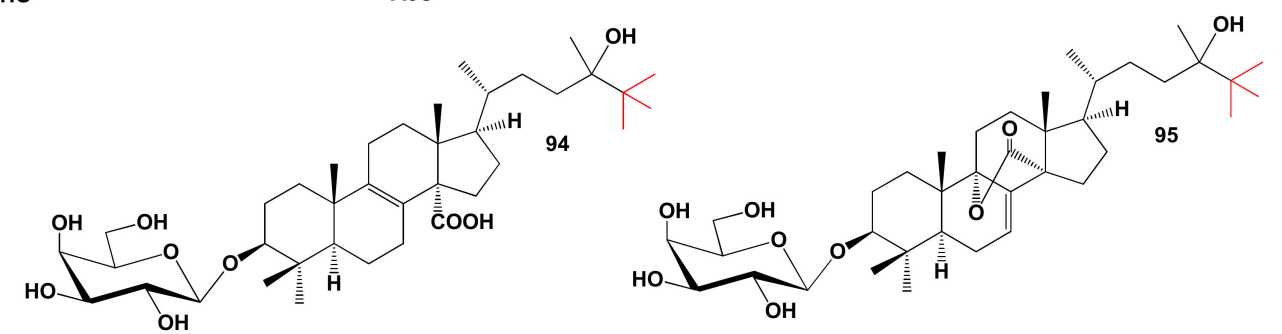

Figure 19. Bioactive neo steroids derived from plants and marine sources.

Aerial parts of the strongly aromatic herb Ocimum basilicum from the Labiatae family, such as seeds, flowers, and roots, are widely used as medicines [224-226]. The leaves and flowers of this plant are used in folk medicine as a tonic and anthelmintic [227]. Leaf tea is used to treat flatulence and dysentery, while the plant's oil may be useful for relieving 
mental fatigue, colds, cramps, rhinitis, and as a first aid for treating wasp stings and snake bites $[227,228]$. A species of this plant from Pakistan contains $(22 \mathrm{E})-24 \xi$-ethyl-25methylcholesta-5,22-diene-3 $\beta$-ol-3-O-D-gluco-pyranoside (81) [229].

Three neo steroids $(82,83$ and 86 ) have been isolated from this auxotroph mutant Saccharomyces cerevisiae strain GL7 using appropriate substrates for biosynthesis [230]. The sterol C24-methyl transferase from Trypanosoma brucei TbSMT1 produces 24-methyl sterols that serve as substrates for 24-dimethyl sterols that contain a $\Delta 25(27)$-bond, and the neo steroid (84) was isolated from the extract S. cerevisiae [231]. Topsentinols C (87) and $\mathrm{E}$ (88) contain a tertiary butyl group in steroids, and these neo steroids were obtained from the Okinawan marine sponge Topsentia sp. [232,233]. (3ß,24E)-25-Methylstigmasta5,24(28)-dien-3-ol (89) and axinyssasterol (90) were identified from a marine sponge Pseudoaxinyssa sp. [234].

Neo steroid $(3 \beta, 22 \mathrm{E}, 24 \xi)$-28,28-dimethyl-stigmasta-5,22,25-trien-3-ol acetate (91) and $(3 \beta, 22 \mathrm{E})-25$-methyl-stigmasta-5,22-dien-3-ol (92) were obtained from an ethanol extract of the sponge Halichondria sp. $[235,236]$, and the compound (93) was also found in specimens of the sponge T. aplysinoides from the inshore waters of Sri Lanka [236]. The antimicrobial halistanol (93) was isolated from the Okinawan sponge Halichondria cf. moorei more than 25 years ago [237].

Table 8. Biological activities of neo steroids.

\begin{tabular}{|c|c|c|c|}
\hline No. & Discovered Activity, $(\mathrm{Pa})$ * & Reported Activity & Ref. \\
\hline 79 & $\begin{array}{l}\text { Antihypercholesterolemic }(0.964) \\
\text { Atherosclerosis treatment }(0.717)\end{array}$ & Activity not studied & \\
\hline 80 & Antihypercholesterolemic (0.956) & Activity not studied & \\
\hline 81 & $\begin{array}{l}\text { Antihypercholesterolemic }(0.989) \\
\text { Hypolipemic }(0.808)\end{array}$ & Activity not studied & \\
\hline 82 & $\begin{array}{l}\text { Antihypercholesterolemic }(0.960) \\
\text { Atherosclerosis treatment }(0.683)\end{array}$ & Activity not studied & \\
\hline 83 & $\begin{array}{c}\text { Antihypercholesterolemic }(0.961) \\
\text { Cholesterol synthesis inhibitor }(0.745)\end{array}$ & Activity not studied & \\
\hline 84 & $\begin{array}{c}\text { Antihypercholesterolemic }(0.956) \\
\text { Cholesterol synthesis inhibitor }(0.747)\end{array}$ & Activity not studied & \\
\hline 85 & Antihypercholesterolemic (0.964) & Activity not studied & \\
\hline 86 & Antihypercholesterolemic (0.969) & Activity not studied & \\
\hline 87 & $\begin{array}{l}\text { Antihypercholesterolemic }(0.952) \\
\text { Atherosclerosis treatment }(0.710)\end{array}$ & Activity not studied & \\
\hline 88 & $\begin{array}{l}\text { Antihypercholesterolemic }(0.965) \\
\text { Atherosclerosis treatment }(0.677)\end{array}$ & Activity not studied & \\
\hline 89 & Antihypercholesterolemic (0.969) & Activity not studied & \\
\hline 90 & $\begin{array}{l}\text { Antihypercholesterolemic }(0.965) \\
\text { Atherosclerosis treatment }(0.700)\end{array}$ & Activity not studied & \\
\hline 91 & Antihypercholesterolemic (0.969) & Activity not studied & \\
\hline 92 & $\begin{array}{l}\text { Antihypercholesterolemic }(0.962) \\
\text { Atherosclerosis treatment }(0.704) \\
\text { Lipid metabolism regulator }(0.702)\end{array}$ & Activity not studied & \\
\hline
\end{tabular}


Table 8. Cont.

\begin{tabular}{|c|c|c|c|}
\hline No. & Discovered Activity, $(\mathrm{Pa})$ * & Reported Activity & Ref. \\
\hline 93 & $\begin{array}{l}\text { Antihypercholesterolemic }(0.974) \\
\text { Antimicrobial treatment }(0.717)\end{array}$ & Antimicrobial & [237] \\
\hline 94 & $\begin{array}{c}\text { Antihypercholesterolemic }(0.961) \\
\text { Antineoplastic }(0.863) \\
\text { Anticarcinogenic }(0.828) \\
\text { Lipid metabolism regulator }(0.747) \\
\text { Antimetastatic }(0.590)\end{array}$ & Anticancer & {$[238,239]$} \\
\hline 95 & $\begin{array}{c}\text { Antihypercholesterolemic }(0.936) \\
\text { Antineoplastic }(0.870) \\
\text { Anticarcinogenic }(0.807) \\
\text { Antimetastatic }(0.598)\end{array}$ & Anticancer & {$[238,239]$} \\
\hline
\end{tabular}

The Atlantic tropical sponge Erylus goffrilleri contains unusual lanostane glycosides, erylosides R (94) and T (95), and the same glycosides were isolated from the Caribbean sponge E. goffrilleri. Both eryloside glycosides R and T exhibit cytotoxic activities against Ehrlich carcinoma tumor cells [238,239].

\section{Comparison of Biological Activities of Neo Steroids}

Neo steroids are a rare group of naturally occurring lipid molecules that exhibit high levels and a wide range of activities. The chemical structures shown in Figure 19 have been found in plant and marine invertebrate extracts. According to PASS data, neo steroids show a high confidence level of up to 98.9 percent, with antihypercholesterolemic activity being dominant. In addition, virtually all neo steroids are cholesterol synthesis inhibitors and can be used to treat atherosclerosis and related diseases.

Of the seventeen neo steroids, we have selected four that show a high confidence level of 96.9 to 98.9 percent. Figure 20 demonstrates the 3D graph and shows the predicted and calculated biological activity of neo steroids (compound numbers: $\mathbf{8 1}, \mathbf{8 6}, \mathbf{8 9}$, and 93) showing the highest degree of confidence, more than $96.9 \%$.

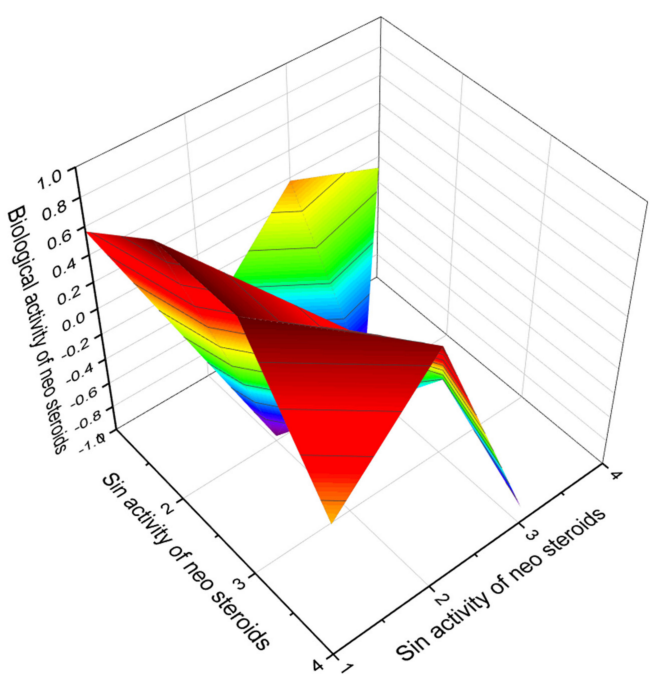

Figure 20. The $3 \mathrm{D}$ graph shows the predicted and calculated biological activity of neo steroids (compound numbers: $\mathbf{8 1}, \mathbf{8 6}, \mathbf{8 9}$, and $\mathbf{9 3}$ ) showing the highest degree of confidence, more than $96.9 \%$.

\section{Miscellaneous Steroids and Triterpenoids Derived from Marine Sources}

In this section, we have collected steroids that do not belong to the first six groups of triterpenoids but show high antihypercholesterolemic activity. Mostly, the steroids shown in Figure 20 are found in soft corals collected in various regions of the world's oceans. 
An interesting question is why from coral? The fact is that, by studying the activities of various marine organisms, we concluded that corals or their fungal endophytes synthesize many biologically active metabolites. It is well known that corals are associated with many microscopic fungi, so a reasonable question arises: what synthesizes bioactive molecules in corals? Whether they do so themselves or their fungal endophytes or bacteria is a question that remains open [240-242].

Cytotoxic steroid called stereonsteroid G (96) was isolated from the methylene chloride extract of the Formosan soft coral Stereonephthya crystalliana. The extract of this coral showed significant cytotoxicity against A549, HT-29 and P-388 cancer cells in vitro [243]. The chemical structures of steroids and triterpenoids are shown in Figure 21, and the biological activity is shown in Table 9 .

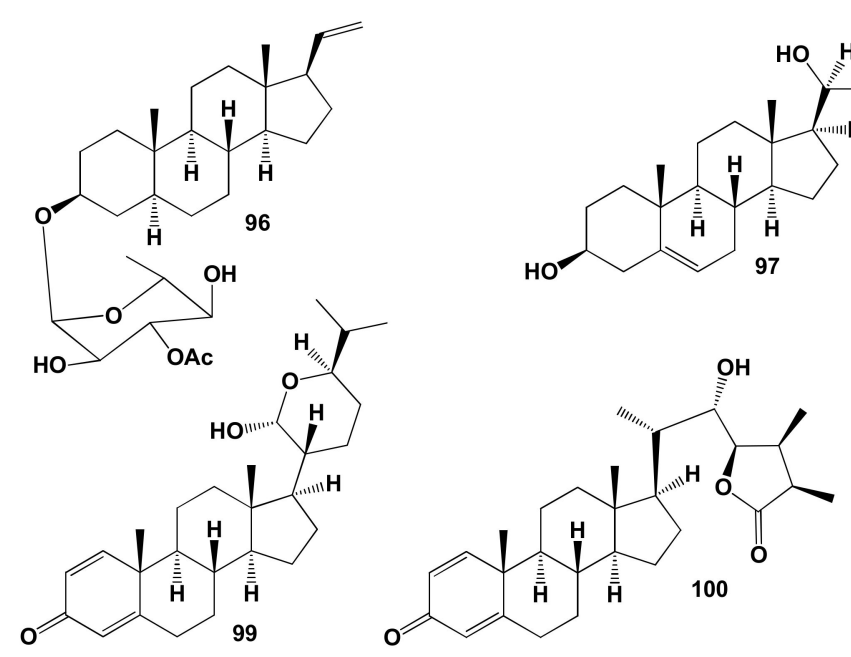

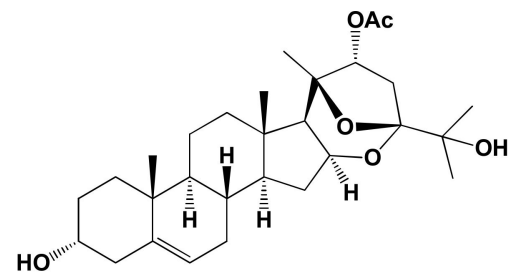

98

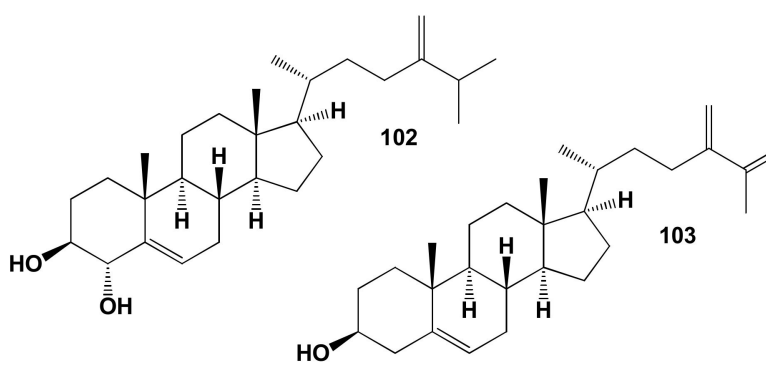

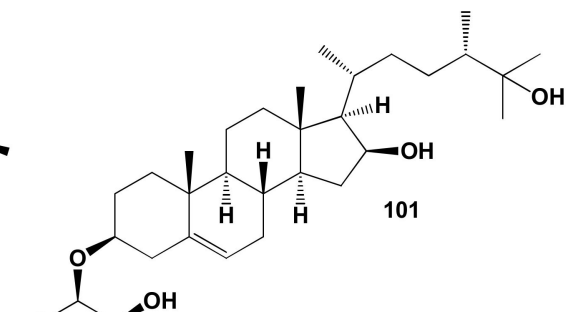

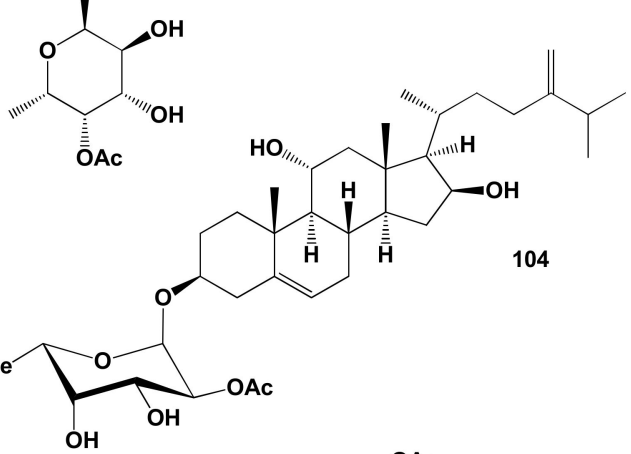
$\mathrm{OH}$

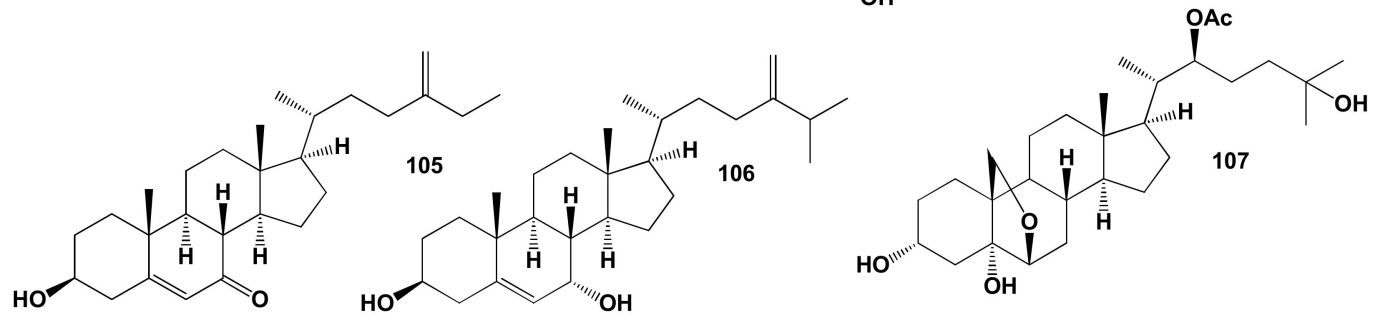

Figure 21. Bioactive steroids derived from soft corals.

Trihydroxy sterol, pregna-5-ene-3,20,21-triol (97), has been isolated from the Gulf of California gorgonian Muricea cf. austera [244], and a rare spiroketal steroid, 22-acetoxy3,25-dihydroxy-16,24,20-24-bisepoxy-(3,16,20S,22R,24S)-cholest-5-ene (98) was found in extracts of the Indian Ocean gorgonian, Gorgonella umbraculum [245]. The cholestane class steroidal hemiacetals named anastomosacetal A (99) was obtained from the gorgonian coral Euplexaura anastomosans, collected off the shore of Keomun Island, South Sea Korea [246], and petasitosterone B (100) was isolated from a Formosan marine soft coral Umbellulifera petasites [247]. Petasitosterone B (100) displayed inhibitory activity against the proliferation 
of a limited panel of cancer MOLT-4 and DLD-1 cell line. Steroidal glycoside (101) was isolated from water-methanol solutions of the soft coral Sinularia gibberosa [248], and steroid 102 was found in the methanol extract of the Vietnamese soft coral Sinularia nanolobata [249]. The minor sterol $\mathbf{1 0 3}$ was isolated from the soft coral extract of the genus Sinularia, and it was synthesized [250]. Steroid named crassarosteroside A (104) was obtained from Sinularia granosa and S. crassa soft coral extracts [251,252], compound $\mathbf{1 0 5}$ has been isolated from Sinularia conferta and S. nanolobata [253,254], and metabolite 106 was detected in $\mathrm{MeOH}$ extract of the soft coral S. cruciata [255]. Oxysterol (107) was detected in extracts of octocoral of the genus Gorgonia from the eastern Pacific, Panama [256].

Table 9. Biological activities of soft coral steroids.

\begin{tabular}{|c|c|c|c|}
\hline No. & Discovered Activity, $(\mathrm{Pa})$ * & Reported Activity & Ref. \\
\hline 96 & $\begin{array}{c}\text { Neuroprotector }(0.983) \\
\text { Antihypercholesterolemic }(0.919) \\
\text { Acute neurologic disorders treatment }(0.636) \\
\text { Hypolipemic }(0.626)\end{array}$ & Anticancer & [243] \\
\hline 97 & $\begin{array}{c}\text { Antihypercholesterolemic }(0.954) \\
\text { Neuroprotector }(0.754) \\
\text { Hypolipemic }(0.704)\end{array}$ & Activity not studied & \\
\hline 98 & $\begin{array}{c}\text { Antihypercholesterolemic }(0.927) \\
\text { Neuroprotector }(0.773) \\
\text { Hypolipemic }(0.584)\end{array}$ & Activity not studied & \\
\hline 99 & Antihypercholesterolemic (0.962) & Activity not studied & \\
\hline 100 & $\begin{array}{c}\text { Antihypercholesterolemic }(0.918) \\
\text { Anti-inflammatory }(0.903) \\
\text { Antineoplastic }(0.875) \\
\text { Proliferative diseases treatment }(0.856) \\
\text { Atherosclerosis treatment }(0.618)\end{array}$ & $\begin{array}{l}\text { Anti-inflammatory } \\
\text { Anticancer }\end{array}$ & [247] \\
\hline 101 & $\begin{array}{l}\text { Antihypercholesterolemic }(0.976) \\
\text { Hypolipemic }(0.735) \\
\text { Lipid metabolism regulator }(0.707)\end{array}$ & Activity not studied & \\
\hline 102 & $\begin{array}{c}\text { Antihypercholesterolemic }(0.920) \\
\text { Hypolipemic }(0.798) \\
\text { Atherosclerosis treatment }(0.637) \\
\text { Hyperparathyroidism treatment }(0.523)\end{array}$ & Activity not studied & \\
\hline 103 & $\begin{array}{l}\text { Antihypercholesterolemic }(0.955) \\
\text { Atherosclerosis treatment }(0.596)\end{array}$ & Activity not studied & \\
\hline 104 & $\begin{array}{c}\text { Proliferative diseases treatment }(0.967) \\
\text { Chemopreventive }(0.958) \\
\text { Antihypercholesterolemic }(0.947) \\
\text { Anticarcinogenic }(0.907) \\
\text { Antineoplastic }(0.902) \\
\text { Hypolipemic }(0.781) \\
\text { Atherosclerosis treatment }(0.609)\end{array}$ & Anticancer & [251] \\
\hline 105 & $\begin{array}{l}\text { Antihypercholesterolemic }(0.957) \\
\text { Hypolipemic }(0.809) \\
\text { Atherosclerosis treatment }(0.592)\end{array}$ & Activity not studied & \\
\hline 106 & $\begin{array}{c}\text { Antihypercholesterolemic }(0.955) \\
\text { Hypolipemic }(0.878) \\
\text { Atherosclerosis treatment }(0.658)\end{array}$ & Activity not studied & \\
\hline 107 & $\begin{array}{l}\text { Neuroprotector }(0.938) \\
\text { Antihypercholesterolemic }(0.912) \\
\text { Atherosclerosis treatment }(0.548)\end{array}$ & Activity not studied & \\
\hline
\end{tabular}

\section{Comparison of Biological Activities of Soft Coral Steroids}

The chemical and structural diversity of soft corals sterols and triterpenoids is well known and has been documented in several review articles in the literature [128,130,257-261]. PASS analysis shows that the steroids in Figure 21 synthesized by soft corals are indeed of interest due to their high anticholesterol activity. Both the biological activities found using PASS and those 
obtained experimentally coincide. In addition, we have identified three steroids, numbered 99, 101, and 104, which demonstrate antihypercholesterolemic activity with a high degree of certainty. Figure 22 shows a 3D graph of predicted and calculated biological activity of these steroids.

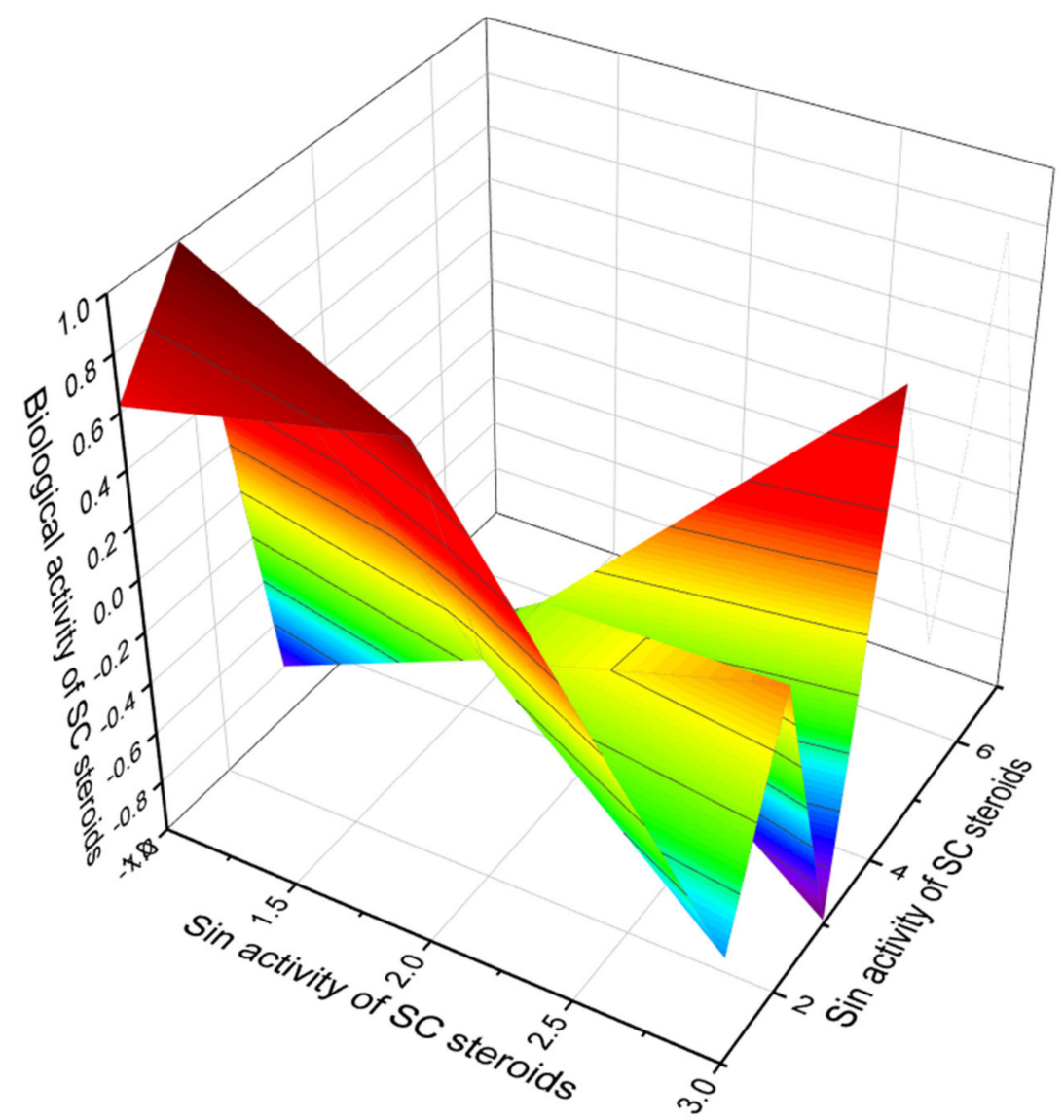

Figure 22. The 3D graph shows the predicted and calculated biological activity of soft coral steroids (compound numbers: 99, 101 and 104) showing the highest degree of confidence, more than $96.2 \%$.

\section{Synthetic and Semi-Synthetic Steroids and Triterpenoids and Comparison of Their Biological Activities}

Steroid hormones and triterpenoids belong to the group of physiologically active substances (sex hormones, corticosteroids, etc.) that regulate vital processes in vertebrates and many species of invertebrates and humans [262-265]. They are regulators of the fundamental vital processes of a multicellular organism-coordinated growth, differentiation, reproduction, adaptation, and behavior [266-268]. For more than 90 years, steroid hormones and triterpenoids have been the subject of close attention of chemists since synthetic analogues have long replaced natural steroids and triterpenoids [269-273]. It is known that semi-synthetic or synthetic steroid hormones have properties that steroids do not have, isolated from natural sources. In this section, we present synthetic and semi-synthetic steroids and triterpenoids that contain heteroatoms and do not exist in nature but demonstrate activities that are necessary for pharmacologists and physicians.

\subsection{Bioactive Epithio Steroids and Triterpenoids}

Anabolic steroids are pharmacological drugs that mimic the effect of the male sex hormone testosterone and its derivatives [274-276]. Anabolic steroids accelerate the synthesis of protein within cells, which leads to a pronounced hypertrophy of the muscle tissue, because of which, they have found wide application in sports medicine and bodybuilding [277-279]. 
Semi- and/or synthetic epithio steroids represent a rare group of bioactive lipids, since they are hydrophobic molecules insoluble in water, which are not found in nature. Epithio steroids have been reported to possess a variety of cytotoxic activities, and they are widely used as anticancer agents. The thiirane group is an important substance and shows some promising biological activities. Steroids containing an epithio group in positions 2 and 3 are anabolic steroids and are widely known and used in sports medicine. Representatives of this group of steroids are of great interest for pharmaceutical chemistry and medicine [280-286]. The most widely known are such epithio steroids that are used in sports pharmacology and medicine: epistane $(108,2 \alpha, 3 \alpha$-epithio- $17 \alpha$-methyl- $5 \alpha-$ androstan-17 $\beta$-ol), epitiostanol (109, $2 \alpha, 3 \alpha$-epithio- $5 \alpha$-androstan-17 $\beta$-ol), a known potent antiestrogenic and antitumor agent, and hemapolin (110, $2 \beta, 3 \beta$-epithio- $17 \alpha$-methyl- $5 \alpha$ androstan-17 $\beta$-ol) $[282,283,287-291]$. The chemical structures of epithio steroids are shown in Figure 23 and the biological activities are shown in Table 10. Presented in Figure 24, the anabolic $2 \alpha, 3 \alpha$-epithio chlostane (111) shown dominant anticancer activity, and steroid (112) demonstrated dominant properties as an antisecretory agent with $96.7 \%$ confidence and acts as an estrogen antagonist with $94.6 \%$ confidence.

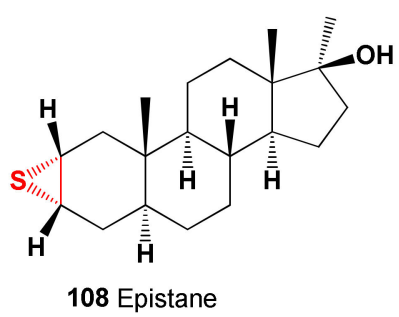

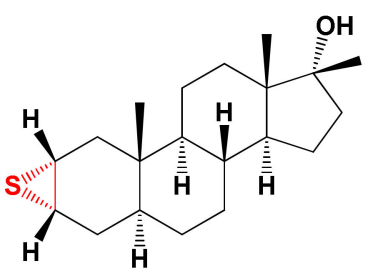

109 Epitiostanol

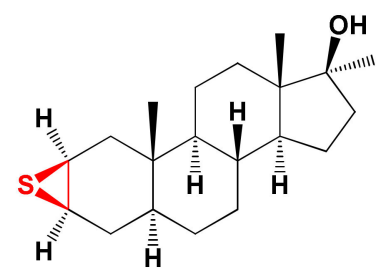

110

Hemapolin

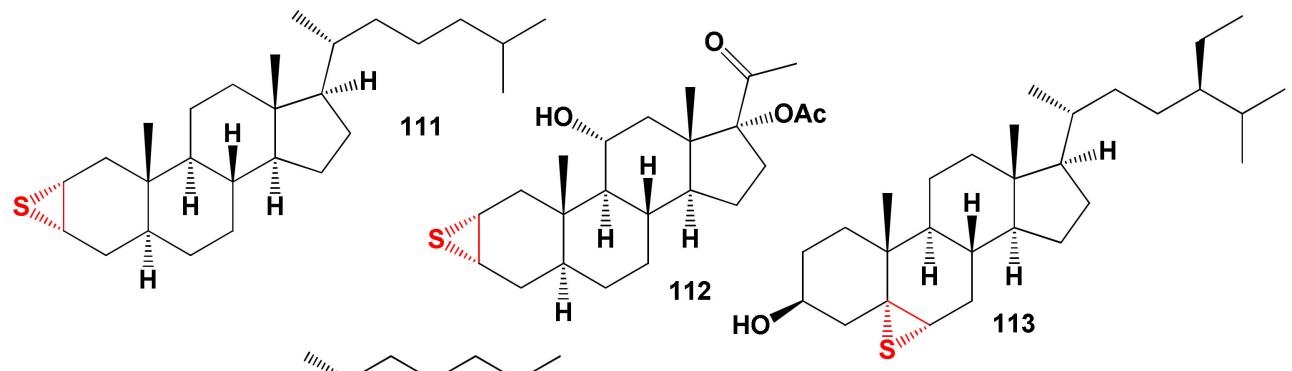

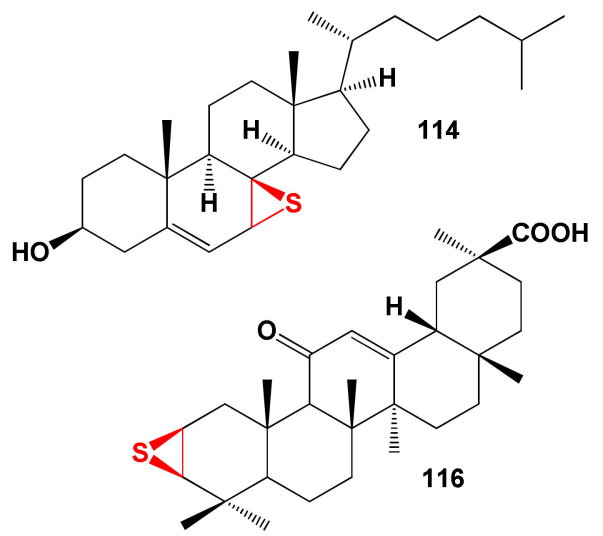

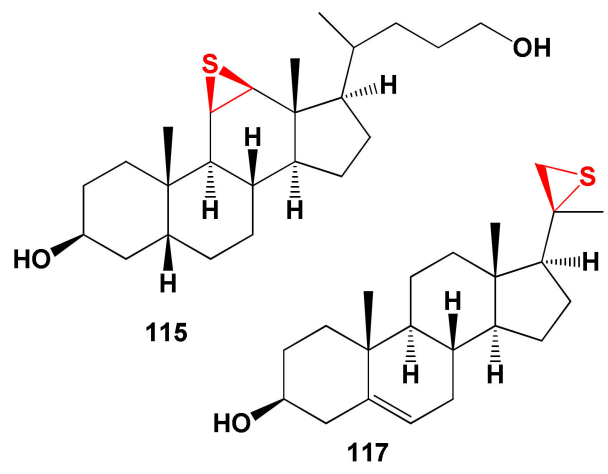

Figure 23. Bioactive epithio steroids and triterpenoid containing the thiirane group in a variety of steroid backbones. 


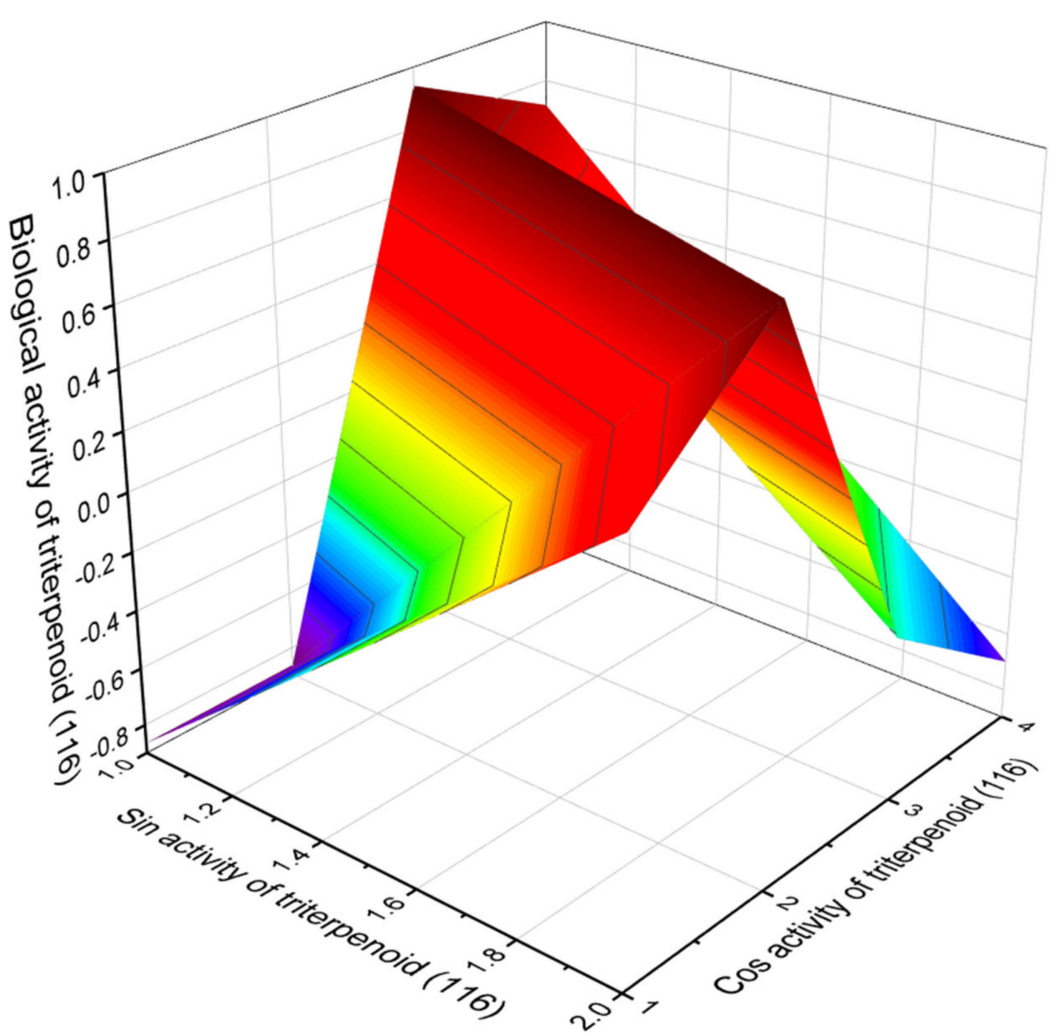

Figure 24. The 3D graph shows the predicted and calculated biological activity of triterpenod (116), which was synthesized from a natural sample of $18 \beta$-glycyrrhetinic acid, showing the highest degree of confidence as lipid metabolism regulator properties, more than $95.4 \%$. 18 $\beta$-Glycyrrhetinic acid is a $\beta$-amyrin-type pentacyclic triterpenoid derived from the herb licorice (Glycyrrhiza glabra). It is known and used as a flavoring agent and masks the bitter taste of drugs such as aloe and quinine; it is also effective in the treatment of peptic ulcer disease and has some additional pharmacological properties with possible antiviral, antifungal, antiprotozoal, and antibacterial effects.

Epithio steroids (113-115 and 117) and are cholesterol antagonists, and the anticancer triterpenoid (116), which was synthesized from a natural sample of $18 \beta$-glycyrrhetinic acid [292,293], shows lipid metabolism regulator properties.

Table 10. Biological activities of epithio steroids.

\begin{tabular}{|c|c|c|c|}
\hline No. & Discovered Activity, $(\mathrm{Pa})$ * & Reported Activity & Ref. \\
\hline 108 & $\begin{array}{c}\text { Antineoplastic }(0.964) \\
\text { Antisecretoric }(0.948) \\
\text { Estrogen antagonist }(0.860) \\
\text { Cardiotonic }(0.729) \\
\text { Prostate disorders treatment }(0.709) \\
\text { Neuroprotector }(0.723) \\
\text { Bone diseases treatment }(0.693) \\
\text { Antineoplastic (breast cancer) }(0.598)\end{array}$ & $\begin{array}{l}\text { Anti-breast cancer } \\
\text { Estrogen receptor } \\
\text { antagonist }\end{array}$ & [294] \\
\hline 109 & $\begin{array}{c}\text { Antineoplastic }(0.966) \\
\text { Antisecretoric }(0.952) \\
\text { Estrogen antagonist }(0.832) \\
\text { Anti-inflammatory }(0.754) \\
\text { Prostate disorders treatment }(0.736) \\
\text { Prostatic (benign) hyperplasia treatment } \\
(0.673)\end{array}$ & Estrogen antagonist & [294] \\
\hline
\end{tabular}


Table 10. Cont.

\begin{tabular}{|c|c|c|c|}
\hline No. & Discovered Activity, $(\mathrm{Pa})$ * & Reported Activity & Ref. \\
\hline 110 & $\begin{array}{c}\text { Antineoplastic }(0.966) \\
\text { Antisecretoric }(0.952) \\
\text { Estrogen antagonist }(0.832) \\
\text { Anti-inflammatory }(0.754) \\
\text { Prostate disorders treatment }(0.736) \\
\text { Prostatic (benign) hyperplasia treatment } \\
(0.673)\end{array}$ & Estrogen antagonist & [294] \\
\hline 111 & $\begin{array}{c}\text { Antineoplastic }(0.932) \\
\text { Antihypercholesterolemic }(0.759) \\
\text { Bone diseases treatment }(0.729) \\
\text { Hypolipemic }(0.676) \\
\text { Estrogen antagonist }(0.660)\end{array}$ & Anabolic & [294] \\
\hline 112 & $\begin{array}{l}\text { Antisecretoric }(0.967) \\
\text { Estrogen antagonist }(0.946) \\
\text { Antineoplastic }(0.939) \\
\text { Anabolic }(0.823)\end{array}$ & Anabolic & [284-286] \\
\hline 113 & $\begin{array}{c}\text { Cholesterol antagonist }(0.933) \\
\text { Antihypercholesterolemic }(0.929) \\
\text { Hypolipemic }(0.818) \\
\text { Estrogen antagonist }(0.443)\end{array}$ & $\begin{array}{l}\text { Antiseptic, } \\
\text { Germicidal, } \\
\text { Fungicidal }\end{array}$ & [294] \\
\hline 114 & $\begin{array}{c}\text { Cholesterol antagonist }(0.946) \\
\text { Antihypercholesterolemic }(0.930) \\
\text { Hypolipemic }(0.781) \\
\text { Estrogen antagonist }(0.465)\end{array}$ & $\begin{array}{l}\text { Antiseptic, } \\
\text { Germicidal, } \\
\text { Fungicidal }\end{array}$ & [294] \\
\hline 115 & $\begin{array}{c}\text { Cholesterol antagonist }(0.932) \\
\text { Antihypercholesterolemic }(0.900) \\
\text { Cardiotonic }(0.886) \\
\text { Choleretic }(0.871) \\
\text { Atherosclerosis treatment }(0.838) \\
\text { Antineoplastic }(0.775) \\
\text { Hypolipemic }(0.746) \\
\text { Estrogen antagonist }(0.611)\end{array}$ & DOCA inhibitor & [294] \\
\hline 116 & $\begin{array}{c}\text { Lipid metabolism regulator }(0.954) \\
\text { Antineoplastic }(0.924) \\
\text { Apoptosis agonist }(0.869) \\
\text { Estrogen antagonist }(0.505)\end{array}$ & Anticancer & {$[292,295]$} \\
\hline 117 & $\begin{array}{c}\text { Cholesterol antagonist }(0.916) \\
\text { Antihypercholesterolemic }(0.836) \\
\text { Hypolipemic }(0.801)\end{array}$ & Activity not studied & \\
\hline
\end{tabular}

\subsection{Bioactive Selena Steroids}

Selenium is an essential metalloid, and it is one of the most necessary trace elements for humans [296]. Selenium occupies an important place in the regulation of metabolism in humans, and therefore, it is necessary to monitor its presence in consumed foods $[297,298]$. The Allium and Brassica families as well as Brazil nuts, mushrooms (shiitake and white mushrooms), beans, chia seeds, brown rice, sunflower, sesame and flax seeds, and cabbage and spinach contain high enough selenium and organoselenium concentrations $[299,300]$.

There are also many excellent reviews in the literature, which are devoted to the biological role and functions of organoselenium compounds [301-304]. Apparently, selena steroids are the main group of the essential metalloids that have been synthesized over the past 50 years, and approximately 300 have been synthesized [304-309].

The selena steroids numbered 118, 119, 124, 125, 126, and 127 show dominant antihypercholesterolemic activity with a low degree of confidence from 90.5 to $91.2 \%$, although 
for steroid number 128, the confidence was $95.3 \%$. For another group, the selena steroids numbered 120, 121, 122, and 123, the dominant properties are hyperlipemia, treatment of atherosclerosis, and treatment of lipoprotein disorders with a strong degree of confidence up to $99.6 \%$. The chemical structures of steroids are shown in Figure 25, and the biological activity is shown in Table 11. Figure 26 shows the 3D graph the predicted and calculated biological activity of the selena steroids numbered 120, 121, and 122 with dominant properties as hyperlipemia and treatment of atherosclerosis.

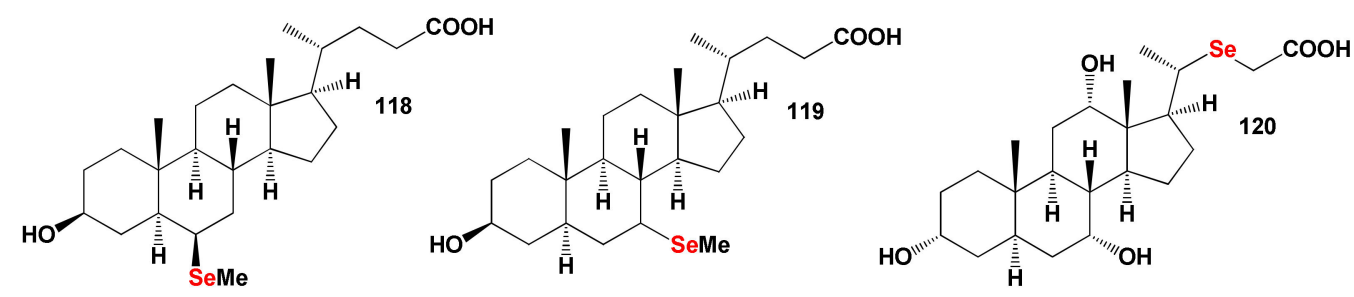

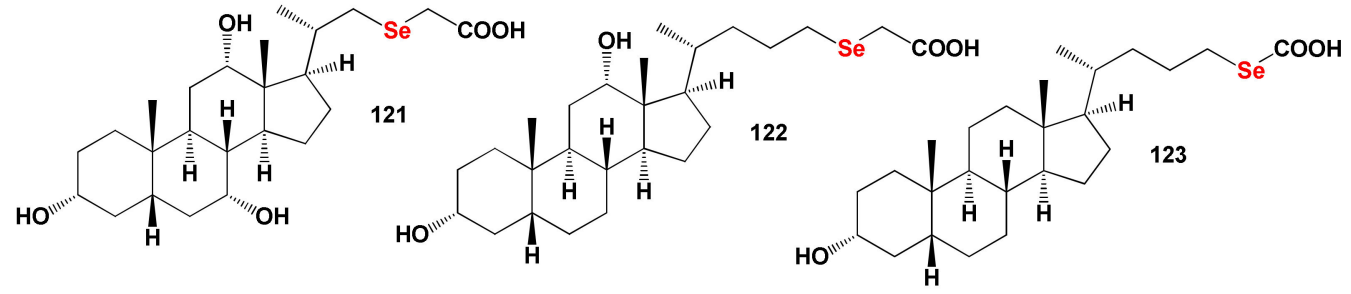

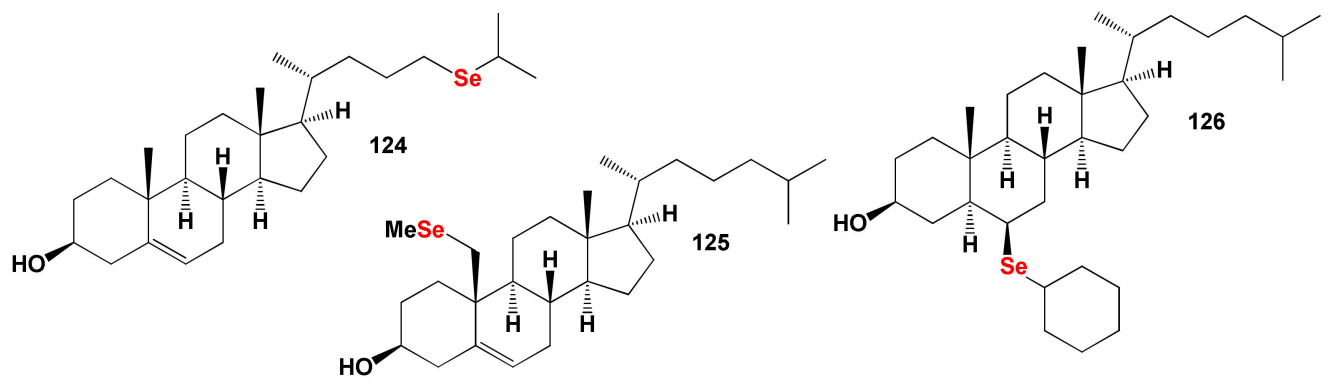

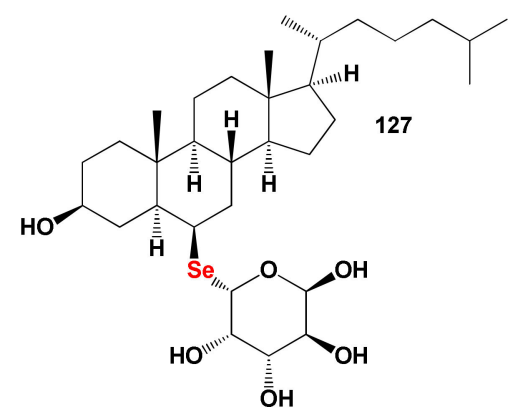

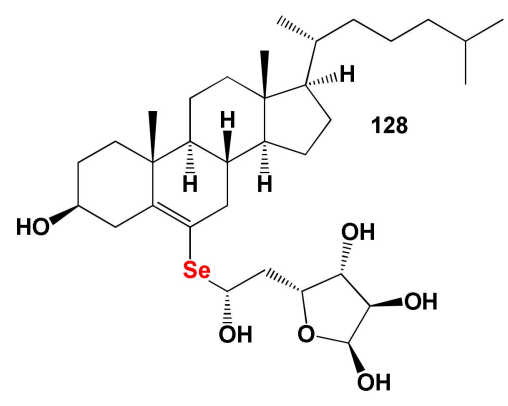

Figure 25. Bioactive synthetic selena steroids. 
Table 11. Biological activities of the selena steroids.

\begin{tabular}{|c|c|c|c|}
\hline No. & Discovered Activity, (Pa) * & Reported Activity & Ref. \\
\hline 118 & Antihypercholesterolemic (0.905) & Activity not studied & \\
\hline 119 & $\begin{array}{c}\text { Choleretic (0.909) } \\
\text { Antihypercholesterolemic (0.905) }\end{array}$ & Activity not studied & \\
\hline 120 & $\begin{array}{c}\text { Hypolipemic }(0.995) \\
\text { Atherosclerosis treatment }(0.991) \\
\text { Lipoprotein disorders treatment }(0.982) \\
\text { Antioxidant }(0.973) \\
\text { Erythropoiesis stimulant }(0.823) \\
\text { Biliary tract disorders treatment }(0.808) \\
\text { Laxative }(0.709)\end{array}$ & Activity not studied & \\
\hline 121 & $\begin{array}{c}\text { Hypolipemic }(0.995) \\
\text { Atherosclerosis treatment }(0.989) \\
\text { Lipoprotein disorders treatment }(0.980) \\
\text { Antioxidant }(0.970) \\
\text { Biliary tract disorders treatment }(0.808) \\
\text { Erythropoiesis stimulant }(0.730) \\
\text { Laxative }(0.683)\end{array}$ & Activity not studied & \\
\hline 122 & $\begin{array}{c}\text { Hypolipemic }(0.996) \\
\text { Atherosclerosis treatment }(0.995) \\
\text { Lipoprotein disorders treatment }(0.991) \\
\text { Antioxidant }(0.978) \\
\text { Erythropoiesis stimulant }(0.756)\end{array}$ & Activity not studied & \\
\hline 123 & $\begin{array}{l}\text { Hypolipemic }(0.913) \\
\text { Antihypercholesterolemic }(0.884) \\
\text { Atherosclerosis treatment }(0.822)\end{array}$ & Activity not studied & \\
\hline 124 & $\begin{array}{l}\text { Antihypercholesterolemic }(0.902) \\
\text { Hypolipemic }(0.899) \\
\text { Atherosclerosis treatment }(0.791)\end{array}$ & Activity not studied & \\
\hline 125 & Antihypercholesterolemic (0.905) & Activity not studied & \\
\hline 126 & $\begin{array}{c}\text { Antihypercholesterolemic }(0.908) \\
\text { Bone diseases treatment }(0.772) \\
\text { Hypolipemic }(0.769)\end{array}$ & Activity not studied & \\
\hline 127 & $\begin{array}{c}\text { Antihypercholesterolemic }(0.912) \\
\text { Antineoplastic }(0.884) \\
\text { Anticarcinogenic }(0.753)\end{array}$ & $\begin{array}{l}\text { Cytotoxic activity } \\
\text { Agent for } \\
\text { Alzheimer's } \\
\text { disease }\end{array}$ & {$[303,310]$} \\
\hline 128 & $\begin{array}{c}\text { Antihypercholesterolemic (0.953) } \\
\text { Antineoplastic }(0.856) \\
\text { Anticarcinogenic }(0.804)\end{array}$ & $\begin{array}{l}\text { Cytotoxic activity } \\
\text { Agent for } \\
\text { Alzheimer's } \\
\text { disease }\end{array}$ & {$[303,310]$} \\
\hline
\end{tabular}

${ }^{*}$ Only activities with $\mathrm{Pa}>0.5$ are shown. 


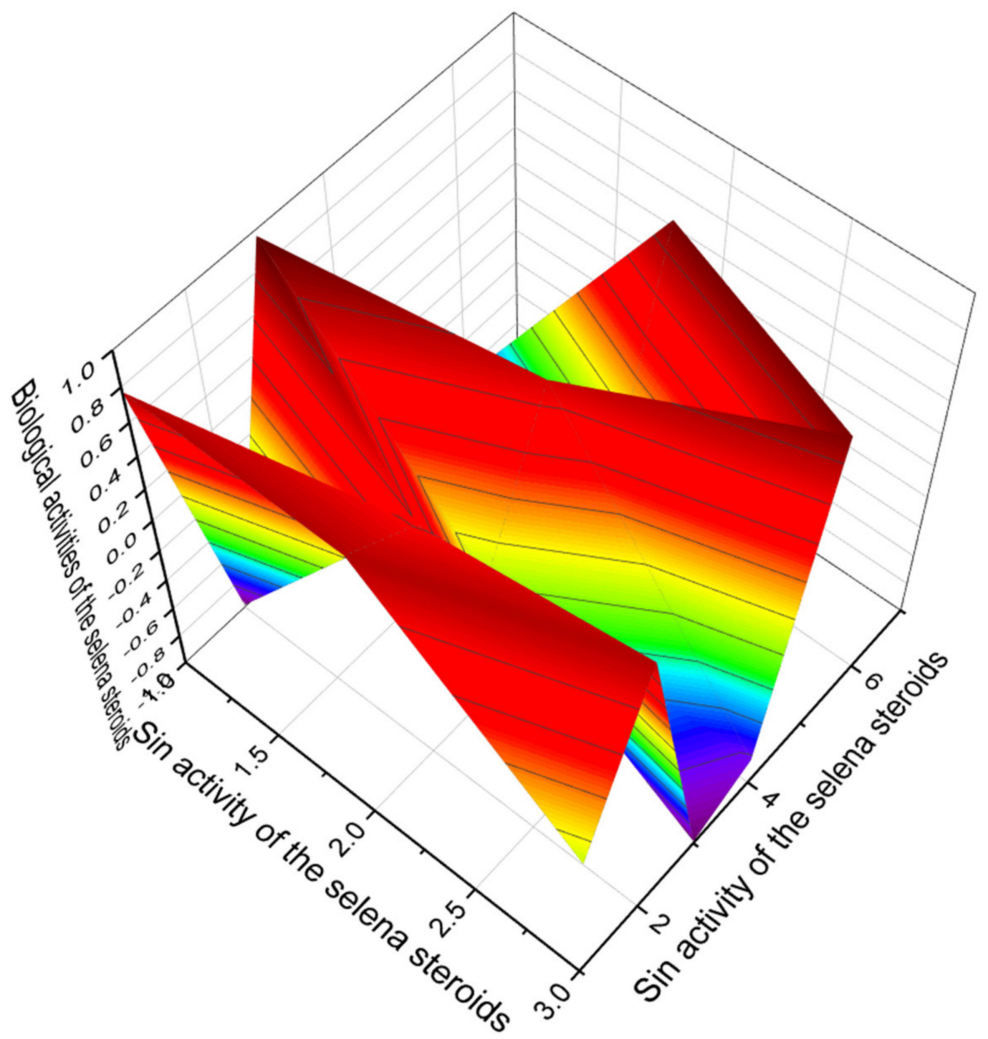

Figure 26. The 3D graph shows the predicted and calculated biological activity of the selena steroids (compound numbers: 120, 121 and 122) showing the highest degree of confidence, more than $99.5 \%$.

\subsection{Bioactive Tellura Steroids}

Tellura steroids are a rare group of organic synthetic compounds whose biological activity is of great interest for medicine, pharmacology, and the pharmaceutical industry $[304,306,308,309,311]$. The chemical structures of steroids and triterpenoids are shown in Figure 27, and the biological activity is shown in Table 12.

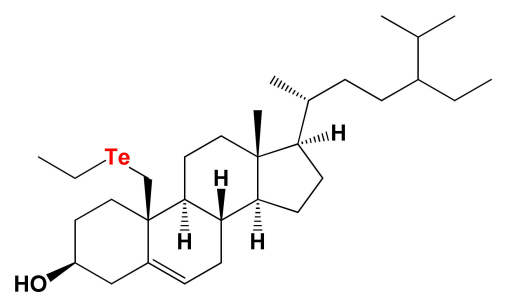

129

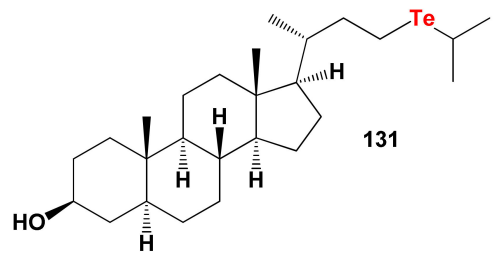

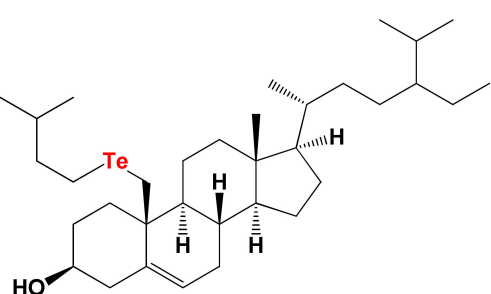

130<smiles>CC(C)[Ge](=O)CC[C@@H](C)[C@H]1CC[C@H]2[C@@H]3CC[C@H]4C[C@@H](O)CC[C@]4(C)[C@H]3CC[C@@]21C</smiles>

Figure 27. Bioactive synthetic tellura steroids. 
Table 12. Biological activities of tellura steroids.

\begin{tabular}{|c|c|c|}
\hline No. & Discovered Activity, $(\mathrm{Pa})$ * & Reported Activity \\
\hline 129 & $\begin{array}{c}\text { Atherosclerosis treatment }(0.977) \\
\text { Antioxidant }(0.963) \\
\text { Antihypercholesterolemic }(0.956) \\
\text { Antiparkinsonian }(0.955) \\
\text { Neurodegenerative diseases } \\
\text { treatment }(0.954) \\
\text { Alzheimer's disease treatment } \\
(0.940) \\
\text { Antihyperlipoproteinemic }(0.811)\end{array}$ & Activity not studied \\
\hline 130 & $\begin{array}{c}\text { Antihypercholesterolemic }(0.958) \\
\text { Atherosclerosis treatment }(0.890) \\
\text { Alzheimer's disease treatment } \\
(0.838) \\
\text { Antioxidant }(0.807) \\
\text { Neurodegenerative diseases } \\
\text { treatment }(0.801)\end{array}$ & Activity not studied \\
\hline 131 & $\begin{array}{c}\text { Antioxidant }(0.922) \\
\text { Atherosclerosis treatment }(0.908) \\
\text { Neurodegenerative diseases } \\
\text { treatment }(0.877) \\
\text { Antihypercholesterolemic }(0.869) \\
\text { Alzheimer's disease treatment } \\
(0.868) \\
\text { Antiparkinsonian }(0.848)\end{array}$ & Activity not studied \\
\hline 132 & $\begin{array}{c}\text { Antihypercholesterolemic }(0.909) \\
\text { Atherosclerosis treatment }(0.876) \\
\text { Alzheimer's disease treatment } \\
(0.828) \\
\text { Neurodegenerative diseases } \\
\text { treatment }(0.808) \\
\text { Biliary tract disorders treatment } \\
(0.807)\end{array}$ & Activity not studied \\
\hline
\end{tabular}

₹ Only activities with $\mathrm{Pa}>0.5$ are shown.

We found only four tellura steroids, which exhibit properties as regulators of lipid metabolism, dominated by antihypercholesterolemic activity. However, the most interesting from the point of view of pharmacological values is tellura steroid with number 129. In addition to its antihypercholesterolemic activity, it is worth pointing out that this steroid has also been shown to be used as an agent for the treatment of neurodegenerative diseases Alzheimer's and Parkinson's with strong confidence, over 94 percent. The 3D graph demonstrating the predicted and calculated biological activity of the tellura steroid (129) is shown in Figure 28. 


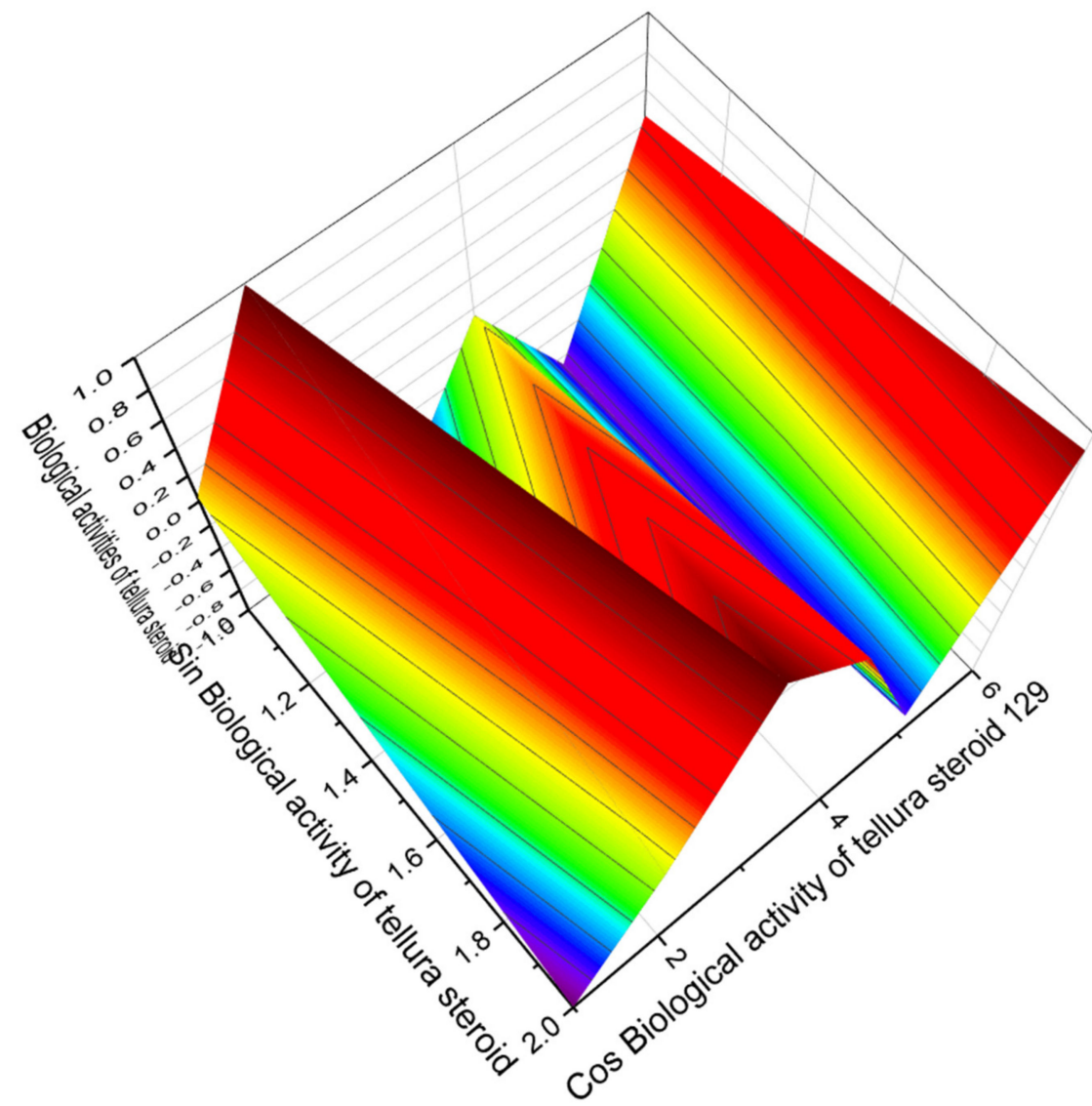

Figure 28. The 3D graph shows the predicted and calculated biological activity of the tellura steroid (129) showing the highest degree of confidence, more than $99.5 \%$. This tellura steroid is interesting, in that it is a rare case when any chemical compound shows simultaneously such activities as prevention and treatment of neurodegenerative diseases Alzheimer's and Parkinson's with strong confidence, over 94 percent. In addition, this steroid demonstrated antioxidant and antihypercholesterolemic activities, and can also be used as a potential drug for the treatment of atherosclerosis. The maximum values of various biological activities are shown in red.

\subsection{Bioactive Astatosteroids}

Astatine is natural radioelement that has short-lived isotopes, and synthetic organic astatine compounds are commonly used for radiotherapy [312-314]. Steroids containing astatine, which are called astatosteroids, were first synthesized approximately 40 years ago [315]. Some astatosteroids (2- and 4-astatoestradiol and 6-At-cholesterol, 135, 136, and 137) have been synthesized in high radiochemical yields by the reaction of ${ }^{211} \mathrm{At} / \mathrm{I}_{2}$ and the corresponding chloromercury compounds. The stability in vitro was determined under different conditions in comparison with the analogous iodo compounds [313]. More recently, 6-astatomethyl-19-norcholest-5(10)-en-3 $\beta$-ol (134) was synthesized at a yield of $60-70 \%$ [316]. The biological activity of these compounds has not been determined. The predicted biological activity of astatosteroids is presented in Table 13. The most characteristic biological properties for these steroids were antineoplastic, antiseborrheic, antisecretoric, and antihypercholesterolemic activities. The chemical structures of steroids are shown in Figure 29 and the biological activity is shown in Table 13. For all astatosteroids shown in Figure 29, antihypercholesterolemic activity is dominated. In addition, all steroids of this group, as shown by PASS, have properties as a treatment for bone diseases. This is a rare property for steroids. Figure 30 shows the 3D graph the predicted and calculated biological activity of the astatosteroid (133). 
Table 13. Biological activities of astatosteroids.

\begin{tabular}{|c|c|c|}
\hline No. & Discovered Activity, $(\mathrm{Pa}) *$ & Reported Activity \\
\hline 133 & $\begin{array}{c}\text { Antihypercholesterolemic }(0.967) \\
\text { Antineoplastic }(0.824) \\
\text { Bone diseases treatment }(0.796) \\
\text { Hypolipemic }(0.785) \\
\text { Neuroprotector }(0.758) \\
\text { Antipsoriatic }(0.739) \\
\text { Anti-inflammatory }(0.728) \\
\text { Apoptosis agonist }(0.724) \\
\text { Prostate disorders treatment }(0.719)\end{array}$ & Activity not studied \\
\hline 134 & $\begin{array}{c}\text { Antihypercholesterolemic }(0.927) \\
\text { Bone diseases treatment }(0.784) \\
\text { Hypolipemic }(0.740)\end{array}$ & Activity not studied \\
\hline 135 & $\begin{array}{l}\text { Antihypercholesterolemic }(0.920) \\
\text { Growth stimulant }(0.805) \\
\text { Bone diseases treatment }(0.743)\end{array}$ & Activity not studied \\
\hline 136 & $\begin{array}{l}\text { Antihypercholesterolemic }(0.901) \\
\text { Bone diseases treatment }(0.720) \\
\text { Growth stimulant }(0.703)\end{array}$ & Activity not studied \\
\hline 137 & $\begin{array}{l}\text { Antihypercholesterolemic }(0.912) \\
\text { Bone diseases treatment }(0.777)\end{array}$ & Activity not studied \\
\hline
\end{tabular}

* Only activities with $\mathrm{Pa}>0.5$ are shown.

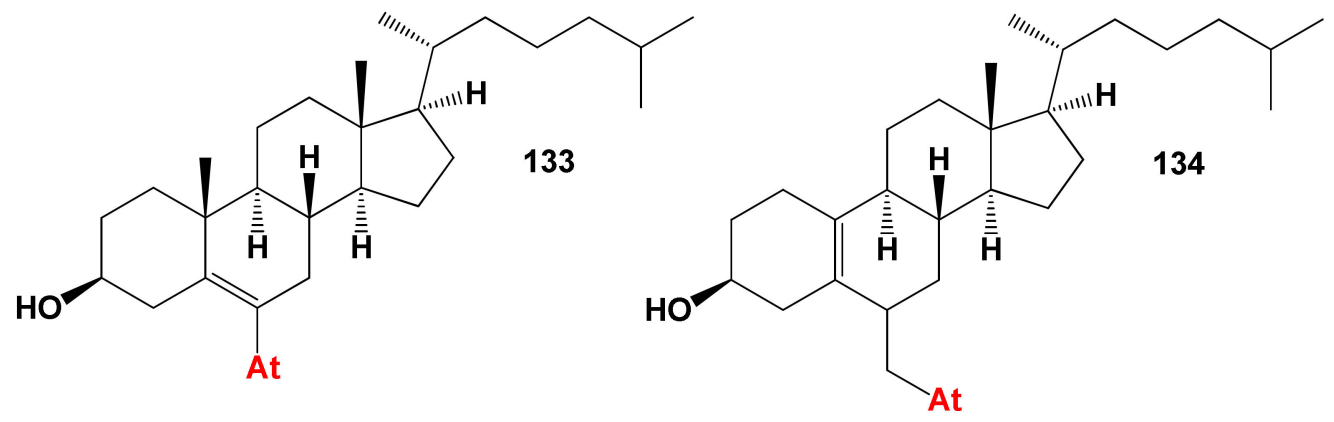<smiles>CCc1cc2c(cc1O)CC[C@@H]1[C@@H]2CC[C@]2(C)[C@@H](O)CC[C@@H]12</smiles><smiles>CCc1c(O)ccc2c1CC[C@@H]1[C@@H]2CC[C@@]2(C)[C@H]1CC[C@H]2O</smiles>

135<smiles>CCc1cc2c(c(I)c1O)CC[C@@H]1[C@@H]2CC[C@@]2(C)[C@@H](O)CC[C@@H]12</smiles>

Figure 29. Biological active synthetic astatosteroids. 


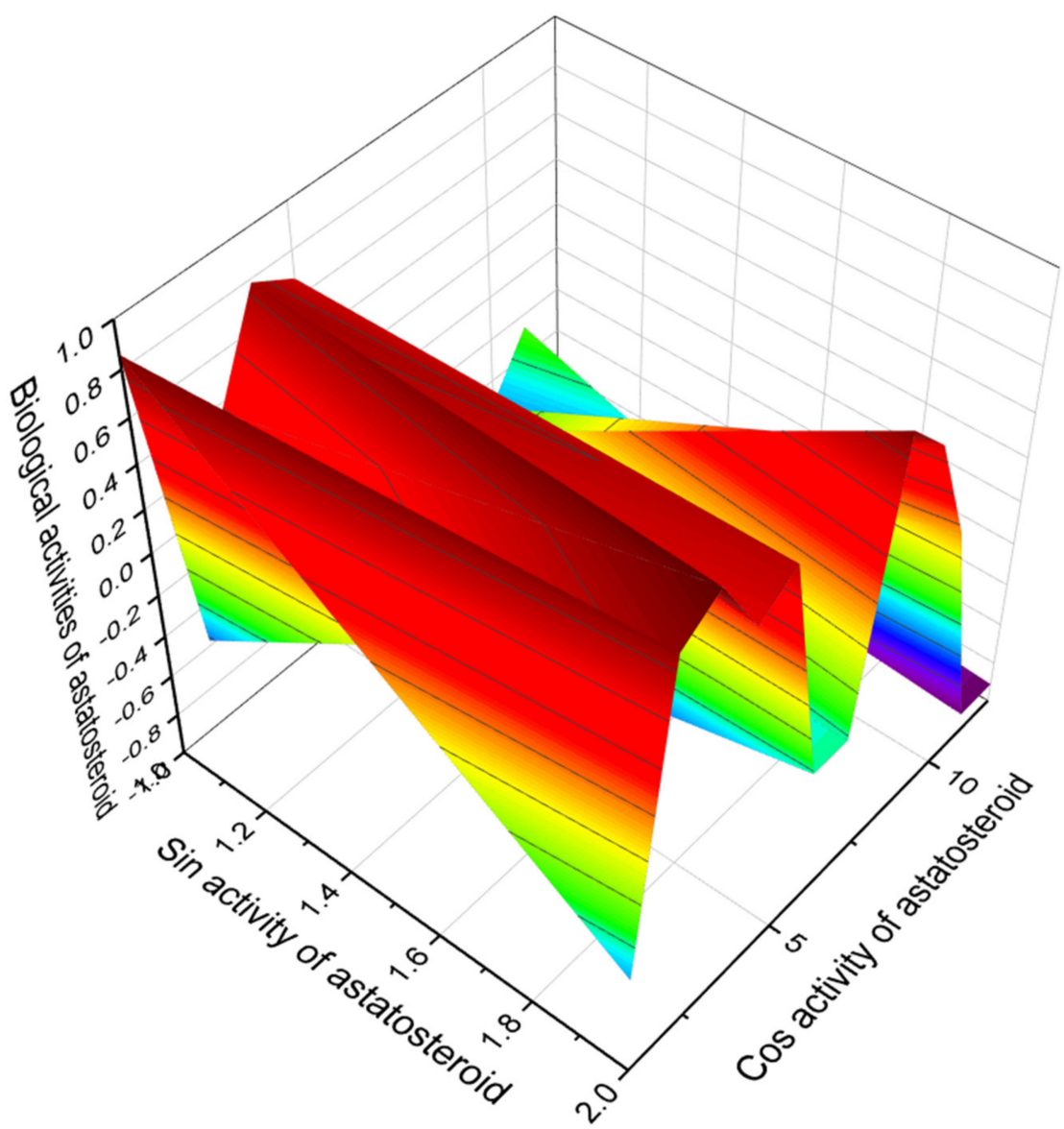

Figure 30. The 3D graph shows the predicted and calculated biological activity of the astatosteroid (133) showing the highest degree of confidence, more than $97.6 \%$. Moreover, it can also be used as a potential drug for the treatment of bone diseases.

\section{Conclusions}

This review focuses on the intriguing topic of lipid metabolism regulation. The literature does not fully describe the means that regulate lipid metabolism. Steroids and triterpenoids presented in this review are of great interest for medicine, and some of them may be potential regulators of lipid metabolism. However, experimental work is required to confirm this thesis. In the world in general, and in North America in particular, the study of biological activities using computer programs is gaining popularity. This is due to the fact that the number of isolated natural and synthetic compounds has long exceeded 20 million; there is no technical possibility of determining biological activity experimentally. Using the PASS program for the last fifteen years has shown that we are on the right track. During this time, we have investigated over 10,000 compounds and identified their potential biological activities. Based on early studies, we have selected a group of steroids and triterpenoids that are presented in this review and correspond to the name of the topic, as potential regulators of lipid metabolism.

Funding: This work did not receive any specific grant from funding agencies in the public, commercial, or not-for-profit sectors.

Acknowledgments: The author is grateful to Anne Kathrin Bendt (Life Sciences Institute, National University of Singapore, Singapore) who initiated this review, and grateful to Tatyana A. Gloriozova (Institute of Biomedical Chemistry, Moscow, Russia) for prompt help in determining the biological activity of the steroids and triterpenoids presented in the article.

Conflicts of Interest: The author declares that he has no known competing financial interests or personal relationships that could affect the work described in this article. 


\section{References}

1. Cheng, X.; Smith, J.C. Biological membrane organization and cellular signaling. Chem. Rev. 2019, 119, 5849-5880. [CrossRef]

2. Jensen, M.Ø.; Mouritsen, O.G. Lipids do influence protein function-The hydrophobic matching hypothesis revisited. Biochim. Biophys. Acta Biomembr. 2004, 1666, 205-226. [CrossRef] [PubMed]

3. MacCallum, J.L.; Tieleman, D.P. Hydrophobicity scales: A thermodynamic looking glass into lipid-protein interactions. Trends Biochem. Sci. 2011, 36, 653-662. [CrossRef] [PubMed]

4. Lundstedt, E.; Kahne, D.; Ruiz, N. Assembly, and maintenance of lipids at the bacterial outer membrane. Chem. Rev. 2021, 121, 5098-5123. [CrossRef] [PubMed]

5. Suzumura, M. Phospholipids in marine environments: A review. Talanta 2005, 66, 422-434. [CrossRef]

6. Li, J.; Wang, X.; Zhang, T.; Wang, C.; Huang, Z.; Luo, X.; Deng, Y. A review on phospholipids and their main applications in drug delivery systems. Asian J. Pharm. Sci. 2015, 10, 81-98. [CrossRef]

7. Dowhan, W. Molecular basis for membrane phospholipid diversity: Why are there so many lipids? Ann. Rev. Biochem. 1997, 66, 199-232. [CrossRef] [PubMed]

8. Berne, B.J.; Weeks, J.D.; Zhou, R. Dewetting and hydrophobic interaction in physical and biological systems. Ann. Rev. Phys. Chem. 2009, 60, 85-103. [CrossRef]

9. Gisterå, A.; Hansson, G. The immunology of atherosclerosis. Nat. Rev. Nephrol. 2017, 13, 368-380. [CrossRef]

10. Alexopoulos, N.; Raggi, P. Calcification in atherosclerosis. Nat. Rev. Cardiol. 2009, 6, 681-688. [CrossRef]

11. Faulds, M.H.; Zhao, C.; Dahlman-Wright, K.; Gustafsson, J.Å. The diversity of sex steroid action: Regulation of metabolism by estrogen signaling. J. Endocrinol. 2011, 212, 3-12. [CrossRef]

12. Dembitsky, V.M. Antitumor and hepatoprotective activity of natural and synthetic neo steroids. Prog. Lipid Res. 2020, 79, 101048. [CrossRef]

13. Dembitsky, V.M.; Gloriozova, T.A.; Poroikov, V.V. Antitumor profile of carbon-bridged steroids (CBS) and triterpenoids. Mar. Drugs 2021, 19, 324. [CrossRef]

14. Pounina, T.A.; Gloriozova, T.A.; Savidov, N.; Dembitsky, V.M. Sulfated and sulfur-containing steroids and their pharmacological profile. Mar. Drugs 2021, 19, 240. [CrossRef]

15. Zagoskin, P.P.; Erlykina, E.I. Bile acids as a new type of steroid hormones regulating nonspecific energy expenditure of the body (review). Sovremen. Tehnol. Med. 2020, 12, 114. [CrossRef]

16. Ko, C.W.; Qu, J.; Black, D.D.; Tso, P. Regulation of intestinal lipid metabolism: Current concepts and relevance to disease. Nat. Rev. Gastroenterol. Hepatol. 2020, 17, 169-183. [CrossRef]

17. De Bose-Boyd, R.A. Significance, and regulation of lipid metabolism. Semin. Cell Dev. Biol. 2018, 81, 97. [CrossRef]

18. Luo, J.; Yang, H.; Song, B.L. Mechanisms, and regulation of cholesterol homeostasis. Nat. Rev. Mol. Cell Biol. 2020, 21, 225-245. [CrossRef]

19. Schoeler, M.; Caesar, R. Dietary lipids, gut microbiota, and lipid metabolism. Rev. Endocr. Metab. Disord. 2019, $20,461-472$. [CrossRef]

20. Matsushita, Y.; Nakagawa, H.; Koike, K. Lipid metabolism in oncology: Why it matters, how to research, and How to treat. Cancers 2021, 13, 474. [CrossRef]

21. Edgar, A.; Doisy, E.A. An ovarian hormone: Preliminary report on its localization, extraction and partial purification, and action in test animals. J. Am. Med. Assoc. 1923, 81, 819-821.

22. Doisy, E.A.; Clement, D.V.; Sidney, T. Folliculin from urine of pregnant women. Am. J. Phys. 1929, 90, 329-330.

23. Butenandt, A.B. Über, Progynonein krystallisiertes weibliches Sexualhormon. Die Naturwissenschaften 1929, 17, 879. [CrossRef]

24. Butenandt, A. Über physikalische und chemische Eigenschaften des krystallisierten Follikelhormons. Untersuchungen über das weibliche Sexualhormon. Hoppe-Seyler's Zeit. Physiol. Chem. 1930, 191, 140-156. [CrossRef]

25. Butenandt, A. Über die chemische Untersuchung der Sexualhormone. Zeit Angew. Chem. 1931, 44, 905-908. [CrossRef]

26. Butenandt, A.; Jacobi, H. Über die Darstellung eines krystallisierten pflanzlichen Tokokinins (Thelykinins) und seine Identifizierung mit dem $\alpha$-Follikelhormon. Untersuchungen über das weibliche Sexualhormon. Hoppe Seyler's Z. Physiol. Chem. 1933, 218, 104-112. [CrossRef]

27. Ramirez, M.P.; Haas, S. Hormone replacement therapy for women: The benefits, risks, and considerations for use in 2003. Curr Opinion Endocrin. Diabet. 2003, 10, 400-418. [CrossRef]

28. Fluhmann, C.F. Estrogenic hormones: Their clinical usage. Cal. West Med. 1938, 49, 362-366.

29. Younglai, E.V.; Solomon, S. Formation of estra-1,3,5(10)-triene-3,15a,16a,17b-tetrol (estetrol) and estra-1,3,5(10)-triene-3,15a,17btriol from neutral precursors. J. Clin. Endocrinol. Metab. 1968, 28, 1611-1617. [CrossRef]

30. Raeside, J.I. A brief account of the discovery of the fetal/placental unit for estrogen production in equine and human pregnancies: Relation to human medicine. Yale J. Biol. Med. 2017, 90, 449-461.

31. Trifunović, J.; Borčić, V.; Vukmirović, S.; Mikov, M. Structural insights into anticancer activity of D-ring modified estrone derivatives using their lipophilicity in estimation of SAR and molecular docking studies. Drug Test Anal. 2017, 9, 1650. [CrossRef]

32. Dohrn, M.; Faure, W.; Poll, H.; Blotevogel, W. Tokokinine, Stoff mit sexualhormonartiger Wirkung aus Pflanzenzellen. Med. Klin. 1926, 22, 1417-1419.

33. Skarzynski, B. An oestrogenic substance from plant material. Nature 1933, 131, 766.

34. Janeczko, A.; Skoczowski, A. Mammalian sex hormones in plants. Folia Histochem. Cytobiol. 2005, 43, 71-79. 
35. Jailer, J.W. The metabolism of the estrogens: A review. J. Clin. Endocrinol. 1949, 9, 557-572. [CrossRef]

36. Xu, Y.; López, M. Central regulation of energy metabolism by estrogens. Mol. Metabol. 2018, 15, 104-115. [CrossRef]

37. Ventura-Clapier, R.; Piquereau, J.; Veksler, V.; Garnier, A. Estrogens, estrogen receptors effects on cardiac and skeletal muscle mitochondria. Front. Endocrinol. 2019, 10, 557. [CrossRef]

38. Le, J.; Thomas, N.; Gurvich, C. Cognition, the menstrual cycle, and premenstrual disorders: A Review. Brain Sci. 2020, 10, 198. [CrossRef]

39. Su, Z.; Yuan, W.; Wang, P.; Li, S. Ethnobotany, phytochemistry, and biological activities of Taxodium Rich. Pharm. Crops 2013, 4, 1-14.

40. Sukandar, E.Y.; Suganda, A.G.; Pertiwi, G.U. Aktivitas sediaan yang mengandung ekstrak daun ketapang pada kulit kelinci yang diinfeksi dengan ephidermophyton floccosum dan Candida albicans. Acta Pharm. Ind. 2007, 32, 45-49.

41. Suganda, A.G.; Sukandar, E.Y.; Hardhiko, R.S. Aktivitas antimikroba ekstrak etanol daun yang dipetik dan ekstrak air daun gugur pohon ketapang (Terminalia catappa L.). Acta Pharm. Ind. 2004, 29, 129-133.

42. Suganda, A.G.; Sukandar, E.Y.; Ratna, L. Aktivitas antimikroba ekstrak etanol daun dua belas jenis Tumbuhan marga terminalia (Combretaceae). Acta Pharm. Ind. 2006, 31, 18-23.

43. Pranjali, C.; Lokesh, R. A review on medicinal potential of Terminalia catappa. Int. J. Green Pharm. 2020, 14, 229-234.

44. Misico, R.I.; Veleiro, A.S.; Burton, G.; Oberti, J.C. Withanolides from Jaborosa leucotricha. Phytochemistry 1997, 45, 1045-1048. [CrossRef]

45. Yan, X.-H.; Liu, H.-L.; Huang, H.; Li, X.-B.; Guo, Y.-W. Steroids with aromatic A rings from the Hainan soft coral Dendronephthya studeri Ridley. J. Nat. Prod. 2011, 74, 175-180. [CrossRef]

46. Lu, Z.; Van Wagoner, R.M.; Harper, M.K.; Hooper, J.N.A.; Ireland, C.M. Two ring-A aromatized bile acids from the marine sponge Sollasella moretonensis. Nat. Prod. Commun. 2010, 5, 1571-1574. [CrossRef]

47. Yeung, B.K.S.; Hamann, M.T.; Scheuer, P.J.; Kelly-Borges, M. Hapaioside: A 19-norpregnane glycoside from the sponge Cribrochalina olemda. Tetrahedron 1994, 50, 12593-12598. [CrossRef]

48. Nakao, Y.; Kuo, J.; Yoshida, W.Y.; Kelly, M.; Scheuer, P.J. More kapakahines from the marine sponge Cribrochalina olemda. Org. Lett. 2003, 5, 1387-1390. [CrossRef]

49. Tomono, Y.; Hirota, H.; Imahara, Y.; Fusetani, N. Four new steroids from two octocorals. J. Nat. Prod. 1999, 62, $1538-1541$. [CrossRef] [PubMed]

50. Barrero, A.F.; Oltra, J.E.; Poyatos, J.A.; Jiménez, D.; Oliver, E. Phycomysterols and other sterols from the fungus Phycomyces blakesleeanus. J. Nat. Prod. 1998, 61, 1491-1496. [CrossRef]

51. Liu, X.H.; Tang, X.Z.; Miao, F.P.; Ji, N.Y. A new pyrrolidine derivative and steroids from an algicolous Gibberella zeae strain. Nat. Prod. Commun. 2011, 6, 1243-1246. [CrossRef] [PubMed]

52. Luo, X.; Li, F.; Shinde, P.B.; Hong, J.; Lee, C.-O.; Im, K.S.; Jung, J.H. 26,27-Cyclosterols and other polyoxygenated sterols from marine sponge Topsentia sp. J. Nat. Prod. 2006, 69, 1760-1768. [CrossRef] [PubMed]

53. Brown, A.C.; Fraser, T.R. The connection of chemical constitution and physiological action. Trans. Roy. Soc. Edinb. 1868, 25, 224-242.

54. Cros, A.F.A. Action de L'alcohol Amylique Sur L'organisme. Ph.D. Thesis, University of Strasbourg, Strasbourg, France, 1863.

55. Richet, M.C. Note sur le rapport entre la toxicité et les propriétes physiques des corps. Compt. Rend. Soc. Biol. 1893, 45, 775-776.

56. Meyer, H. Zur Theorie der AIkoholnarkose. Arch. Exp. Path. Pharm. 1899, 42, 109-118. [CrossRef]

57. Overton, C.E. Studien über Die Narkose; Fischer: Jena, Germany, 1901.

58. Hammett, L.P. Some relations between reaction rates and equilibrium constants. Chem. Rev. 1935, 17, 125-136. [CrossRef]

59. Hammett, L.P. The effect of structure upon the reactions of organic compounds. Benzene derivatives. J. Am. Chem. Soc. 1937, 59, 96-103. [CrossRef]

60. Taft, R.W. Separation of polar, steric and resonance effects in reactivity. In Steric Effects in Organic Chemistry; Newman, M.S., Ed.; Wiley: Hoboken, NJ, USA, 1956; pp. 556-675.

61. Hansch, C.; Fujita, T. $\pi-\tau-\pi$ Analysis. A method for the correlation of biological activity and chemical structure. J. Am. Chem. Soc. 1964, 86, 1616-1626. [CrossRef]

62. Hansch, C.; Leo, A. Exploring QSAR; American Chemical Society: Washington, DC, USA, 1995.

63. Sliwoski, G.; Kothiwale, S.; Meiler, J.; Lowe, E.W., Jr. Computational methods in drug discovery. Pharm. Rev. 2014, 66, 334-395. [CrossRef]

64. Leelananda, S.P.; Lindert, S. Computational methods in drug discovery. Beilstein J. Org. Chem. 2016, 12, 2694-2718. [CrossRef]

65. Kokh, D.B.; Amaral, M.; Bomke, J.; Grädler, U.; Musil, D. Estimation of drug-target residence times by $\tau$-random acceleration molecular dynamics simulations. J. Chem. Theor. Comput. 2018, 14, 3859-3869. [CrossRef]

66. Cherkasov, A.M.; Muratov, E.N.; Fourches, D.; Varnek, A.; Baskin, I.I. QSAR modeling: Where have you been? Where are you going to? J. Med. Chem. 2014, 57, 4977-5010. [CrossRef]

67. Burov, Y.V.; Poroikov, V.V.; Korolchenko, L.V. National system for registration and biological testing of chemical compounds: Facilities for new drugs search. Bull. Natl. Cent. Biol. Act. Comp. 1990, 1, 4-25.

68. Muratov, E.N.; Bajorath, J.; Sheridan, R.P.; Tetko, I.; Filimonov, D.; Poroikov, V.; Oprea, T. QSAR without borders. Chem. Soc. Rev. 2020, 49, 3525-3564. [CrossRef] 
69. Poroikov, V.V.; Filimonov, D.A.; Gloriozova, T.A.; Lagunin, A.A.; Druzhilovskiy, D.S.; Rudik, A.V. Computer-aided prediction of biological activity spectra for organic compounds: The possibilities and limitations. Russ. Chem. Bull. 2019, 68, $2143-2154$. [CrossRef]

70. Filimonov, D.A.; Druzhilovskiy, D.S.; Lagunin, A.A.; Gloriozova, T.A.; Rudik, A.V.; Dmitriev, P.V.; Poroikov, V.V. Computer-aided prediction of biological activity spectra for chemical compounds: Opportunities and limitations. Biom. Chem. Res. Method. 2018, 1, e00004. [CrossRef]

71. Anusevicius, K.; Mickevicius, V.; Stasevych, M.; Zvarych, V.; Komarovska-Porokhnyavets, O.; Novikov, V.; Tarasova, O.; Gloriozova, T.; Poroikov, V. Design, synthesis, in vitro antimicrobial activity evaluation and computational studies of new N-(4-iodophenyl)-Alanine derivatives. Res. Chem. Intermed. 2015, 41, 7517-7540. [CrossRef]

72. Murtazalieva, K.A.; Druzhilovskiy, D.S.; Goel, R.K.; Sastry, G.N.; Poroikov, V.V. How good are publicly available web services that predict bioactivity profiles for drug repurposing? SAR QSAR Environ. Res. 2017, 28, 843-862. [CrossRef]

73. PASS Online. Available online: http:/ / www.way2drug.com/passonline/ (accessed on 4 June 2021).

74. Lagunin, A.A.; Goel, R.K.; Gawande, D.Y.; Priynka, P.; Gloriozova, T.A.; Dmitriev, A.V.; Ivanov, S.M.; Rudik, A.V.; Konova, V.I.; Pogodin, P.V. Chemo- and bioinformatics resources for in silico drug discovery from medicinal plants beyond their traditional use: A critical review. Nat. Prod. Rep. 2014, 31, 1585-1611. [CrossRef]

75. Goel, R.K.; Poroikov, V.; Gawande, D.; Lagunin, A.; Randhawa, P.; Mishra, A. Revealing medicinal plants useful for comprehensive management of epilepsy and associated co-morbidities through in silico mining of their phytochemical diversity. Planta Med. 2015, 81, 495-506.

76. Dembitsky, V.M.; Gloriozova, T.A.; Poroikov, V.V. Naturally occurring plant isoquinoline N-oxide alkaloids: Their pharmacological and SAR activities. Phytomedicine 2015, 22, 183-202. [CrossRef] [PubMed]

77. Gawande, D.Y.; Druzhilovsky, D.; Gupta, R.C.; Poroikov, V.; Goel, R.K. Anticonvulsant activity and acute neurotoxic profile of Achyranthes aspera Linn. J. Ethnopharmacol. 2017, 202, 97-102. [CrossRef] [PubMed]

78. Dembitsky, V.M.; Dzhemileva, L.; Gloriozova, T.; D'yakonov, V. Natural and synthetic drugs used for the treatment of the dementia. Biochem. Biophys. Res. Commun. 2020, 524, 772-783. [CrossRef] [PubMed]

79. Lagunin, A.; Povydysh, M.; Ivkin, D.; Luzhanin, V.; Krasnova, M. Antihypoxic action of Panax japonicus, Tribulus terrestris and Dioscorea deltoidea cell cultures: In silico and animal studies. Mol. Inform. 2020, 39, 2000093. [CrossRef]

80. Dembitsky, V.M.; Ermolenko, E.; Savidov, N.; Gloriozova, T.A.; Poroikov, V.V. Antiprotozoal and antitumor activity of natural polycyclic endoperoxides: Origin, structures, and biological activity. Molecules 2021, 19, 686. [CrossRef]

81. Qureshi, R.; Picon-Ruiz, M.; Aurrekoetxea-Rodriguez, I.; Kesmodel, S.; del Mar Vivanco, M.; Slinger, J.M. The major pre- and postmenopausal estrogens play opposing roles in obesity-driven mammary inflammation and breast cancer development. Cell Metab. 2020, 31, 1154-1172. [CrossRef]

82. Ahmed, S.; Owen, C.P.; James, K.; Sampson, L.; Patel, C.K. Review of estrone sulfatase and its inhibitors-An important new target against hormone dependent breast cancer. Curr. Med. Chem. 2002, 9, 263-273. [CrossRef]

83. Neilson, H.K.; Friedenreich, C.M.; Brockton, N.T.; Millikan, R.C. Physical activity and postmenopausal breast cancer: Proposed biologic mechanisms and areas for future research. Cancer Epidemiol. Biomark. Prev. 2009, 18, 11-27. [CrossRef]

84. Bassol, S.; Garza-Flores, J. Review of ovulation return upon discontinuation of once-a-month injectable contraceptives. Contraception 1994, 49, 441-453. [CrossRef]

85. McCarthy, M.M. Estradiol, and the developing brain. Physiol. Rev. 2008, 88, 91-134. [CrossRef]

86. Soltysik, K.; Czekaj, P. Membrane estrogen receptors-Is it an alternative way of estrogen action? J. Physiol. Pharmacol. 2013, 64, 129-142.

87. Mauvais-Jarvis, F.; Klein, S.L.; Levin, E.R. Estradiol, progesterone, immunomodulation, and COVID-19 outcomes. Endocrinology 2020, 161, 127. [CrossRef]

88. Lappano, R.; Rosano, C.; De Marco, P.; De Francesco, E.M.; Pezzi, V.; Maggiolini, M. Estriol acts as a GPR30 antagonist in estrogen receptor-negative breast cancer cells. Mol. Cell. Endocrinol. 2010, 320, 162-170. [CrossRef]

89. Ali, E.S.; Mangold, C.; Peiris, A.N. Estriol: Emerging clinical benefits. Menopause 2017, 24, 1081-1085. [CrossRef]

90. Li, M.; Scott, R.Y. A review on structural elucidation of metabolites of environmental steroid hormones via liquid chromatographymass spectrometry. Trends Anal. Chem. 2018, 109, 142-153.

91. Brandán, S.A. Structural and vibrational studies of equilenin, equilin and estrone steroids. Biointerface Res. Appl. Chem. 2019, 9, $4502-4516$.

92. Bhavnani, B.R.; Stanczyk, F.Z. Pharmacology of conjugated equine estrogens: Efficacy, safety and mechanism of action. J. Steroid Biochem. Mol. Biol. 2014, 142, 16-29. [CrossRef]

93. Ruder, H.J.; Loriaux, L.; Lipsett, M.B. Lipsett, Estrone sulfate: Production rate and metabolism in man. J. Clin. Investig. 1972, 51, 1020-1033. [CrossRef]

94. Banjare, L.; Jain, A.K.; Thareja, A. Dual aromatase-sulphatase inhibitors (DASIs) for the treatment of hormone dependent breast cancer. Mini Rev. Med. Chem. 2021, 21, 10. [CrossRef]

95. Blackwell, L.F.; Cooke, D.G.; Brown, S. The use of estrone-3-glucuronide and pregnanediol-3-glucuronide excretion rates to navigate the continuum of ovarian activity. Front. Public Health 2018, 6, 153. [CrossRef]

96. Katayama, S.; Fishman, J. 2-Hydroxyestrone suppresses and 2-methoxyestrone augments the preovulatory prolactin surge in the cycling rat. Endocrinology 1982, 110, 1448-1450. [CrossRef] 
97. Gupta, M.; McDougal, A.; Safe, S. Estrogenic and antiestrogenic activities of $16 \alpha$ - and 2-hydroxy metabolites of $17 \beta$-estradiol in MCF-7 and T47D human breast cancer cells. J. Steroid Biochem. Mol. Biol. 1998, 67, 413-419. [CrossRef]

98. Bradlow, H.L.; Telang, N.T.; Sepkovic, D.W.; Osborne, M.P. 2-Hydroxyestrone: The good estrogen. J. Endocrinol. 1996, 150, S259-S265.

99. Williams, J.G.; Longcope, C.; Williams, K.I.H. 4-Hydroxyestrone: A new metabolite of estradiol-17 $\beta$ from humans. Steroids 1974, 24, 687-701. [CrossRef]

100. Emons, G.; Hoppen, H.O.; Ball, P.; Knuppen, R. 4-Hydroxyestrone, isolation and identification in human urine. Steroids 1980, 36, 73-79. [CrossRef]

101. Choi, H.J.; Lee, A.J.; Kang, K.S. 4-Hydroxyestrone, an endogenous estrogen metabolite. Can strongly protect neuronal cells against oxidative damage. Sci. Rep. 2020, 10, 7283. [CrossRef]

102. Mueck, A.O.; Seeger, H.; Lippert, T.H. Estradiol metabolism and malignant disease. Maturitas 2002, 43, 1-10. [CrossRef]

103. Anh, N.H.; Long, N.P.; Kim, S.J.; Min, J.E. Steroidomics for the prevention, assessment, and management of cancers: A systematic review and functional analysis. Metabolites 2019, 9, 199. [CrossRef]

104. Seeger, H.; Deuringer, F.-U.; Wallwiener, D.; Mueck, A.O. Breast cancer risk during HRT: Influence of estradiol metabolites on breast cancer and endothelial cell proliferation. Maturitas 2004, 49, 235-240. [CrossRef]

105. Fuhrman, B.J.; Schairer, C.; Gail, M.H.; Boyd-Morin, J. Estrogen metabolism and risk of breast cancer in postmenopausal women. J. Nat. Cancer Inst. 2012, 104, 326-339. [CrossRef]

106. Fishman, J.; Cox, R.I.; Gallagher, T.F. 2-Hydroxyestrone: A new metabolite of estradiol in man. Archiv. Biochem. Biophys. 1960, 90, 318-319. [CrossRef]

107. Taylor, H.C. The present status of gynecologic endocrine therapy. Bull. N. Y. Acad. Med. 1938, 14, 608-634. [PubMed]

108. Marrian, G.F. The conjugated estrogens. Cold Spring Harb. Symp. Quant. Biol. 1937, 5, 16-24. [CrossRef]

109. Dembitsky, V.M.; Savidov, N.; Poroikov, V.V.; Gloriozova, T.A.; Imbs, A.B. Naturally occurring aromatic steroids and their biological activities. Appl. Microbiol. Biotechnol. 2018, 102, 4663-4674. [CrossRef]

110. De Riccardis, F.; Minale, L.; Riccio, R.; Giovannitti, B.; Iorizzi, M.; Debitus, C. Phosphated and sulfated marine polyhydroxylated steroids fromthe starfish Tremaster novaecaledoniae. Gazz. Chim. Ital. 1993, 123, 79-86.

111. Dembitsky, V.M.; Gloriozova, T.A.; Savidov, N. Steroid phosphate esters and phosphonosteroids and their biological activities. Appl. Microbiol. Biotechnol. 2018, 102, 7679-7692. [CrossRef]

112. Delrio, G.; Botte, V. Testosterone 17-phosphate and 19-nortestosterone 17-phosphate as substrate for rabbit prostate phosphatases. Biochim. Biophys. Acta 1970, 218, 327-332. [CrossRef]

113. Kokado, A.; Tsuji, A.; Maeda, M. Chemiluminescence assay of alkaline phosphatase using cortisol-21-phosphate as substrate and its application to enzyme immunoassays. Anal. Chim. Acta 1997, 337, 335-340. [CrossRef]

114. Ellam, T.J.; Chico, T.J. Phosphate: The new cholesterol? The role of the phosphate axis in non-uremic vascular disease. Atherosclerosis 2012, 220, 310-318. [CrossRef]

115. Davis, S.C.; Szoka, F.C., Jr. Cholesterol phosphate derivatives: Synthesis and incorporation into a phosphatase and calciumsensitive triggered release liposome. Bioconjug. Chem. 1998, 9, 783-792. [CrossRef]

116. Sachs-Barrable, K.; Darlington, J.W.; Wasan, K.M. The effect of two novel cholesterol-lowering agents, disodium ascorbyl phytostanol phosphate and nanostructured aluminosilicate on the expression and activity of P-glycoprotein within Caco-2 cells. Lipids Health Dis. 2014, 13, 153-163. [CrossRef]

117. Kutney, J.P.; Pritchard, H.P.; Lukic, T. Novel Compounds and Compositions Comprising Sterols and/or Stanols and Cholesterol Biosynthesis Inhibitors and Use Thereof in Treating or Preventing a Variety of Diseases and Conditions. Europe Patent EP1644399A2, 7 September 2003.

118. Gunnarsson, P.O.; Norlén, B.J. Clinical pharmacology of polyestradiol phosphate. Prostate 1988, 13, 299-304. [CrossRef]

119. Vil, V.; Gloriozova, T.A.; Terentev, A.O.; Zhukova, N.V.; Dembitsky, V.M. Highly oxygenated isoprenoid lipids derived from terrestrial and aquatic sources: Origin, structures, and biological activities. Vietnam J. Chem. 2019, 57, 1-15. [CrossRef]

120. Vil, V.A.; Terentev, A.O.; Savidov, N.; Gloriozova, T.A.; Poroikov, V.V.; Pounina, T.A.; Dembitsky, V.M. Hydroperoxy steroids and triterpenoids derived from plant and fungi: Origin, structures and biological activities. J. Steroid Biochem. Mol. Biol. 2019, 190, 76-87. [CrossRef]

121. Savidov, N.; Gloriozova, T.A.; Poroikov, V.V.; Dembitsky, V.M. Highly oxygenated isoprenoid lipids derived from fungi and fungal endophytes: Origin and biological activities. Steroids 2018, 140, 114-124. [CrossRef]

122. Vil, V.A.; Gloriozova, T.A.; Terentev, A.O.; Savidov, N.; Dembitsky, V.M. Hydroperoxides derived from marine sources: Origin and biological activities. Appl. Microbiol. Biotechnol. 2019, 103, 1627-1642. [CrossRef]

123. Dembitsky, V.M.; Gloriozova, T.A.; Poroikov, V.V. Naturally occurring marine $\alpha, \beta$-epoxy steroids: Origin and biological activities. Vietnam J. Chem. 2018, 56, 409-433. [CrossRef]

124. Rashidi, B.; Hoseini, Z.; Sahebkar, A.; Mirzaei, H. Anti-atherosclerotic effects of vitamins D and E in suppression of atherogenesis. J. Cell. Physiol. 2017, 232, 2968-2976. [CrossRef]

125. Kutner, A.; Brown, G. Vitamins D: Relationship between structure and biological activity. Int. J. Mol. Sci. 2018, 19, 2119. [CrossRef]

126. Dusso, A.S.; Brown, A.J.; Slatopolsky, E. Vitamin D. Am. J. Physiol. Renal. Physiol. 2005, 289, F8-F28. [CrossRef]

127. Perez-Lopez, F.R. Vitamin D: The secosteroid hormone and human reproduction. Gynecolog. Endocrinol. 2007, 23, 13-24. [CrossRef] [PubMed] 
128. Ermolenko, E.V.; Imbs, A.B.; Gloriozova, T.A.; Poroikov, V.V.; Sikorskaya, T.V.; Dembitsky, V.M. Chemical diversity of soft coral steroids and their pharmacological activities. Mar. Drugs 2020, 20, 613. [CrossRef] [PubMed]

129. Grishko, V.V.; Galaiko, N.V. Structural diversity, natural sources and pharmacological potential of naturally occurring A-secotriterpenoids studies. Nat. Prod. Chem. 2016, 51, 51-149.

130. Sica, D.; Musumeci, D. Secosteroids of marine origin. Steroids 2004, 69, 743-756. [CrossRef] [PubMed]

131. Wu, S.H.; Luo, X.D.; Ma, Y.B.; Liu, Y.K.; Wu, D.G.; Zhao, B.; Lu, Y.; Zheng, Q.T. Two novel secoergosterols from the fungus Tylopilus plumbeoviolaceus. J. Nat. Prod. 2000, 63, 534-536. [CrossRef] [PubMed]

132. Zhao, Z.Z.; Chen, H.P.; Huang, Y.; Zhang, S.B.; Li, Z.H.; Feng, T.; Liu, J.K. Bioactive polyketides and 8,14-seco-ergosterol from fruiting bodies of the ascomycete Daldinia childiae. Phytochemistry 2017, 142, 68-75. [CrossRef] [PubMed]

133. Cui, C.M.; Li, X.M.; Meng, L.; Li, C.S.; Huang, C.G.; Wang, B.G. 7-Nor-ergosterolide, a pentalactone-containing norsteroid and related steroids from the marine-derived endophytic Aspergillus ochraceus EN-31. J. Nat. Prod. 2010, 73, 1780-1784. [CrossRef]

134. Onodera, H.; Ichimura, M.; Baba, K.; Agatsuma, T.; Sasho, S.; Suzuki, M.; Iwamoto, S.; Kakita, S. PCT Int. Appl. WO 2009096445, Nerve Trunk Cell Propagation Accelerator, 06.08.2009; Kyowa Hakko Kirin Co., Ltd.: Tokyo, Japan.

135. Kazlauskas, R.; Murphy, P.T.; Ravi, B.N.; Sanders, R.L.; Wells, R.J. Spermidine derivatives and 9,11-secosteroids from a soft coral (Sinularia sp.). Austral. J. Chem. 1982, 35, 69-75. [CrossRef]

136. Bonini, C.; Cooper, C.B.; Kazlauskas, R.; Wells, R.J.; Djerassi, C. Minor and trace sterols in marine invertebrates. 41. Structure and stereochemistry of naturally occurring 9,11-seco sterols. J. Org. Chem. 1983, 48, 2108-2111. [CrossRef]

137. Weng, J.R.; Chiu, C.F.; Sheu, J.H. A sterol from soft coral induces apoptosis and autophagy in MCF-7 breast cancer cells. Mar. Drugs 2018, 16, 238. [CrossRef]

138. Chang, Y.C.; Lai, K.H.; Kumar, S.; Chen, P.J.; Wu, Y.H.; Lai, C.L. 1HNMR-Based Isolation of Anti-Inflammatory 9,11-secosteroids from the octocoral Sinularia leptoclados. Mar. Drugs 2020, 18, 271. [CrossRef]

139. Hirsch, A.L. Industrial aspects of vitamin D. In Vitamin, D., 3rd ed.; Feldman, D., Pike, J.W., Adams, J.S., Eds.; Academic Press: San Diego, CA, USA, 2011; pp. 73-93.

140. Teichmann, A.; Dutta, P.C.; Staffas, A.; Jagerstäd, M. Sterol and vitamin D2 concentrations in cultivated and wild grown mushrooms: Effect of UV radiation. LWT Food Sci. Technol. 2007, 40, 815-822. [CrossRef]

141. Koyyalamudi, S.R.; Jeong, S.C.; Song, C.H.; Cho, K.Y.; Pang, G. Vitamin D2 formation and bioavailability from Agaricus bisporus button mushrooms treated with ultraviolet irradiation. J. Agric. Food Chem. 2009, 57, 3351-3355. [CrossRef]

142. Koyyalamudi, S.R.; Jeong, S.C.; Pang, G.; Teal, A.; Biggs, T. Concentration of vitamin D2 in white button mushrooms (Agaricus bisporus) exposed to pulsed UV light. J. Food Comp. Anal. 2011, 24, 976-979. [CrossRef]

143. Phillips, K.M.; Ruggio, D.M.; Horst, R.L.; Minor, B.; Simon, R.R.; Feeney, M.J.; Byrdwell, W.C.; Haytowitz, D.B. Vitamin D and sterol composition of 10 types of mushrooms from retail suppliers in the United States. J. Agric. Food Chem. 2011, 59, 7841-7853. [CrossRef]

144. Jasinghe, V.J.; Perera, C.O. Ultraviolet irradiation: The generator of vitamin D2 in edible mushrooms. Food Chem. 2006, 95, 638-643. [CrossRef]

145. Roberts, J.S.; Teichert, A.; McHugh, T.H. Vitamin D2 formation from post-harvest UV-B treatment of mushrooms (Agaricus bisporus) and retention during storage. J. Agric. Food Chem. 2008, 56, 4541-4544. [CrossRef]

146. Shen, Y.C.; Cheng, Y.B.; Kobayashi, J.; Kubota, T.; Takahashi, Y.; Mikami, Y.; Ito, J.; Lin, Y.S. Nitrogen-containing verticillene diterpenoids from the Taiwanese soft coral Cespitularia taeniata. J. Nat. Prod. 2007, 70, 1961-1965. [CrossRef]

147. Lakshmi, V.; Kumar, R. Metabolites from Sinularia species. Nat. Prod. Res. 2009, 23, 801-850. [CrossRef]

148. Kulda, V. Vitamin D metabolism. Vnitr Lek. 2012, 58, 400-404.

149. Windaus, A.; Schenck, F.R.; Werder, F.V. The anti-rachitically active irradiation product from 7-dehydro-cholesterol. Hoppe-Seyler's Zeitsch. Physiol. Chem. 1936, 241, 100-103. [CrossRef]

150. Wanga, T.; Bengtsson, G.; Kärnefeltd, I.; Björn, L.O. Provitamins and vitamins D2 and D3 in Cladina spp. over a latitudinal gradient: Possible correlation with UV levels. J. Photochem. Photobiol. 2001, 62B, 118-122. [CrossRef]

151. Horst, R.L.; Reinhardt, T.A.; Russell, J.R.; Napoli, J.L. The isolation and identification of vitamin D2 and vitamin D3 from Medicago sativa (Alfalfa plant). Arch. Biochem. Biophys. 1984, 231, 67-71. [CrossRef]

152. World Health Organization. World Health Organization Model List of Essential Medicines: 21st List 2019; World Health Organization: Geneva, Switzerland, 2019.

153. Trump, D.L.; Aragon-Ching, J.B. Vitamin D in prostate cancer. Asian J. Androl. 2018, 20, 244-252. [CrossRef]

154. Laaksi, I. Vitamins, infectious and chronic disease during adulthood and aging Vitamin D and respiratory infection in adults. Proceed. Nutr. Soc. 2012, 71, 90-97. [CrossRef]

155. Saikia, S.; Kolita, B.; Dutta, P.P.; Dutta, D.J.; Neipihoi, S.; Nath, S. Marine steroids as potential anticancer drug candidates: In silico investigation in search of inhibitors of Bcl-2 and CDK-4/Cyclin D1. Steroids 2015, 102, 7-16. [CrossRef]

156. Dembitsky, V.M. Anticancer activity of natural and synthetic acetylenic lipids. Lipids 2006, 41, 883-924. [CrossRef]

157. Zhang, H.; Zhao, Z.; Wang, H. Cytotoxic natural products from marine sponge-derived microorganisms. Mar. Drugs 2017, 15, 68. [CrossRef] [PubMed]

158. Mioso, R.; Marante, F.J.T.; Bezerra, R.D.S.; Borges, F.V.P.; Santos, B.V.; Laguna, I.H.B.D. Cytotoxic compounds derived from marine sponges, A review (2010-2012). Molecules 2017, 22, 208. [CrossRef] [PubMed] 
159. Dembitsky, V.M.; Rezanka, T.; Srebnik, M. Lipid compounds of freshwater sponges: Family Spongillidae, class Demospongiae. Chem. Phys. Lipids 2003, 123, 117-155. [CrossRef]

160. Xu, S.; Liao, X.; Du, B.; Zhou, X.; Huang, Q.; Wu, C. A series of new 5,6-epoxysterols from a Chinese sponge Ircinia aruensis. Steroids 2008, 73, 568-573.

161. Li, T.; Wang, N.; Zhang, T.; Zhang, B.; Sajeevan, T.P.; Valsamma, J.; Armstrong, L.; He, S.; Yan, X.; Naman, C.B. A systematic review of recently reported marine derived natural product kinase inhibitors. Mar. Drugs 2019, 17, 493. [CrossRef]

162. Zhang, H.J.; Yi, Y.H.; Yang, F.; Chen, W.S.; Lin, H.W. Sesterterpenes and a new sterol from the marine sponge Phyllospongia foliascens. Molecules 2010, 15, 834-841.

163. Afiyatullov, S.S.; Kalinovsky, A.I.; Antonov, A.S.; Ponomarenko, L.P. Isolation and structures of erylosides from the Carribean sponge Erylus goffrilleri. J. Nat. Prod. 2007, 70, 1871-1877. [CrossRef]

164. Anjaneyulu, A.S.R.; Krishna Murthy, M.V.R.; Gowri, P.M. Novel epoxy steroids from the Indian ocean soft coral Sarcophyton crassocaule. J. Nat. Prod. 2000, 63, 112-118.

165. Funel, C.; Berrué, F.; Roussakis, C.; Fernandez Rodriguez, R.; Amade, P. New cytotoxic steroids from the Indian ocean sponge Axinella cf. bidderi. J. Nat. Prod. 2004, 67, 491-494.

166. Dembitsky, V.M. Bioactive fungal endoperoxides. Med. Mycol. 2015, 1, 1-7.

167. Dembitsky, V.M. Astonishing diversity of natural peroxides as potential therapeutic agents. J. Mol. Genet. Med. $2015,9,1000163$.

168. Dembitsky, V.M. Bioactive peroxides as potential therapeutic agents. Eur. J. Med. Chem. 2008, 43, $223-251$.

169. Kyasa, S.K. New Methods for Synthesis of Organic Peroxides and Application of Peroxide Electrophiles to Synthesis of Functionalized Ethers. Ph.D. Thesis, University of Nebraska-Lincoln, Lincoln, NE, USA, 2005.

170. Klussmann, M. Alkenyl and aryl peroxides. Chemistry 2018, 24, 4480-4496.

171. Dembitsky, V.M.; Gloriozova, T.A.; Poroikov, V.V. Natural peroxy anticancer agents. Mini-Rev. Med. Chem. 2007, 7, 571-589. [CrossRef] [PubMed]

172. Dembitsky, V.; Shkrob, I.; Hanus, L.O. Ascaridole and related peroxides from the genus Chenopodium. Biomed. Pap. Med. Fac. Univ. Palacky Olomouc Czech Repub. 2008, 152, 209-215. [CrossRef] [PubMed]

173. Liu, D.Z.; Liu, J.K. Peroxy natural products. Nat. Prod. Bioprospect. 2013, 3, 161-206. [CrossRef]

174. Thao, N.P.; Cuong, N.X.; Luyen, B.T.T.; Nam, N.H. Steroidal constituents from the starfish Astropecten polyacanthus and their anticancer effects. Chem. Pharm. Bull. 2013, 61, 1044-1051. [CrossRef]

175. Seo, Y.W.; Rho, J.R.; Cho, K.W.; Sim, C.J.; Shin, J.H. Isolation of epidioxysteroids from a sponge of the genus Tethya. Bull. Korean Chem. Soc. 1997, 18, 631-635.

176. Gunatilaka, A.A.L.; Gopichand, Y.; Schmitz, F.J.; Djerassi, C. Minor and trace sterols in marine invertebrates. 26. Isolation and structure elucidation of nine new 5,8-epidoxy sterols from four marine organisms. J. Org. Chem. 1981, 46, 3860-3866. [CrossRef]

177. Gauvin, A.; Smadja, J.; Aknin, M.; Faure, R.; Gaydou, E.M. Isolation of bioactive $5 \alpha, 8 \alpha$-epidioxy sterols from the marine sponge Luffariella cf. variabilis. Can. J. Chem. 2000, 78, 986-992. [CrossRef]

178. Sheikh, Y.M.; Djerassi, C. Steroids from sponges. Tetrahedron 1974, 30, 4095-4103. [CrossRef]

179. Zheng, W.; Liu, T.; Xiang, X.; Gu, Q. Sterol composition in field-grown and cultured mycelia of Inonotus obliquus. Yaoxue Xuebao 2007, 42, 750-756.

180. Zhang, Y.; Pei, L.; Gao, L.; Huang, Q.; Qi, J. A neuritogenic compound from Tremella fuciformis. Zhongguo Zhong Yao Za Zhi 2011, 36, 2358-2360.

181. Shi, X.W.; Li, X.J.; Gao, J.M.; Zhang, X.C. Fasciculols H and I, two lanostane derivatives from Chinese mushroom Naematoloma fasciculare. Chem. Biodivers. 2011, 8, 1864-1870. [CrossRef] [PubMed]

182. Yaoita, Y.; Amemiya, K.; Ohnuma, H.; Furumura, K.; Masaki, A.; Matasuki, T.; Kikuchi, M. Sterol constituents from five edible mushrooms. Chem. Pharm. Bull. 1998, 46, 944-950. [CrossRef]

183. Yue, J.M.; Chen, C.N.; Lin, Z.W.; Sun, H.D. Sterols from the fungus Lactarium volemus. Phytochemistry 2001, 56, 801-806. [CrossRef]

184. Zang, M.; Ying, J.Z. Economic Fungi in the South West of China; Scientific Press: Beijing, China, 1994.

185. Greca, M.D.; Fiorentino, A.; Molinaro, A.; Monaco, P.; Previtera, L. Hydroperoxysterols in Arum italicum. Nat. Prod. Lett. 1994, 5 , 7-14. [CrossRef]

186. Wu, S.B.; Bao, Q.Y.; Wang, W.X.; Zhao, Y.; Xia, G. Cytotoxic triterpenoids and steroids from the bark of Melia azedarach. Planta Med. 2011, 77, 922-928. [CrossRef]

187. Ponce, M.A.; Ramirez, J.A.; Galagovsky, L.R.; Gros, E.G.; Erra-Balsells, R. A new look into the reaction between ergosterol and singlet oxygen in vitro. Photochem. Photobiol. Sci. 2002, 1, 749-756. [CrossRef]

188. Bocking, T.; Barrow, K.D.; Netting, A.G.; Chilcott, T.C.; Coster, H.G.L.; Hofer, M. Effects of singlet oxygen on membrane sterols in the yeast Saccharomyces cerevisiae. Eur. J. Biochem. 2000, 267, 1607-1618. [CrossRef]

189. Banskota, A.H.; Tezuka, Y.; Phung, L.K.; Tran, K.Q.; Saiki, I. Cytotoxic cycloartane-type triterpenes from Combretum quadrangulare. Bioorg. Med. Chem. Lett. 1998, 8, 3519-3524. [CrossRef]

190. Bankota, A.H.; Tezuka, Y.; Tran, K.Q.; Tanaka, K.; Saiki, I.; Kadota, S. Thirteen novel cycloartane-type triterpenes from Combretum quadrangulare. J. Nat. Prod. 2000, 63, 57-64. [CrossRef]

191. Roy, R.; Raj, K.; Singh, K.; Jash, S.K.; Sarkar, A.; Gorai, D. Combretum quadrangulare (Combretaceae): Phytochemical constituents and biological activity. Indo Amer. J. Pharm. Res. 2014, 4, 3416-3427. 
192. Asai, T.; Hara, N.; Fujimoto, Y. Fatty acid derivatives and dammarane triterpenes from the glandular trichome exudates of Ibicella lutea and Proboscidea louisiana. Phytochemistry 2010, 71, 877-894. [CrossRef]

193. Lee, I.S.; Oh, S.R.; Ahn, K.S.; Lee, H.K. Semialactone, isofouquierone peroxide and fouquierone, three new dammarane triterpenes from Rhus javanica. Chem. Pharm. Bull. 2001, 49, 1024-1029. [CrossRef]

194. Abdel Bar, F.M.; Zaghloul, A.M.; Bachawal, S.V.; Sylvester, P.W.; Ahmad, K.F.; El Sayed, K.A. Antiproliferative triterpenes from Melaleuca ericifolia. J. Nat. Prod. 2008, 71, 1787-1790. [CrossRef]

195. Chiamg, Y.M.; Kuo, Y.H. New peroxy triterpenes from the aerial roots of Ficus macrocarpa. J. Nat. Prod. 2001, 64, 436-439. [CrossRef]

196. Sikorsky, T.V.; Ermolenko, E.V.; Gloriozova, T.A.; Dembitsky, V.M. Mini Review: Anticancer activity of diterpenoid peroxides. Vietnam J. Chem. 2020, 58, 273-280. [CrossRef]

197. Dembitsky, V.M.; Yaremenko, I.A. Stable and unstable 1,2-dioxolanes: Origin, synthesis, and biological activities. Sci. Synth. Knowl. Updates 2020, 38, 277-321. [CrossRef]

198. Dembitsky, V.M.; Vil, V.A. Medicinal chemistry of stable and unstable 1,2-dioxetanes: Origin, formation, and biological activities. Sci. Synth. Knowl. Updates 2020, 38, 333-381. [CrossRef]

199. Phillipson, J.D.; Wright, C.W. Antiprotozoal agents from plant sources. Planta Med. 1991, 57, S53-S59. [CrossRef] [PubMed]

200. Moss, G.P. The nomenclature of steroids. Eur. J. Biochem. 1989, 186, 429-458.

201. Burger, A. Cyclopropane compounds of biological interest. Prog. Drug Res. 1971, 15, 227-270.

202. Schoenheimer, R.; Evans, E.A., Jr. The chemistry of the steroids. Ann. Rev. Biochem. 1937, 6, 139-162. [CrossRef]

203. Dembitsky, V.M.; Gloriozova, T.A. Astonishing diversity of carbon-bridged steroids and their biological activities: A brief review. Eur. J. Biotechnol. Biosci. 2018, 6, 6-23.

204. Jacobs, H.J.C. Photochemistry of conjugated trienes: Vitamin D revisited. Pure Appl. Chem. 1995, 67, 63-70. [CrossRef]

205. Kalaras, M.D. Production of Ergocalciferol (Vitamin D2) and Related Sterols in Mushrooms with Exposure to Pulsed Ultraviolet Light. Ph.D. Thesis, Pennsylvania State University, State College, PA, USA, January 2012.

206. Mitome, H.; Shirato, N.; Hoshino, A.; Miyaoka, H.; Yamada, Y.; Yamada, Y.; Van Soest, R.W.M. New polyhydroxylated sterols stylisterols A-C and a novel 5, 19-cyclosterol hatomasterol from the Okinawan marine sponge Stylissa sp. Steroids 2005, 70, 63-70. [CrossRef]

207. Calabro, K.; Kalahroodi, E.L.; Rodrigues, D.; Díaz, C.; Cruz, M.D.L.; Cautain, B.; Laville, R. Poecillastrosides, steroidal saponins from the Mediterranean deep-sea sponge Poecillastra compressa (Bowerbank, 1866). Mar. Drugs 2017, 15, 199. [CrossRef]

208. Giner, J.-L.; Gunasekera, S.P.; Pomponi, S.A. Sterols of the marine sponge Petrosia weinbergi: Implications for the absolute configurations of the antiviral orthoesterols and weinbersterols. Steroids 1999, 64, 820-824. [CrossRef]

209. HXinping, H.; Xiaobin, Z.; Liping, D.; Zhiwei, D.; Wenhan, L. Cycloartane triterpenes from marine green alga Cladophora fascicularis. Chin. J. Ocean. Limnol. 2006, 24, 443-448. [CrossRef]

210. Tung, N.H.; Van Minh, C.; Ha, T.T.; Van Kiem, P.; Huong, H.T. C29-Sterols with a cyclopropane ring at C-25 and 26 from the Vietnamese marine sponge Ianthella sp. and their anticancer properties. Bioorg. Med. Chem. Lett. 2009, 19, 4584-4588. [CrossRef]

211. Gauvin, A.; Smadja, J.; Aknin, M.; Gaydou, E.M. Cyclopropane-containing sterols in the marine sponge Petrosia spheroïda. Comp. Biochem. Physiol. 1998, 121B, 451-456. [CrossRef]

212. Abdjul, D.B.; Yamazaki, H.; Takahashi, O.; Kirikoshi, R.; Ukai, K.; Namikoshi, M. Isopetrosynol, a new protein tyrosine phosphatase $1 \mathrm{~B}$ inhibitor, from the marine sponge Halichondria cf. panicea collected at Iriomote Island. Chem. Pharm. Bull. 2016, 64, 733-736. [CrossRef]

213. Umeyama, A.; Ito, S.; Yoshigaki, A.; Arihara, S. Two new 26,27-cyclosterols from the marine sponge Strongylophora corticate. J. Nat. Prod. 2000, 63, 1540-1542. [CrossRef]

214. Minale, L.; Riccio, R.; Scalona, O.; Sodano, G.; Fattorusso, E.; Magno, S.; Mayol, L.; Santacroce, C. Metabolism in Porifera. VII. Conversion of [7,7-3H2]-fucosterol into calysterol by the sponge Calyx niceaensis. Experientia 1977, 33, 1550-1552. [CrossRef]

215. Fatturosso, E.; Magno, S.; Mayol, L.; Santacrove, C.; Sioa, D. Calysterol: A C-29 cyclopropene-containing marine sterol from the sponge Calyx nicaensis. Tetrahedron 1975, 31, 1715-1716. [CrossRef]

216. O'Connor, J.M.; Pu, L.; Chadha, R.K. Metallacycle annelation: Reaction of a metallacycle alpha-substituent and a vinylidene ligand to give a bicyclic metallalactone complex. J. Am. Chem. Soc. 1990, 112, 9627-9628. [CrossRef]

217. Li, L.N.; Li, H.T.; Lang, R.W.; Itoh, T.; Sica, D.; Djerassi, C. Minor and trace sterols in marine invertebrates. 31. Isolation and structure elucidation of $23 \mathrm{H}$-isocalysterol, a naturally occurring cyclopropene. Some comparative observations on the course of hydrogenolytic ring opening of steroidal cyclopropenes and cyclopropanes. J. Am. Chem. Soc. 1982, 104, 6726-6732.

218. Gunasekera, S.P.; Cranick, S.; Pomponi, S.A. Pomponi, New sterol ester from a deep-water marine sponge, Xestospongia sp. J. Nat. Prod. 1991, 54, 1119-1122. [CrossRef]

219. Dembitsky, V.M. Natural neo acids and neo alkanes: Their analogs and derivatives. Lipids 2006, 41, 309-340. [CrossRef]

220. Bisel, P.; Al-Momani, L.; Müller, M. The tert-butyl group in chemistry and biology. Org. Biomol. Chem. 2008, 6, 2655-2665. [CrossRef]

221. Dembitsky, V.M. Alkoxylipids of the Organic World. Chemistry and Biology. Ph.D. Thesis, Lomonosov University of Fine Chemical Technology, Moscow, Russia, 1996.

222. Akihisa, A.; Inada, Y.; Ghosh, P. Compositions of triterpene alcohols of seeds and mature plants of family Cucurbitaceae. J. Am. Oil Chem. Soc. 1988, 65, 607-610. [CrossRef] 
223. Akihisa, T.; Tamura, T.; Matsumoto, T. 24-Methylene-25-methyllathosterol: A sterol from Sicyos angulatus. Phytochemistry 1987, 26, 575-577. [CrossRef]

224. Rahimi, R.; Shams-Ardekani, M.R.; Abdollahi, M. A review of the efficacy of traditional Iranian medicine for inflammatory bowel disease. World J. Gastroenterol. 2010, 16, 4504-4514. [CrossRef]

225. Bojić, M.; Maleš, Ž.; Antolić, A.; Babić, I.; Tomičić, M. Antithrombotic activity of flavonoids and polyphenols rich plant species. Acta Pharma. 2019, 69, 483-495. [CrossRef]

226. Sestili, P.; Ismail, T.; Calcabrini, C.; Guescini, M.; Catanzaro, E.; Turrini, E. The potential effects of Ocimum basilicum on health: A review of pharmacological and toxicological studies. Expert Opin. Drug Metab. Toxicol. 2018, 14, 679-692. [CrossRef]

227. Devi, P.U. Radioprotective, anticarcinogenic and antioxidant properties of the Indian holy basil, Ocimum sanctum (Tulasi). Indian J. Exp. Biol. 2001, 39, 185-190.

228. Ch, M.A.; Naz, S.B.; Sharif, A.; Akram, M.; Saeed, M.A. Biological and pharmacological properties of the sweet basil (Ocimum basilicum). Br. J. Pharm Res. 2015, 7, 330-339. [CrossRef]

229. Siddiqui, B.S.; Aslam, H.; Ali, S.T. Two new triterpenoids and a steroidal glycoside from the aerial parts of Ocimum basilicum. Chem. Pharm Bull. 2007, 55, 516-519. [CrossRef]

230. Li, Y. Stereo Chemical Studies on the Metabolism of Sterols by Saccharomyces Cerevisiae Strain GL7. Ph.D. Thesis, Texas Tech University, Lubbock, TX, USA, 1996.

231. Liu, J.; Nes, W.D. Steroidal triterpenes: Design of substrate-based inhibitors of ergosterol and sitosterol synthesis. Molecules 2009, 14, 4690-4706. [CrossRef]

232. Ishibashi, M.; Yamagishi, E.; Kobayashi, J. Topsentinols A-J, new sterols with highly branched side chains from marine sponge Topsentia sp. Chem. Pharm Bull. 1997, 45, 1435-1438. [CrossRef]

233. Nojo, R.; Echigo, S.; Hara, N.; Fujimoto, Y. C-24 stereochemistry of marine sterols: (22E)-25,28-dimethylstigmasta-5,22,28-trien-3 $\beta$ ol and 25,28-dimethylstigmasta-5,28-dien-3ß-ol. Nat. Prod. Commun. 2014, 9, 1699-1704. [CrossRef]

234. Li, X.; Djerassi, C. Minor and trace sterols in marine invertebrates 40. Structure and synthesis of axinyssasterol, 25-methylfucosterol and 24-ethyl-24-methylcholesterol-Novel sponge sterols with highly branched side chains. Tetrahedron Lett. 1983, 24, 665-668. [CrossRef]

235. Shubina, L.K.; Makar'eva, T.N.; Stonik, V.A. Steroidal compounds of marine sponges. III. 24-Ethyl-25-methylcholesta-5,22-dien3b-ol-A novel marine sterol from the sponge Halichondria sp. Khim. Prir. Soedin. 1984, 4, 464-467.

236. Shubina, L.K.; Makar'eva, T.N.; Stonik, V.A. Steroidal compounds of marine sponges. VI. Sterols and their derivatives from Trachyopsis aplysinoides. Khim. Prir. Soedin. 1985, 5, 715-716.

237. Fusetani, N.; Matsunaga, S.; Konosu, S. Bioactive marine metabolites. II. Halistanol sulfate, an antimicrobial novel steroid sulfate from the marine sponge Halichondria cf. moorei Bergquist. Tetrahedron Lett. 1981, 22, 1985-1988. [CrossRef]

238. Gulavita, N.K.; Wright, A.E.; Kelly-Borges, M.; Longley, R.E. Eryloside E from an Atlantic sponge Erylus goffrilleri. Tetrahedron Lett. 1994, 35, 4299-4302. [CrossRef]

239. Ebada, S.S.; Lin, W.H.; Proksch, P. Bioactive sesterterpenes and triterpenes from marine sponges: Occurrence and pharmacological significance. Marine Drugs 2010, 8, 313-346. [CrossRef]

240. Morrison-Gardiner, S. Dominant fungi from Australian reefs. Fungal Divers. 2002, 9, 105-121.

241. Jones, E.B.G.; Sakayaroj, J.; Suetrong, S.; Somrithipol, S.; Pang, K.L. Classification of marine Ascomycota, anamorphic taxa and Basidiomycota. Fungal Divers. 2009, 35, 1-187.

242. El-Bondkly, E.A.M.; El-Bondkly, A.A.M.; El-Bondkly, A.A.M. Marine endophytic fungal metabolites: A whole new world of pharmaceutical therapy exploration. Heliyon 2021, 7, e06362. [CrossRef]

243. Wang, S.K.; Dai, C.F.; Duh, C.Y. Cytotoxic pregnane steroids from the Formosan Soft Coral Stereonephthya crystalliana. J. Nat. Prod. 2006, 69, 103-106. [CrossRef]

244. Murillo-Alvarez, J.; Encarnacion-Dimayuga, R. New bioactive pregnadiene-derived glycosides from the gulf of California gorgonian Muricea cf. austera. Pharm. Biol. 2003, 41, 531-535. [CrossRef]

245. Anjaneyulu, A.S.R.; Rao, V.L.; Sastry, V.G. A new spiroketal steroid from Gorgonella umbraculum. Nat. Prod. Res. 2003, 17, 149-152. [CrossRef] [PubMed]

246. Seo, Y.; Rho, J.R.; Cho, K.W.; Shin, J. Isolation of new steroidal hemiacetals from the gorgonian Euplexaura anastomosans. J. Nat. Prod. 1996, 59, 1196-1199. [CrossRef]

247. Huang, C.Y.; Chang, C.W.; Sheu, J.H. Bioactive steroids from the Formosan soft coral Umbellulifera petasites. Mar. Drugs 2016, 14, 180. [CrossRef]

248. Blunt, J.W.; Copp, B.R.; Munro, M.H.G.; Northcote, P.T.; Prinsep, M.R. Marine natural products. Nat. Prod. Rep. 2005, $22,15-61$. [CrossRef]

249. Ngoc, N.T.; Huong, P.T.M.; Thanh, N.V.; Cuong, N.X. Steroid constituents from the soft coral Sinularia nanolobata. Chem. Pharm. Bull. 2016, 64, 1417-1419. [CrossRef] [PubMed]

250. Gebreyesus, T.; Stoilov, I.; Luo, F.T.; Djerassi, C. Minor and trace sterols in marine invertebrates 55. The isolation, structure elucidation and synthesis of ergosta-5,24(28),25-trien-3-ol. Steroids 1985, 45, 447-452. [CrossRef]

251. Chao, C.H.; Chou, K.J.; Huang, C.Y.; Wen, Z.H.; Hsu, C.H. Steroids from the soft coral Sinularia crassa. Mar. Drugs 2012, 10, 439-450. [CrossRef] 
252. Mariottini, G.L. The role of cnidaria in drug discovery. In The Cnidaria, Past, Present and Future; Goredo, S., Dubinsky, Z., Eds.; Springer: Cham, Switzerland, 2016.

253. Ilhan, H.A.; Pulat, C.C. Cytotoxic and antitumor compounds from marine invertebrates. Encycl. Mar. Biotechnol. 2020, 4 , 2529-2584. [CrossRef]

254. Ngoc, N.T.; Huong, P.T.M.; Van Thanh, N.; Chia, N.T.P.C. Cytotoxic steroids from the Vietnamese soft coral Sinularia conferta. Chem. Pharm. Bull. 2017, 65, 300-305. [CrossRef]

255. Cuíng, N.X.; Nhiem, N.X.; Thanh, N.V. Review of chemistry and biological activity studies some marine species in Vietnam in the period 2013-2017. Vietnam J. Chem. 2018, 56, 1-19.

256. Cardoso-Martínez, F.; de la Rosa, J.M.; Díaz-Marrero, A.R.; Darias, J. Oxysterols from an octocoral of the genus Gorgonia from the eastern Pacific of Panama. J. RSC Adv. 2013, 6, 38579-38591. [CrossRef]

257. Yan, X.; Liu, J.; Leng, X.; Ouyang, H. Chemical diversity and biological activity of secondary metabolites from soft coral genus Sinularia since 2013. Mar. Drugs 2021, 19, 335. [CrossRef]

258. Radhika, P. Chemical constituents and biological activities of the soft corals of genus Cladiella: A review. Biochem. Syst. Ecol. 2006, 34, 781-789. [CrossRef]

259. Zubair, M.S.; Al-Footy, K.O.; Ayyad, S.-E.N.; Al-Lihaibi, S.S.; Alarif, W.M. A review of steroids from Sarcophyton species. Nat. Prod. Res. 2016, 30, 869-879. [CrossRef]

260. Amir, F.; Koay, Y.C.; Yam, W.S. Chemical constituents, and biological properties of the marine soft coral Nephthea: A review (Part 1). Trop. J. Pharm. Res. 2012, 11, 485-498.

261. Amir, F.; Koay, Y.C.; Yam, W.S. Chemical constituents, and biological properties of the marine soft coral Nephthea: A review (Part 2). Trop. J. Pharm. Res. 2012, 11, 499-517.

262. Baulieu, E.E. Steroid hormones in the brain: Several mechanisms? Steroid hormone regulation of the brain. In Proceedings of the International Symposium Held at the Wenner-Gren Center, Stockholm, Sweden, 27-28 October 1980; pp. 3-14.

263. Vest, R.S.; Pike, C.J. Gender, sex steroid hormones, and Alzheimer's disease. Horm Behav. 2013, 63, 301-307. [CrossRef]

264. Lenz, K.M.; McCarthy, M.M. Organized for sex-steroid hormones and the developing hypothalamus. Eur. J. Neurosci. 2010, 32, 2096-2104. [CrossRef]

265. Tchernof, A.; Després, J.P. Sex steroid hormones, sex hormone-binding globulin, and obesity in men and women. Horm. Metab. Res. 2000, 32, 526-536. [CrossRef]

266. Luine, V.N. Sex steroids and cognitive function. J. Neuroendocrinol. 2008, 20, 866-872. [CrossRef]

267. Rubinow, K.B. An intracrine view of sex steroids, immunity, and metabolic regulation. Mol. Metab. 2018, 15, 92-103. [CrossRef] [PubMed]

268. Owens, S.J.; Murphy, C.E.; Purves-Tyson, T.D.; Weickert, T.W.; Weickert, S.C. Considering the role of adolescent sex steroids in schizophrenia. J. Neuroendocrinol. 2018, 30, e12538. [CrossRef] [PubMed]

269. Wang, S.; Dong, G.; Sheng, C. Structural simplification of natural products. Chem. Rev. 2019, 119, 4180-4220. [CrossRef] [PubMed]

270. Nahar, L.; Sarker, S.D. A review on steroid dimers: 2011-2019. Steroids 2020, 164, 108736. [CrossRef]

271. Sahu, P.; Gidwani, B.; Dhongade, H.J. Pharmacological activities of dehydroepiandrosterone: A review. Steroids 2020, $153,108507$. [CrossRef]

272. Biellmann, J.-F. Enantiomeric steroids: synthesis, physical, and biological properties. Chem. Rev. 2003, 103, 2019-2034. [CrossRef]

273. Skoda-Földes, R.; Kollár, L. Transition-metal-catalyzed reactions in steroid synthesis. Chem. Rev. 2003, 103, 4095-4130. [CrossRef]

274. Albano, G.D.; Amico, F.; Cocimano, G.; Liberto, A.; Maglietta, F. Adverse effects of anabolic-androgenic steroids: A literature review. Healthcare 2021, 9, 97. [CrossRef]

275. Pope, H.G., Jr.; Kanayama, G.; Hudson, J.I.; Kaufman, M.J. Anabolic-androgenic steroids, violence, and crime: Two cases and literature review. Am. J. Addict. 2021, 30, 423-432. [CrossRef]

276. Hearne, E.; Wazaify, M.; Van Hout, M.C.; Atkinson, A.; McVeigh, J. Anabolic-androgenic steroid use in the Eastern Mediterranean region: A scoping review of extant empirical literature. Int. J. Ment. Health Addict. 2021, 19, 1162-1189. [CrossRef]

277. Shamsaei, N.; Ahmadian, N. Investigation of psychological relationship between the level of religiosity and doping susceptibility among bodybuilding athletes. Relig. Health Spring Summer 2020, 8, 30-38.

278. Hoseini, M.; Yousefi, B.; Khazaei, A. The prevalence of anabolic-androgenic steroids abuse, knowledge and attitude of their side effects, and attitude toward them among the female bodybuilding athletes in kermanshah. J. Fasa Univ. Med. Sci. 2020, 10, 2436-2446.

279. Murtha, R.; Heffernan, C.; Hunt, T. Definition diets and deteriorating masculinity? Bodybuilding diets in Mid-Century America. Glob. Food Hist. 2021, 7, 71-91. [CrossRef]

280. Okano, M.; Sato, M.; Ikekita, A. Analysis of non-ketoic steroids $17 \alpha$-methylepithiostanol and desoxymethyl-testosterone in dietary supplements. Drug Test. Anal. 2009, 1, 518-525.

281. Akram, O.N.; Bursill, C.; Desai, R.; Heather, A.K.; Kazlauskas, R.; Handelsman, D.J.; Lambert, G. Evaluation of androgenic activity of nutraceutical-derived steroids using mammalian and yeast in vitro androgen bioassays. Anal. Chem. 2011, 83, 2065-2072. [CrossRef]

282. Díaz, F.C.; Sáez-González, E.; Benlloch, S.; Álvarez-Sotomayor, D. Albumin dialysis with MARS for the treatment of anabolic steroid-induced cholestasis. Ann. Hepatol. 2016, 15, 939-943. 
283. Okuno, Y.; Nakabou, Y.; Suzuki, S.; Ichiba, S.; Sugiyama, H. Complete remission by mepitiostane in hypoplastic leukemia. Rinsho Ketsueki 1989, 30, 1280-1283.

284. Komeno, T. Steromal 2,3-Diol Cyclic Trithiocarbonate. U.S. Patent 3,139,128, 30 June 1964.

285. Korneno, T.; Kawanami, E. 11,12-Epithio Steroids of Pregnane Series. U.S. Patent 3160627, 25 December 1964.

286. Komeno, T. 2,3-Epithio-Steroids and Production Thereof. U.S. Patent 3,230,215, 18 January 1966.

287. Klimstra, P.D. Optionally 17-Hydrocarbon (Substituted), 17-Oxygenated-2,3-Epithio-5a-Androstanes. U.S. Patent 3,405,124, 25 December 1968.

288. Hirata, M. Process for Stabilization of a Composition of 2,3-Epithio-Androstanes and Composition Obtained Thereby. U.S. Patent 3,670,080, 13 June 1972.

289. Miyake, T.; Uchida, K.; Kakushi, H.; Nomura, Y.; Kadowaki, M. 2a,3a-epithio-5a-androstan-17b-yl 1-methoxycyclopentyl ether (10361-S), a new orally active anabolic-androgenic steroid. Jpn. J. Pharmacol. 1974, 24, 551-558. [CrossRef]

290. Kurachi, K.; Aono, T.; Tomoyama, J.; Matsumoto, K.; Nakasima, A. Effects of 2,3-epithio-5-androstan-17-ol (epitiostanol) on hypothalamo-pituitary-gonadal axis in humans. Acta Obstet. Gynaecol. Jpn. 1975, 22, 42-48.

291. Li, X.; Rhee, D.K.; Malhotra, R.; Mayeur, C.; Hurst, L.A.; Ager, E. Progesterone receptor membrane component-1 regulates hepcidin biosynthesis. J. Clin. Investig. 2016, 126, 389-401. [CrossRef]

292. Kang, L.; Li, X.Q.; Chen, C.X.; Wang, F.R. Research progress on structure modification and biological activity of $18 \beta$-glycyrrhetinic acid. Curr. Opin. Compl. Alternat. Med. 2014, 1, e00008.

293. Wu, S.; Wang, W.; Dou, J.H. Research progress on the protective effects of licorice-derived 18ß-glycyrrhetinic acid against liver injury. Acta Pharmacol. Sin. 2021, 42, 18-26. [CrossRef]

294. Dembitsky, V.M.; Gloriozova, T.A.; Poroikov, V.V. Pharmacological activities of epithio steroids. J. Pharm. Res. Int. 2017, 18, 1-19. [CrossRef]

295. Huang, M.; Xie, X.; Gong, P.; Wei, Y.; Du, H.; Xu, Y. A 18ß-glycyrrhetinic acid conjugate with Vorinostat degrades HDAC3 and HDAC6 with improved antitumor effects. Eur. J. Med. Chem. 2020, 188, 111991. [CrossRef]

296. Conor, R. Selenium in Food and Health; Springer: Boston, MA, USA, 2006.

297. Kang, D.; Lee, J.; Wu, C. The role of selenium metabolism and selenoproteins in cartilage homeostasis and arthropathies. Exp. Mol. Med. 2020, 52, 1198-1208. [CrossRef]

298. Terry, N.; Zayed, A.M.; De Souza, M.P.; Tarun, A.S. Selenium in higher plants. Ann. Rev. Plant Physiol. Plant Mol. Biol. 2000, 51, 401-432. [CrossRef]

299. Pyrzynska, K.; Sentkowska, A. Selenium in plant foods: Speciation analysis, bioavailability, and factors affecting composition. Crit. Rev. Food Sci. Nutrit. 2021, 61, 1340-1352. [CrossRef]

300. Pilon-Smits, E.A.H. Selenium in plants. Prog. Bot. 2015, 76, 93-106.

301. Nogueira, C.W.; Barbosa, N.V.; Rocha, J.B.T. Toxicology and pharmacology of synthetic organoselenium compounds: An update. Arch. Toxicol 2021, 95, 1179-1226. [CrossRef]

302. Ranu, B.C.; Banerjee, B. Organoselenium Chemistry; De Gruyter: Berlin, Germany; Boston, MA, USA, 2020.

303. Li, Q.S.; Wu, D.M.; Zhu, B.C.; Wang, Y.G. Organic selenium resin in solid phase synthesis and its application in constructing medicinally relevant small organic molecules. Mini Rev. Med. Chem. 2013, 13, 854-869. [CrossRef] [PubMed]

304. Dembitsky, V.M.; Gloriozova, T.A.; Poroikov, V.V. Biological activities of organometalloid (As, At, B, Ge, Si, Se, Te) steroids. J. App Pharm. Sci. 2017, 7, 184-202.

305. Wirth, T. Organoselenium Chemistry: Synthesis and Reactions; John Wiley \& Sons, Inc.: Weinheim, Germany, 2011.

306. Ibrahim-Ouali, M. Total synthesis of steroids and heterosteroids from BISTRO. Steroids 2015, 98, 9-28. [CrossRef] [PubMed]

307. Ibrahim-Ouali, M. First total synthesis of 11-selena steroids. Tetrahedron Lett. 2009, 50, 1607-1609. [CrossRef]

308. Ibrahim-Ouali, M. First total synthesis of 11-tellura steroids. Tetrahedron Lett. 2010, 51, 3610-3612. [CrossRef]

309. Ibrahim-Ouali, M.; Romero, E.; Bouleghlem, H. First total syntheses of ( \pm )-3-aza-11-selena and ( \pm )-3-aza-11-tellura steroids. Tetrahedron 2011, 67, 3668-3676. [CrossRef]

310. Santi, C. Organoselenium Chemistry: Between Synthesis and Biochemistry; Bentham Science Publishers: Sharjah, United Arab Emirates, 2014.

311. Knapp, F.F. The synthesis of 123 Te-labeled $17 \beta$-hydroxy-2-tellura-A-nor-5 $\alpha$-androstane. J. Label. Comp. Radiopharm. 1980, 17, 81-91. [CrossRef]

312. Leimbach, D.; Karls, J.; Guo, Y.; Ahmed, R.; Ballof, J.; Bengtsson, L.; Pamies, F.B.; Borschevsky, A. The electron affinity of astatine. Nat. Commun. 2020, 11, 3824. [CrossRef]

313. Kugler, H.K.; Keller, C. At Astatine; Springer: Berlin/Heidelberg, Germany, 1985.

314. Eychenne, R.; Bouvry, C.; Bourgeois, M.; Loyer, P.; Benoist, E.; Lepareur, N. Overview of radiolabeled somatostatin analogs for cancer imaging and therapy. Molecules 2020, 25, 4012. [CrossRef]

315. Visser, G.W.M.; Diemer, E.L.; Kaspersen, F.M. The preparation of aromatic astatine compounds through aromatic mercury compound's part II: Astatination of pyrimidines and steroids. J. Label. Comp. Radiopharm. 1981, 18, 799-807. [CrossRef]

316. Liu, B.L.; Jin, Y.T.; Liu, Z.H.; Luo, C.; Kojima, M.; Maeda, M. Halogen exchanges using crown ethers: Synthesis and preliminary biodistribution of 6-(211At)-astatomethyl-19-norcholest-5(10)-en-3beta-ol. Int. J. Appl. Radiat. Isot. 1985, 36, 561-563. 